DEPARTMENT OF THE INTERIOR

UNITED STATES GEOLOGICAL SURVEY

CHARLES D. WALCOTT, DIREOTOR

\title{
UNDERGROUND WATERS
}

OF

\section{COASTAL PLAIN OF TEXAS}

BY

THOMAS U. TAYLOR

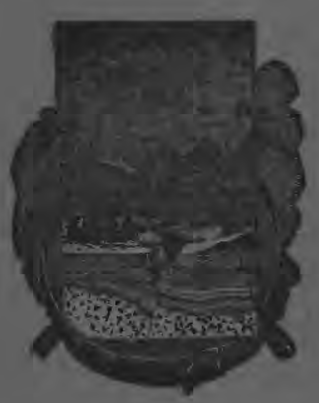

WASHINGTON

GOVERNMENT PRINTING OFFICE

1907 
Water-Smply and Irrigation Paper No. 190 Series 0, Underground Watar, of th DEPARTMENT OF THE INTERIOR UNITED STATES GEOLOGICAL SURVEY CHARLES D. WALCOTT, DIRECTOR

\title{
UNDERGROUND WATERS
}

$\mathrm{OF}$

\section{COASTAL PLAIN OF TEXAS}

\author{
$\mathrm{BY}$ \\ THOMAS U. TAYLOR
}

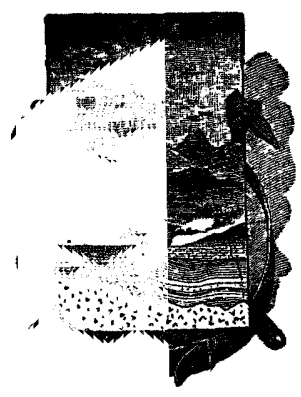

WASHINGTON

GOVERNMENT PRINTING OFFICE

1907

SEP 301907 


\section{CONTENTS.}

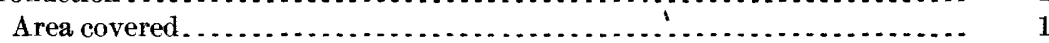

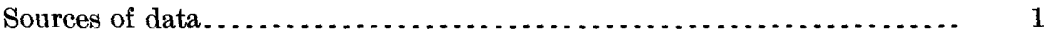

Geography of the region ......................................... 1

General statement................................................. 1

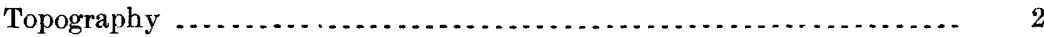

Drainage ................................................... 2

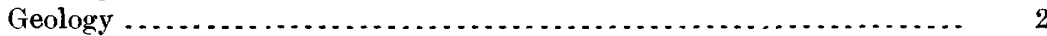

Underground waters, by counties................................. 2

Cameron County ............................................. 3

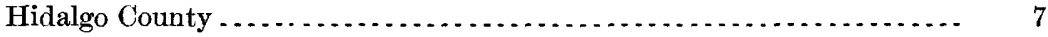

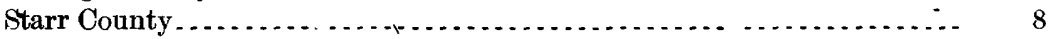

Nueces County ......................................... 9

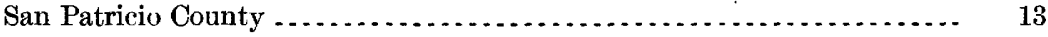

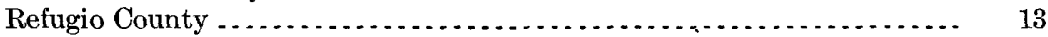

Aransas County .................................................. 14

Calhoun County............................................... 14

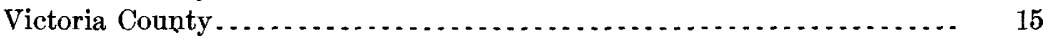

Jackson County .................................................. 16

Matagorda County .............................................. 19

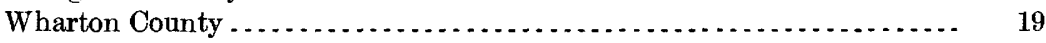

Brazoria County .......................................... 21

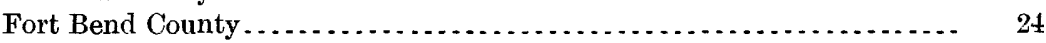

Harris County .............................................. 24

Galveston County .................................................. 27

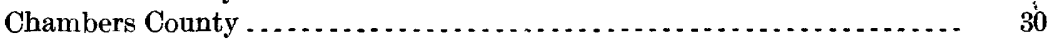

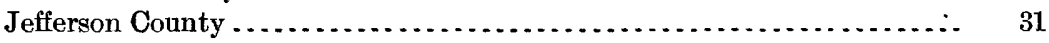

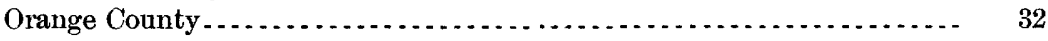

Zapata County ............................................. 33

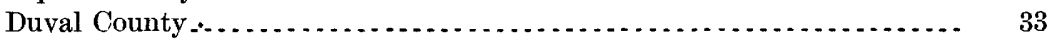

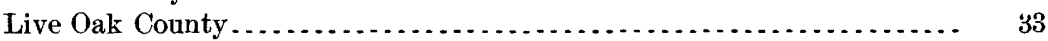

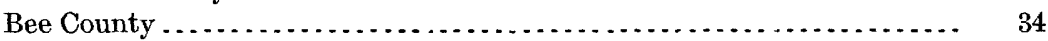

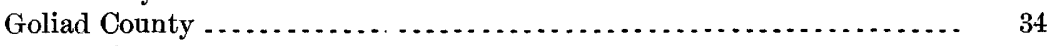

Karnes County.............................................. 34

Dewitt County ................................................. 34

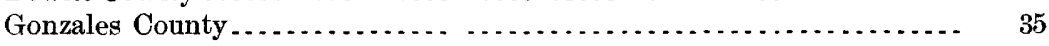

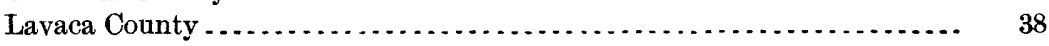

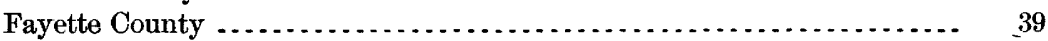

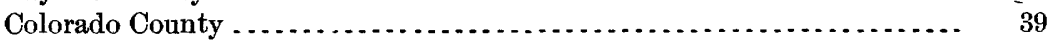

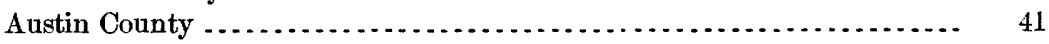

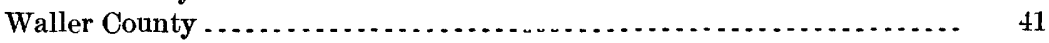

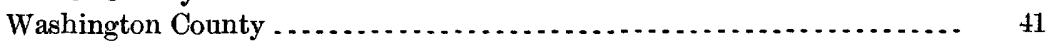

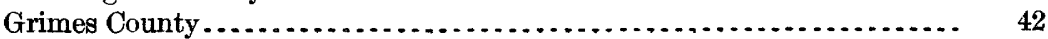


Underground waters, by counties-Continued.

Liberty County

Montgomery County

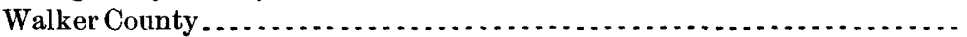

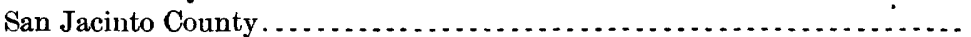

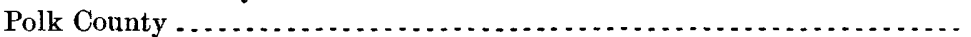

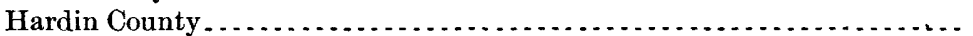

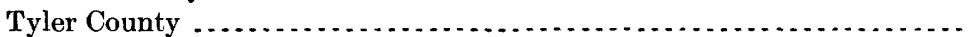

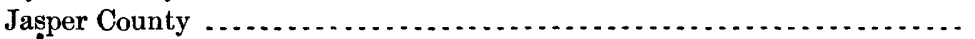

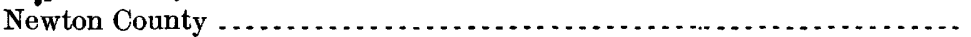

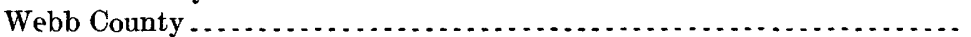

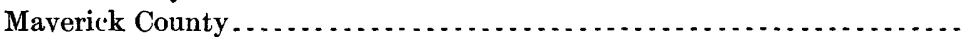

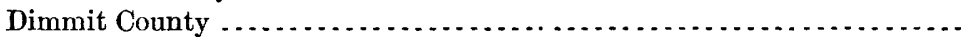

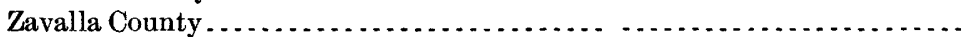

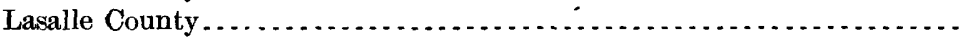

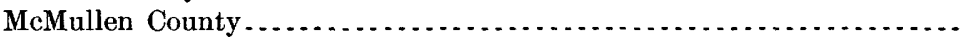

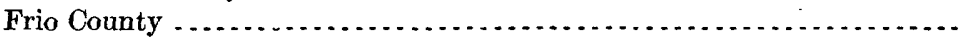

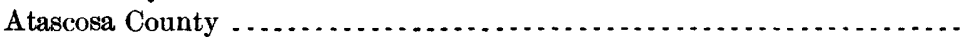

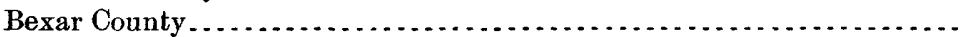

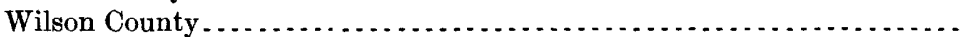

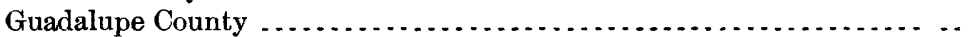

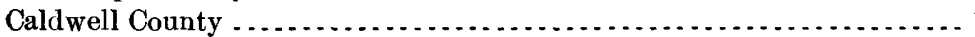

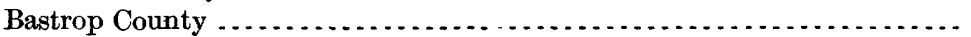

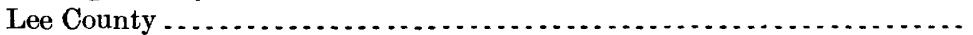

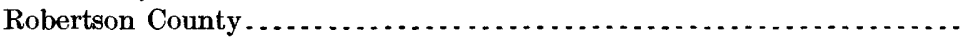

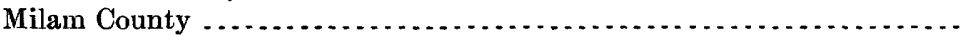

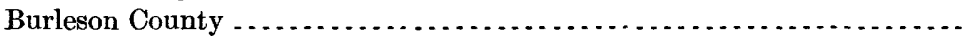

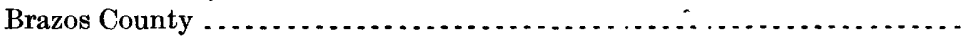

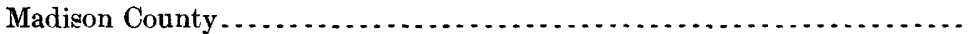

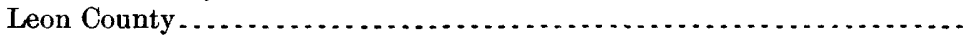

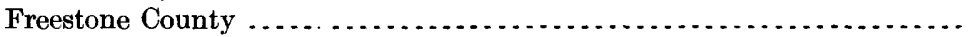

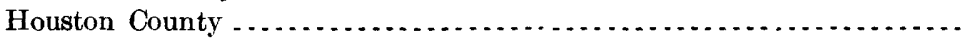

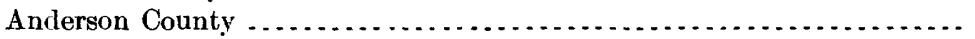

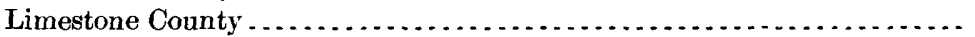

Cherokee, Trinity, Angelina, San Augustine, and Sabine counties........

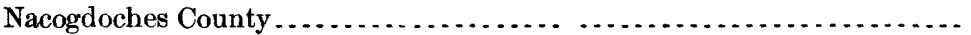

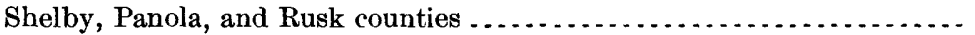

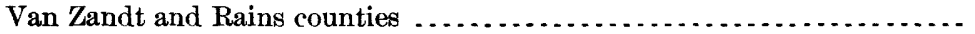

Smith County

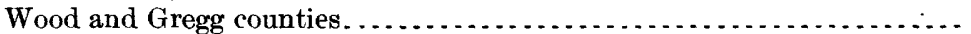

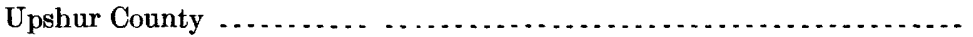

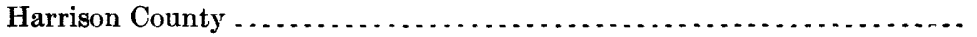

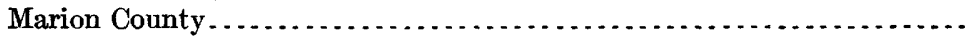

\section{L L USTR A TI I O N S.}

Plate I. A, A typical artesian well in the Texas Coastal Plain; $B$, Artesian well 4 miles south of Pearsall, Tex

II. Map showing location of artesian wells in the Texas Coastal Plain...

III. Artesian wells in Rio Grande embayment. 




\section{UNDERGROUND WATERS OF THE COASTAL PLAIN OF TEXAS.}

By T. U. TAYLOR.

\section{INTRODUCTION.}

Area covered.- The region to which this report relates includes the greater part of the Coastal Plain of Texas. It comprises an area about 150 miles wide, bordering the coast and extending across the entire State. According to R. T. Hill's classification it includes the "eastern" and "southern" provinces, and it is bordered on the west, from Del Rio to Colorado River, by the "Edwards Plateau," and, from the Colorado River to the Arkansas State line, by the "Black Prairie." It includes the district lying between the coast and a line connecting Texarkana with Del Rio, through Cooper, Greenville, Corsicana, Cameron, Elgin, and San Antonio, an area of about 75,000 square miles.

Sources of data.-The information on which this report is based has been obtained partly by personal visits to the various localities and partly by correspondence. Information has been furnished by the following persons: B. M. Haberer, C. F. H. von Blucher, Randolph Robertson, F. W. Simonds, H. W. Harper, Ira H. Evans, Rudolph Kleberg, T. J. Lyne, G. Warnicke, R. D. Parker, O. M. Ball, Garland Miller, A. W. Seeligson, J. B. Armstrong, J. L. Ladd, Travis L. Smith, E. D. Dorchester, Geo. C. Herman, Geo. J. McManus, J. E. Broussard, and J. W. Sanders. The writer is also indebted to Mr. E. T. Dumble, former State geologist of Texas, for much valuable information.

\section{GEOGRAPHY OF THE REGION.}

General statement.-The Coastal Plain of Texas is a continuation of the Atlantic Coastal Plain to the east, although in many features it differs from that area. In general it consists of a gently sloping plain, extending from a high or mountainous background to the Gulf. In the eastern part of Texas the Coastal Plain has the general character seen in other Southern States, but in its southwestern extension it becomes more or less modified, widening to the southwest in the 
vicinity of the Rio Grande where there is a great embayment similar to that of Mississippi River. South of Colorado River there is a welldefined interior border to the Coastal Plain, but to the north of that stream the transition between the level and hilly lands is gradual.

Topography.-The topography of the Texas Coastal Plain presents little variety. The surface rises gradually from the sea level at the coast to an elevation of 800 to 1,000 feet along the interior margin of the province. The portion of the plain bordering the coast is eharacterized by a very level surface which, throughout extensive areas, is scarcely broken, except by a few shallow drainage ways. The highest land along the coast is at Corpus Christi, where the bluffs rise to 40 to 60 feet above sea level. Toward the interior the surface of the plain becomes more diversified, developing into rolling hills which increase in number and prominence toward the western margin of the province.

Drainage.-The Texas Coastal Plain is traversed by many streams. The largest of these are the Neches, Trinity, Brazos, Colorado, and Nueces rivers. Of all these streams only the Brazos enters the Gulf directly, the others emptying into lagoons or bays. South of the Nueces the drainage is not completely developed and the entire area between this stream and the Rio Grande contains only two small creeks, the San Fernando and Olmos, which unite to form Capano Bay. The larger streams of the area are generally narrow and deep, with feeble currents. Near the shore many of them expand into broad, shallow lakes entering the Gulf through shallow bays. While there are many streams in the Texas Coastal Plain, much of its surface is poorly drained, and in places water stands in lakes or ponds throughout the year.

\section{GEOLOGY.}

The Texas Coastal Plain is developed on a great thickness of soft rocks, sands, gravel, clays, and loams in general spread in thin but more or less extensive beds which dip very gently to the east. These sediments have a thickness of sevieral thousand feet and are composed of alternating porous and impervious members, producing ideal artesian conditions. Over the greater part of the area the rocks are of Tertiary age, but along the interior border Upper Cretaceous sediments appear.

\section{UNDERGROUND WATERS, BY COUNTIES.}

General statement.-During recent years the underground-water resources of the Texas Coastal Plain have become of considerable economic importance. Ground water, which is usually abundant throughout the district, has been used for many years for general domestic purposes, and small irrigation plants in a few instances have derived their water supply from this source. Within recent years 


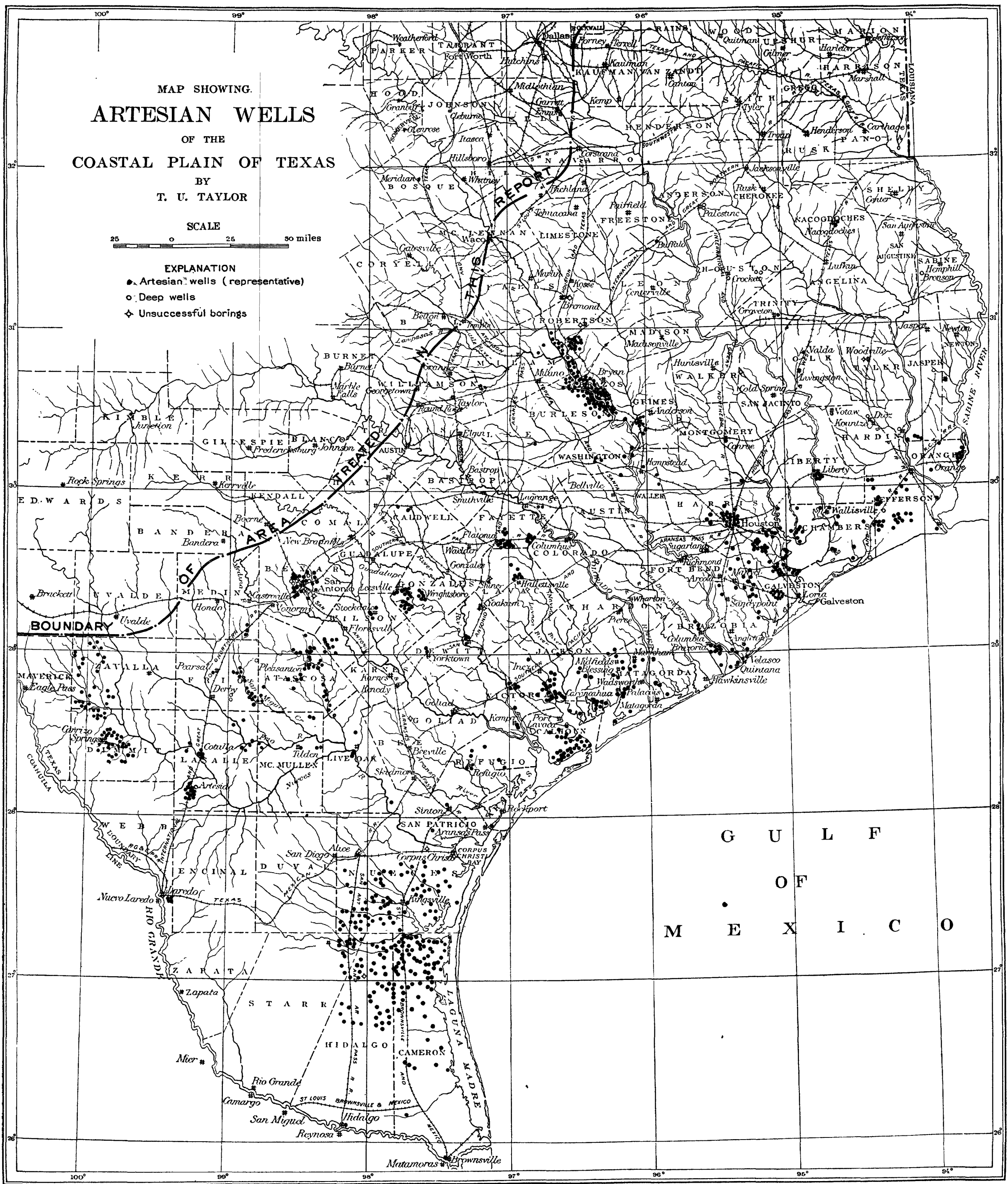

MAP SHOWING LOCATION OF ARTESIAN WELLS IN THE TEXAS COASTAL PLAIN. 
artesian wells have been obtained in various parts of the region. Some of these furnish flows adequate for considerable irrigation. Three of the larger cities in the region, Houston, Galveston, and San Antonio, derive their entire city water supply from artesian sources. At Houston the city water is supplied by 60 flowing wells, while at Galveston and San Antonio 15 and 30 wells, respectively, furnish the required amounts. In the vicinity of El Campo, Chesterville, and East Bernard shallow artesian wells are employed to a considerable extent for rice irrigation, especially where small crops are raised. In the vicinity of Webster, in the southern part of Harris County, the flow of several ordinary surface wells has been increased, by pumping, to such an extent as to furnish water for the irrigation of 60 to 100 acres of rice. The depth at which artesian water may be obtained in the Coastal Plain of Texas varies according to the locality. It ranges from a few feet to over 2,000 feet, but the average is about 600 feet.

The amount of flow of these wells varies from 20 to 1,600 gallons a minute. A typical artesian well of this district is shown in Pl. I. The water is more or less mineralized, but with few exceptions the dissolved salts are neither objectionable for domestic purposes nor deleterious to plant growth. The general distribution of artesian wells of the Coastal Plain of Texas is shown in Pl. II.

In the following discussion the underground-water resources of the region will be described by counties.

\section{CAMERON COUNTY.}

Shallow wells.-The depths of the shallow wells of Cameron County vary from 20 to 100 feet, according to the locality. Along the coast water can usually be procured at depths of 20 to 30 feet, but, owing to the nearness of the sea, it is generally salty. To the north, along the bay, the wells are somewhat deeper, ranging from 20 to 60 feet, and in the western part of the county the deepest wells occur, some exceeding 100 feet. At Brownsville and in the immediate vicinity the average depth of shallow wells is about 30 feet.

Artesian wells. - Artesian water is now obtained in the northern twothirds of this county, at depths which vary from 600 to 1,200 feet. There are about 150 flowing wells in the county. The flows of these wells vary from 50 to 1,000 gallons a minute, the average being about 400 gallons. A group of artesian wells in the Rio Grande embayment is shown in Pl. III (p. 6). The following is a list of artesian wells in Cameron County: 
Artesian wells in Cameron County.

THE KENEDY PASTURE COMPANY'S WELLS.

\begin{tabular}{|c|c|c|c|}
\hline Name. & Driller. & Depth. & $\begin{array}{l}\text { Flow per } \\
\text { minute. }\end{array}$ \\
\hline - & Wm. Turcotte. ............ & Feet. & $\underset{75}{\text { Gallons. }}$ \\
\hline (n, & & 825 & 150 \\
\hline Do.. & do & 890 & 600 \\
\hline San Juan. & 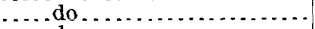 & 1,000 & 250 \\
\hline 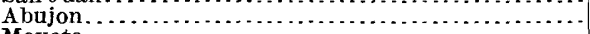 & (n) & 1,030 & 300 \\
\hline Moyote ... & ............... & 610 & 80 \\
\hline 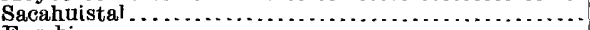 & ............. & 998 & 125 \\
\hline Eurebia................ & $\ldots \ldots . . . . . .$. & 920 & 350 \\
\hline 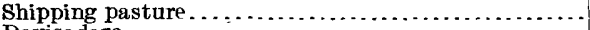 & . . . . . & 689 & 150 \\
\hline 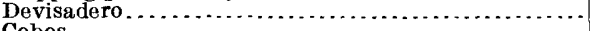 & do & 724 & 550 \\
\hline 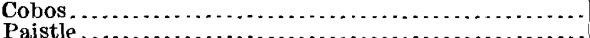 & $\ldots . .$. & 645 & 60 \\
\hline $\begin{array}{l}\text { Paistle } \\
\text { Salada }{ }_{1} \ldots\end{array}$ & do & 710 & $\begin{array}{r}1,000 \\
.600\end{array}$ \\
\hline $\begin{array}{l}\text { Salada } \ldots \ldots \ldots \ldots \ldots \\
\text { Corte Sacate } \ldots \ldots \ldots \ldots \ldots\end{array}$ & & 751 & $\begin{array}{r}600 \\
400\end{array}$ \\
\hline Mota del Diablo............. & do & 1,019 & 500 \\
\hline Atravesada.................. & 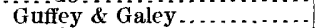 & 720 & 500 \\
\hline Alto & ..................... & 1,120 & 350 \\
\hline Casa Mott . . & White & 1,175 & 500 \\
\hline 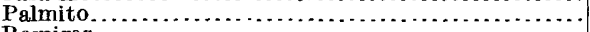 & W. P. Gano.... & 1,035 & 600 \\
\hline Ramirez............... & ... do ...... & 1,123 & 450 \\
\hline Edwin Mallory ............. & ...do. & 1,170 & 500 \\
\hline 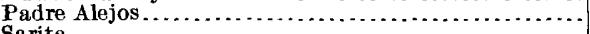 & .......... & 865 & 450 \\
\hline 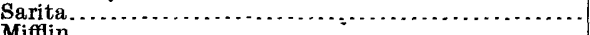 & Railros & 604 & 300 \\
\hline 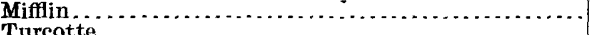 & ite................. & 740 & 450 \\
\hline 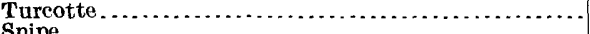 & $\ldots \ldots \ldots \ldots \ldots \ldots$ & 787 & 800 \\
\hline 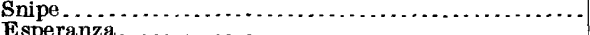 & te.............. & 620 & 700 \\
\hline 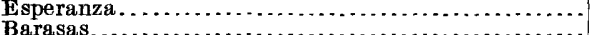 & ... do & 747 & 600 \\
\hline$\cdots \ldots \ldots \ldots \ldots \ldots$ & $d$ & 700 & 500 \\
\hline (n) & $\cdots$ & $61 b$ & $\begin{array}{l}300 \\
450\end{array}$ \\
\hline$\ldots \ldots \ldots$. & do & $\begin{array}{l}602 \\
660\end{array}$ & $\begin{array}{l}400 \\
400\end{array}$ \\
\hline 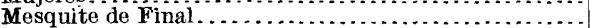 & 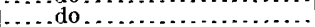 & 750 & 300 \\
\hline & . do & 917 & 200 \\
\hline Tio Coulas... & do & 892 & 250 \\
\hline Tecolite.... & N. G. & 890 & 300 \\
\hline Motto Negra........... & te............ & 1,080 & 250 \\
\hline 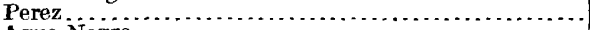 & ............. & 1,360 & 600 \\
\hline Agua Negra............ & W. P. & 1,125 & 550 \\
\hline Mentidua . . . . . . . . . . . & 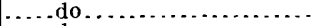 & 1,033 & 500 \\
\hline Mestana................ & - do & 1,232 & 125 \\
\hline 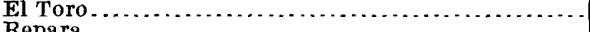 & Wm. I & 1,025 & 350 \\
\hline Repara & 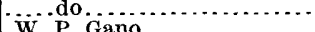 & 1,130 & 300 \\
\hline $\begin{array}{l}\text { Mayote, No. } 2 \ldots \ldots \ldots \ldots \\
\text { San Juan, No. } 2 \ldots \ldots \ldots \ldots\end{array}$ & 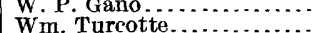 & 1,147 & $\begin{array}{r}700 \\
70\end{array}$ \\
\hline $\begin{array}{l}\text { San Juan, No. 2.. } \\
\text { Tio Martin...... }\end{array}$ & Wm. T & $\begin{array}{l}890 \\
860\end{array}$ & 350 \\
\hline Picacho, No. $2 \ldots \ldots$ & do. & 1,155 & 110 \\
\hline Mesquite................... & ...do. & 750 & 400 \\
\hline ( & .. do. & 617 & 315 \\
\hline Miralejos... & do & 862 & 115 \\
\hline Los Mojaras . . & ...do. & 760 & 450 \\
\hline Pieacho, No. 1 ... & Tom Leary & 1,403 & 600 \\
\hline No name... & $\ldots$ do.... & 1,314 & 350 \\
\hline La Piedra... . & Wm. T & 950 & 350 \\
\hline La Tablome ........... & -do. & 1,000 & 350 \\
\hline Motta Palle ............. & do & (a) & \\
\hline Motta Romendonda... . & $d_{0}$ & 814 & 200 \\
\hline Towrsite, No. 1 ... & W. P. & 807 & 275 \\
\hline Townsite, No. 2. & & 818 & 285 \\
\hline Medeneta.. & $\cdot$ & 1,315 & 400 \\
\hline La Muerta. & & 843 & 300 \\
\hline Bordos $\ldots . .$. & Wm. Turcotte......... & 862 & 160 \\
\hline $\begin{array}{l}\text { Gansos, No. } 1 . \\
\text { Gansos, No.2. }\end{array}$ & W. P. Gano.............. & 1,234 & 350 \\
\hline $\begin{array}{l}\text { Gansos, No. } 2 . \\
\text { El Telephon. }\end{array}$ & & (a) & \\
\hline $\begin{array}{l}\text { El Telephon..... } \\
\text { Railroad (new tr }\end{array}$ & Wm. Turcotte $\ldots \ldots \ldots \ldots$ & 951 & 350 \\
\hline $\begin{array}{l}\text { Railroad (new track) } \\
\text { Loma Prieta.......... }\end{array}$ & $\begin{array}{l}\text { W. P. Gano... } \\
\text { Wm. Turcotte. }\end{array}$ & 803 & 350 \\
\hline ourta Sacate & Win. Turcotte & 757 & 250 \\
\hline
\end{tabular}

$a$ In progress. 
Artesian wells in Cameron County-Continued.

LOWER KING RANCH.

\begin{tabular}{|c|c|c|c|}
\hline Name. & Driller. & Depth. & $\begin{array}{l}\text { Flow per } \\
\text { minute. }\end{array}$ \\
\hline 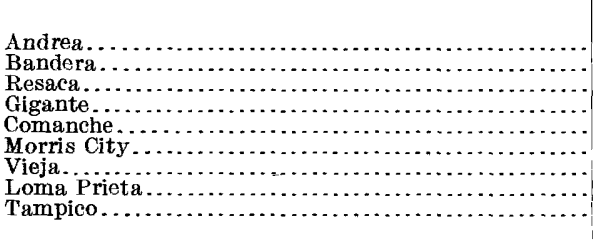 & 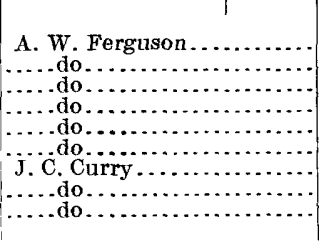 & $\begin{array}{r}\text { Feet. } \\
530 \\
682 \\
747 \\
382 \\
668 \\
1,364 \\
851 \\
838 \\
719\end{array}$ & $\begin{array}{r}\text { Gallons. } \\
70 \\
12 \\
200 \\
75 \\
35 \\
60 \\
300 \\
300 \\
50\end{array}$ \\
\hline
\end{tabular}

MAJ. J. B. ARMSTRONG'S WELLS.

\begin{tabular}{|c|c|c|c|}
\hline 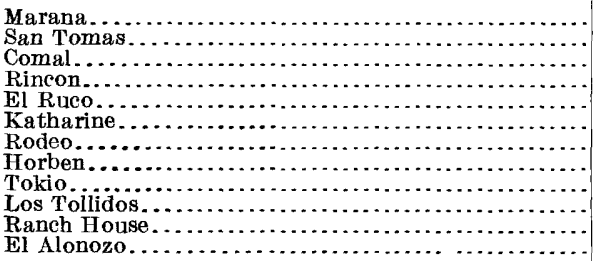 & 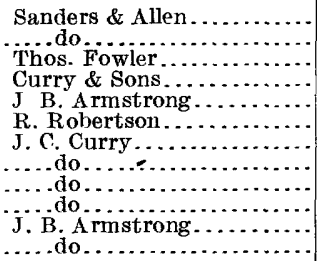 & $\begin{array}{l}490 \\
500 \\
830 \\
770 \\
568 \\
730 \\
805 \\
857 \\
830 \\
780 \\
893 \\
(a)\end{array}$ & $\begin{array}{r}20 \\
20 \\
150 \\
75 \\
76 \\
60 \\
100 \\
150 \\
108 \\
160 \\
150\end{array}$ \\
\hline
\end{tabular}

a In progress.

Record of Atravesada well, on Kenedy ranch, Cameron County.

Surface soil .

Feet.

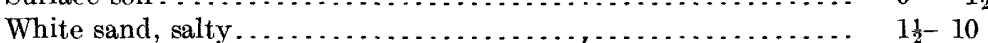

White sand $\ldots \ldots \ldots \ldots \ldots \ldots \ldots \ldots \ldots \ldots \ldots \ldots \ldots \ldots \ldots \ldots \ldots \ldots, 10,35$

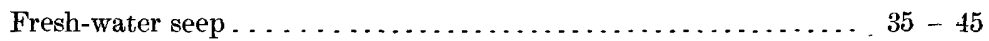

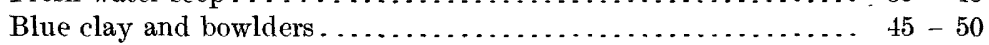

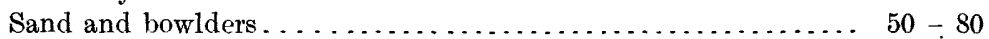

Cemented shells. . . . . . . . . . . . . . . . . . . 82

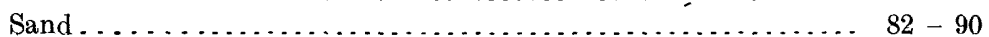

Sand and bowlders. . . . . . . . . . . . . . . . . . . . . . . $90-100$

Cemented shells .................................. $100-103$

Clay bowlders . . . . . . . . . . . . . . . . . . . . . . . . . . . . $103-110$

Blue and brown clay . . . . . . . . . . . . . . . . . . . . . . $110-140$

Brown to buff clay . . . . . . . . . . . . . . . . . . . . . . . $140-265$

Cemented shells, scallop shaped . . . . . . . . . . . . . . . . 265 -320

Brown to buff clay . . . . . . . . . . . . . . . . . . . . . . $320-330$

Soft sand rock .................................... $330-335$

Hard sand rock . . . . . . . . . . . . . . . . . . . . . . . . . . $335-360$

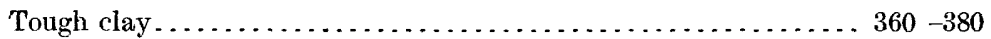

Hard rock....................................... $380-380 \frac{1}{2}$

Clay .......................................... $380 \frac{1}{2}-400$

Hard rock. . . . . . . . . . . . . . . . . . . . . . . . . . . $400-400 \frac{1}{2}$

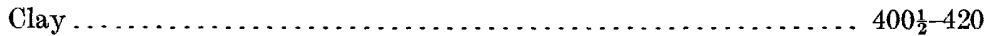

Rock. . . . . . . . . . . . . . . . . . . . . . . . . . . . . 420 422

Clay ........................................ $422-440$

Rock . . . . . . . . . . . . . . . . . . . . . . . . . . . $440-440 \frac{1}{2}$

Fine-grained bluish rock . . . . . . . . . . . . . . . . . . . . . . . . 440 40

Stiff brownish clay . . . . . . . . . . . . . . . . . . . . . $460-470$

Light-brown clay and sand . . . . . . . . . . . . . . . . . $470-555$

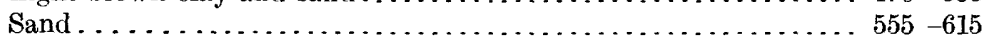




\begin{tabular}{|c|c|}
\hline & Feet. \\
\hline Very hard gumbo.. & $615-\quad 640$ \\
\hline Reddish gumbo... & $640-694$ \\
\hline Rock........ & $694-696$ \\
\hline Clay $\ldots \ldots \ldots \ldots \ldots \ldots \ldots \ldots$ & $696-700$ \\
\hline Water-bearing sand; strong flow..... & $700-$ \\
\hline 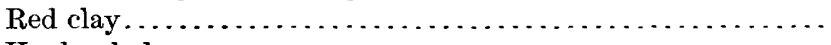 & $720-$ \\
\hline 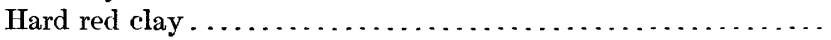 & $765-860$ \\
\hline
\end{tabular}

\section{Record of well at Sauz ranch, Cameron County.}

Pale-red, sandy clay ............................... $\quad{ }^{0} \quad 15$

Sand.......................................... $15-30$

Very pale-red clay, sandy $\ldots \ldots \ldots \ldots \ldots \ldots \ldots \ldots \ldots \ldots . \quad 30-\quad 50$

Sand containing hard layers ....................... $50-\quad 250$

Sand with very soft blue clay $\ldots \ldots \ldots \ldots \ldots \ldots \ldots \ldots \ldots \ldots .250-315$

Sand and bluish clay $\ldots \ldots \ldots \ldots \ldots \ldots \ldots \ldots \ldots \ldots \ldots . .315-\quad 500$

Sandstone....................................... 500 512

Yellow sand................................... 512- 517

Sandstone..................................... $517-525$

Sand.......................................... $525-529$

Very hard bluish rock . . . . . . . . . . . . . . . . . . . . . . $529-699$

Rock and clay .................................. $699-729$

Red and blue clay with hard layers ................... $729-899$

Bluish clay with red layers . . . . . . . . . . . . . . . . . . . . . $\quad 899-989$

Reddish and greenish clay . . . . . . . . . . . . . . . . . .

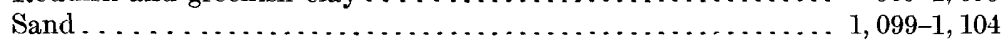

Record of Ovejas well, 8 miles east of Sauz ranch, Cameron County.

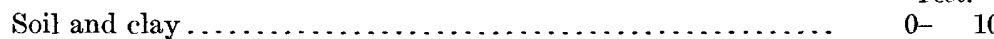

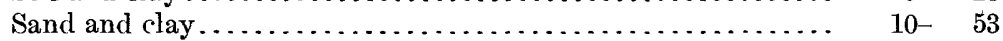

Clay and sand in hard and soft layers . . . . . . . . $68 \ldots \ldots .63$

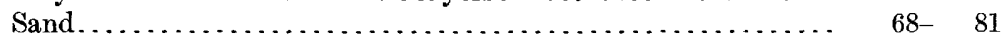

White clay and gravels (" Equus beds") ................ $81-115$

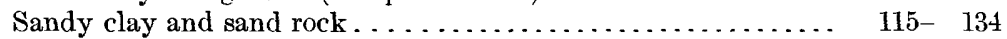

Sand and sandstone................................. $134-185$

Clay and sandstone $\ldots \ldots \ldots \ldots \ldots \ldots \ldots \ldots \ldots \ldots \ldots \ldots \ldots, 185-208$

Sand ........................................ 208 225

Blue clay ....................................... 225- 278

Sand ........................................... $278-290$

Sand and sandstone.................................. $290-378$

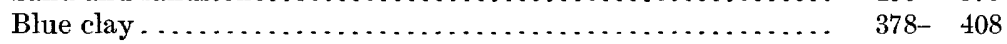

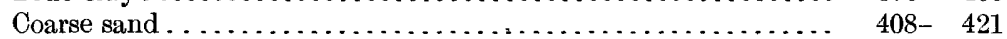

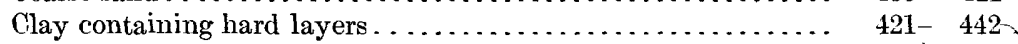

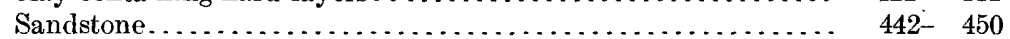

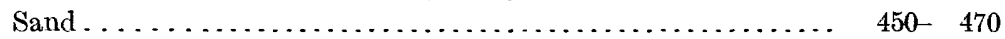

- White clay .................................. $470-476$

Sand ......................................... $476-490$

Bluish clay ................................ 490 $\quad 520$

Sand and sandstone................................... $520-532$

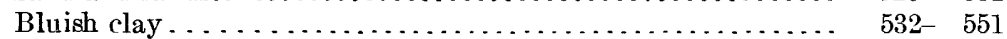

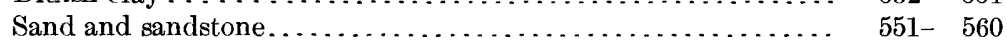

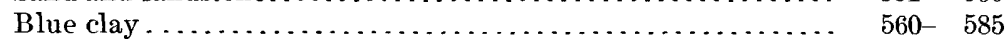

Sandy clay ........................................ $585-596$

Very fine sand . . . . . . . . . . . . . . . . . . . . . . . . . . 513

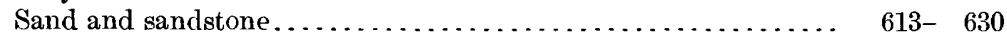


U. S. GEOLOGICAL SURVEY
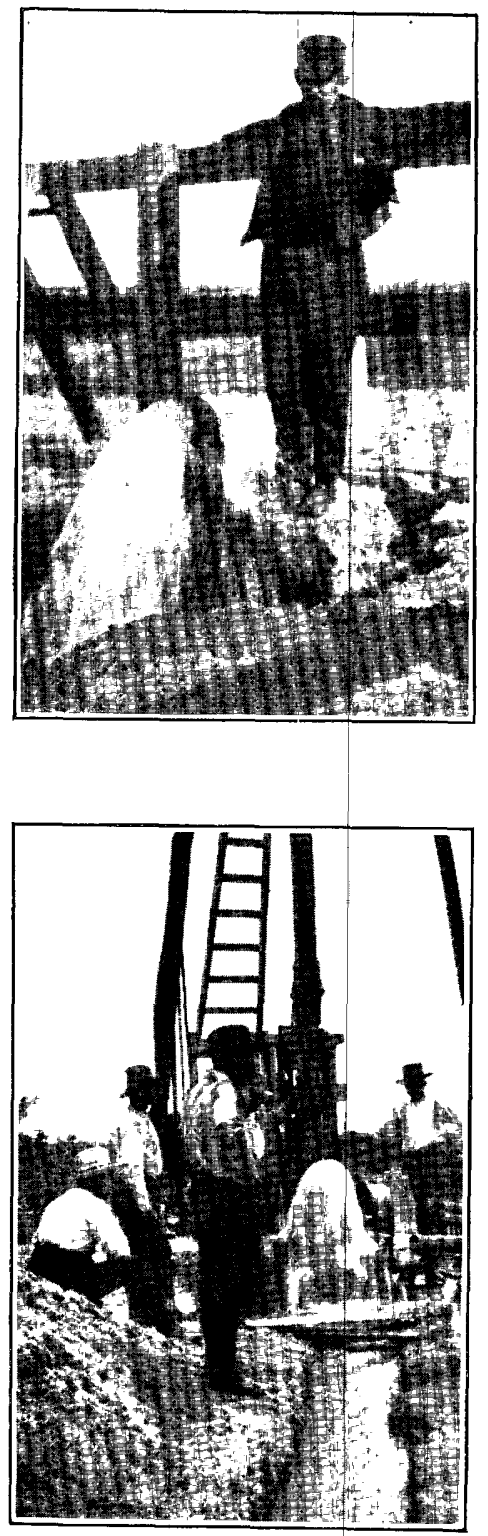

WATER-SUPPLY PAPER NO. 190 PL. III
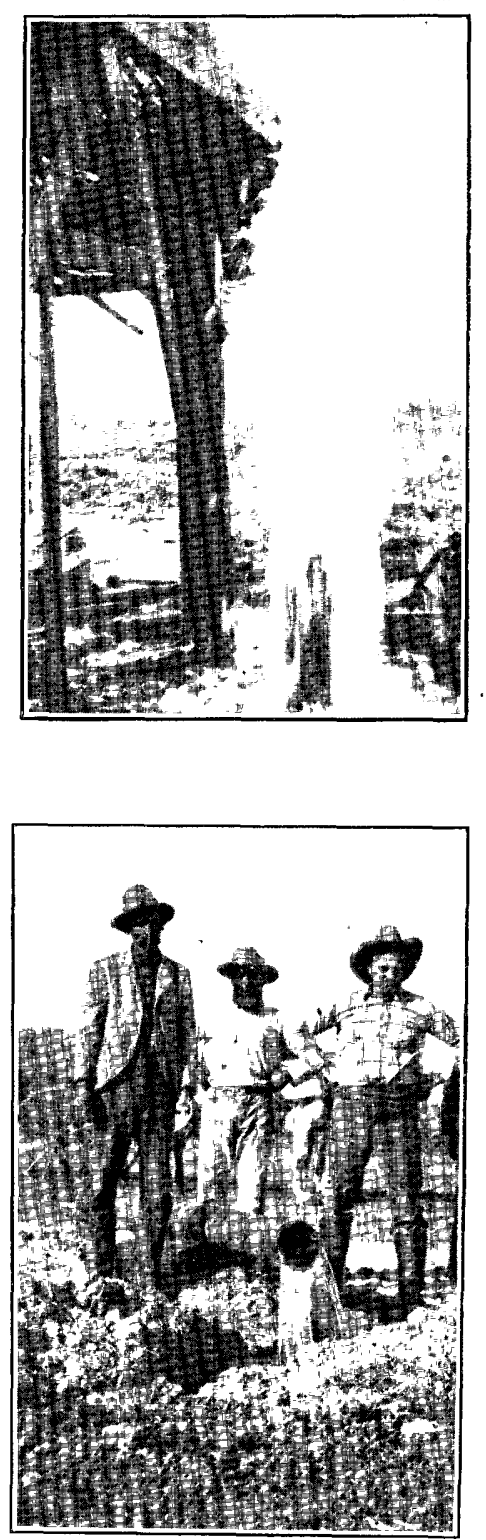

ARTESIAN WELLS IN RIO GRANDE EMBAYMENT. 


\section{HIDALGO COUNTY.}

Shallow wells. - Water is procured from wells in Hidalgo County at depths varying from 25 feet on the lower ground to 150 feet on the highlands. An abundant supply is usually obtained.

Artesian wells.-During the last few years many successful artesian wells have been bored in the northern half of Hidalgo County. These are located mainly on the Lasater, Sullivan, Armstrong, Ward \& Russell, and King ranches. In January, 1906, information had been obtained of about 60 of these wells, but there are others about whicn no data are available. The following is a partial list of the wells, giving their depth and approximate flow.

Artesian wells in northern Hidalgo County.

ED. C. LASATER RANCH.

\begin{tabular}{|c|c|c|c|}
\hline Name. & Driller. & Depth. & $\begin{array}{l}\text { Flow per } \\
\text { minute, }\end{array}$ \\
\hline 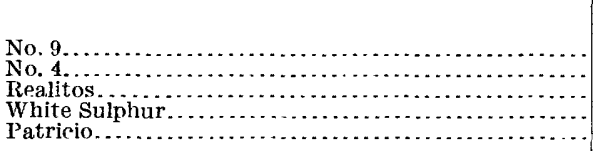 & 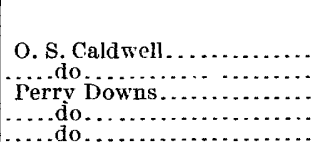 & \begin{tabular}{r|} 
Feet. \\
460 \\
438 \\
478 \\
484 \\
460
\end{tabular} & $\begin{array}{r}\text { Gallons, } \\
10 \\
35 \\
75 \\
75 \\
25\end{array}$ \\
\hline
\end{tabular}

D. STILLIVAN RANCH.

\begin{tabular}{|c|c|c|c|}
\hline Jan Twins. . & s. A. Hamlin............ & 742 & 400 \\
\hline Do & 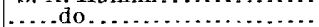 & 1.008 & 600 \\
\hline 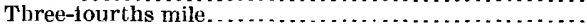 & ... do......................... & 820 & $\$ 00$ \\
\hline Tula Twin. . . & .... do. & 630 & 300 \\
\hline 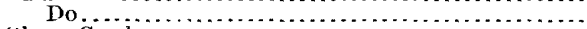 & ..... do.... & 630 & 400 \\
\hline 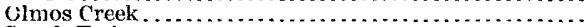 & .....do..... & 350 & 500 \\
\hline 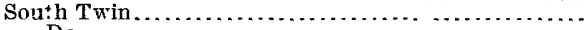 & .... do .................... & 530 & 200 \\
\hline 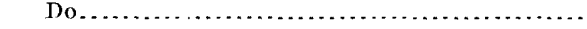 & $\ldots \ldots$ do $\ldots \ldots \ldots \ldots \ldots \ldots \ldots$ & 530 & 150 \\
\hline
\end{tabular}

WARD \& RUSSELL RANCH.

\begin{tabular}{|c|c|c|c|}
\hline 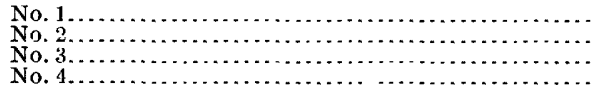 & 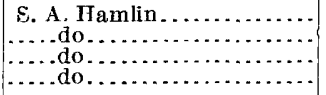 & $\begin{array}{l} \pm 500 \\
\pm 500 \\
\pm 500 \\
1,008\end{array}$ & $\begin{array}{l}\text { Flows. } \\
\text { Do. } \\
\text { Do. } \\
\text { Do. }\end{array}$ \\
\hline
\end{tabular}

KING RANCH.

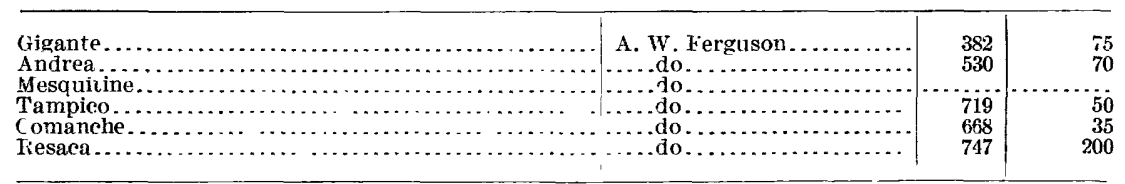


A chemical analysis of the water of the White Sulphur well (Lasater ranch) is given below:

Analysus of water from White Sulphur well, Lasater ranch, Hidalgo County. ${ }^{a}$

\begin{tabular}{|c|c|c|c|}
\hline \multicolumn{2}{|c|}{ Parts per million. } & \multicolumn{2}{|c|}{ Parts per million. } \\
\hline Ammonium $\left(\mathrm{NH}_{4}\right) \ldots \ldots \ldots \ldots$ & 0.04 & Total solids at $105^{\circ} \ldots \ldots \ldots \ldots$. & $1,090.00$ \\
\hline Sodium $(\mathrm{Na}), \ldots \ldots \ldots \ldots \ldots$ & 260.00 & Total solids ignited, dull red- & \\
\hline Magnesium (Mg). . & 29.00 & ness...................... & $1,000.00$ \\
\hline Calcium (Ca).... & 75.00 & Loss on ignition............... & 90.00 \\
\hline Iron $(\mathrm{Fe}) \ldots \ldots \ldots \ldots \ldots \ldots$ & 2. 60 & Albuminoid ammonia $\left(\mathrm{NH}_{3}\right)$.. & .01 \\
\hline Chlorine $(\mathrm{Cl}) \ldots \ldots \ldots \ldots \ldots$ & 380.00 & Free ammonia $\left(\mathrm{NH}_{3}\right) \ldots \ldots \ldots$ & .023 \\
\hline Nitrate radicle $\left(\mathrm{NO}_{3}\right) \ldots \ldots \ldots$ & .02 & Nitrites................. & .007 \\
\hline Sulphate radicle $\left(\mathrm{SO}_{4}\right) \ldots \ldots \ldots$ & 170.00 & Oxygen required....... & 4. 500 \\
\hline Bicarbonate radicle $\left(\mathrm{H}\left(\mathrm{O}_{3}\right) \ldots\right.$ & 120.00 & Temporary hardness.... & 140.00 \\
\hline Silica $\left(\mathrm{SiO}_{2}\right) \ldots \ldots \ldots \ldots \ldots$ & 36.00 & Permanent hardness......... . & 68.00 \\
\hline Organic matter.............. & 12.00 & & \\
\hline & 4 & & \\
\hline
\end{tabular}

\section{STARR COUNTY.}

Shallow wells.-Water is generally obtained at shallow depths throughout Starr County, but along the Rio Grande a large portion of the inhabitants use river water.

Artesian wells.-Artesian water is found in the northeastern part of the county, near the town of Falfurrias. The wells range in depth from 540 to 1,020 feet. In the deeper borings five distinct water horizons are encountered, some of which have a capacity of 250 gallons a minute. The water is used extensively for irrigation; and during the last two years the progress in artesian irrigation has been very rapid. The following is a list of wells in Starr County:

Artesian wells in Starr County.

\begin{tabular}{|c|c|c|c|c|c|}
\hline Name. & Depth. & $\begin{array}{l}\text { Flow per } \\
\text { minute. }\end{array}$ & Name. & Depth. & $\begin{array}{l}\text { Flow per } \\
\text { minute. }\end{array}$ \\
\hline 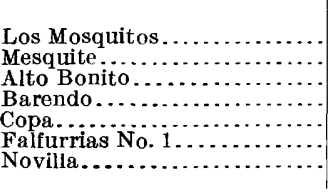 & $\begin{array}{r}\text { Feet. } \\
710 \\
540 \\
562 \\
526 \\
603 \\
800 \\
760\end{array}$ & $\begin{array}{r}\text { Gallons. } \\
25 \\
100 \\
250 \\
30 \\
30 \\
15 \\
75\end{array}$ & 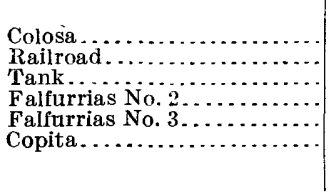 & $\begin{array}{r}\text { Fect. } \\
669 \\
810 \\
756 \\
1,020 \\
700 \\
664\end{array}$ & $\begin{array}{r}\text { Gallons. } \\
100 \\
150 \\
100 \\
80 \\
110 \\
75 \\
\cdot .\end{array}$ \\
\hline
\end{tabular}

a Analysis by H. W. Harper and 13. 1. Glascock, school of chenistry, University of Texas, Austin, April, 1903. 
An analysis of the water from the Mesquite well is given below:

Analysis of water from Mesquite well, Lasater ranch, Starr County.a

\begin{tabular}{|c|c|c|}
\hline \multicolumn{2}{|c|}{ Parts per million. } & Parts per million. \\
\hline Ammonium $\left(\mathrm{NH}_{4}\right) \ldots \ldots \ldots \ldots$ & 0.07 & Total solids at $105^{\circ} \ldots \ldots \ldots \ldots \ldots 60$ \\
\hline Sodium $(\mathrm{Na}) \ldots \ldots \ldots \ldots \ldots$ & 170.00 & Total solids ignited, dull redness. 610 \\
\hline Magnesium $(\mathrm{Mg}) \ldots \ldots \ldots \ldots \ldots$ & .3 & Loss on ignition . . . . . . . . . . . . . . \\
\hline Calcium $(\mathrm{Ca}) \ldots \ldots \ldots \ldots \ldots$. & 38.00 & Albuminoid ammonia $\left(\mathrm{NH}_{3}\right) \ldots$ \\
\hline $\operatorname{Iron}(\mathrm{Fe}) \ldots . .$. & .1 & Free ammonia $\left(\mathrm{NH}_{3}\right) \ldots \ldots \ldots \ldots$ \\
\hline Chlorine (Cl) $\ldots \ldots \ldots$. . & .4 & Oxygen required. . . . . . . . . . 16 \\
\hline Nitrate radicle $\left(\mathrm{NO}_{3}\right) \ldots \ldots \ldots \ldots$ & None. & Temporary hardness. . . . . . . . . 230 \\
\hline Sulphate radicle $\left(\mathrm{SO}_{4}\right) \ldots \ldots \ldots$ & 39.00 & Permanent hardness......... 19 \\
\hline Bicarbonate radicle $\left(\mathrm{HCO}_{3}\right) \ldots$ & 150.00 & \\
\hline Silica $\left(\mathrm{SiO}_{2}\right) \quad \ldots \ldots \ldots \ldots \ldots$. & 18.00 & \\
\hline Organic matter $. . . \ldots \ldots \ldots \ldots . .$. & 44.00 & \\
\hline & & \\
\hline
\end{tabular}

\section{NUECES COUN'TY.}

Shallow wells.-At most places throughout Nueces County water can be obtained at depths of 30 to 40 feet, but in the southern part of the county many of the shallow wells furnish brackish water. There are wells in the northern part of the county which range in depth from 50 to 180 feet. The deepest of these penetrated a water-bearing sand which furnishes 60 gallons of water a minute. Throughout the eastern part of the county water is obtained at a depth of 35 to 40 feet, but much of it is saline. Along the west side of the county the wells 80 feet deep supply only a small amount of water, while those which have been bored to a depth of 150 feet afford an abundance, and in many of them the water rises to within 70 feet of the surface.

Artesian wells.-Artesian water is secured throughout the southern two-thirds of this county at depths which vary from 490 to 1,240 feet. In the amount of flow these wells range from a few gallons to over 600 gallons a minute. So far no flowing wells have been obtained north of the Texas and Mexico Railroad, although borings have been made at Alice, Robstown, and Corpus Christi. The northernmost of the successful wells in this county are on the Driscoll ranch. A list of the artesian wells, giving their depth, flow, and other data, follows.

a Analysis by H. W. Harper and C. Hartmann, sehool of chemistry, University of Texas, Austin, April, 1903. 
Artesian wells in Nueces County.

KING'S WELLS.

\begin{tabular}{|c|c|c|c|}
\hline Name. & Driller. & Depth. & $\begin{array}{c}\text { Flow per } \\
\text { minute. }\end{array}$ \\
\hline Palo Alto No. 1 & & Feet. & Gallons. \\
\hline Palo Alto No. $2 . \ldots . . .$. & 1. Herrmg. & $\begin{array}{l}502 \\
704\end{array}$ & 20 \\
\hline 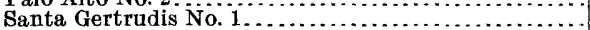 & & 535 & 125 \\
\hline Parrita $\ldots \ldots \ldots \ldots \ldots$ & ............. & 470 & 350 \\
\hline Ebanito No. 1 . & . . . & 456 & 250 \\
\hline Ebanito No. 2... & . & 475 & 100 \\
\hline (......................... & ........... & 396 & 100 \\
\hline . & do & 402 & 225 \\
\hline 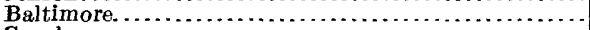 & do & 474 & 110 \\
\hline 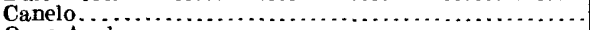 & do & $49 \overline{5}$ & 250 \\
\hline$\ldots \ldots \ldots \ldots \ldots \ldots \ldots \ldots$ & $\ldots \ldots \ldots . . . . .$. & 590 & 40 \\
\hline Lower Little Pasture . . . . . . . . . . . . . . . . . . . . & . . . . . . . & 545 & 50 \\
\hline Santa Gertrudis No. 2 . . . . . . . . . . . . . . . . . . & $\ldots \ldots \ldots \ldots . . .6$ & 550 & 75 \\
\hline 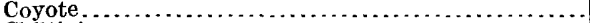 & 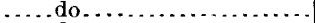 & 795 & 30 \\
\hline 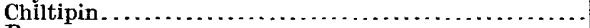 & $\ldots \ldots \ldots \ldots \ldots \ldots$ & 840 & 25 \\
\hline Burro . . & do & 928 & 300 \\
\hline 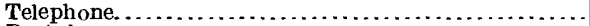 &. do & 874 & 75 \\
\hline$\ldots \ldots \ldots \ldots \ldots \ldots \ldots$ & do & 1,085 & 100 \\
\hline 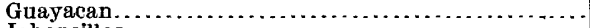 & $\ldots \ldots \ldots$. & 905 & 100 \\
\hline Jaboncillos . . . . . . . . . . . & $\ldots \ldots \ldots \ldots$ & 948 & 60 \\
\hline Rincon de Los Cabellos . ............................ & King Machinery Co. ........ & 764 & 400 \\
\hline 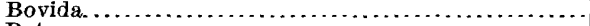 & 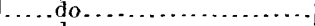 & 720 & 300 \\
\hline & . $\ldots \ldots \ldots \ldots \ldots \ldots$ & 447 & 30 \\
\hline 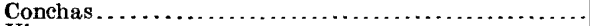 & $\ldots \ldots \ldots . . . .$. & 427 & 30 \\
\hline 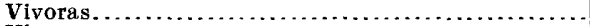 & . do & 989 & 10 \\
\hline Visnaga.. & .....do_... & 913 & 40 \\
\hline Santa Gertrudis No. 3... & A. W. Fergus & 565 & 160 \\
\hline Santa Gertrudis No. 4..... & $\ldots$. . do....... & 560 & 100 \\
\hline 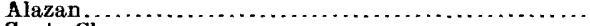 & ..... do & 423 & 40 \\
\hline Santa Clara . . . . . . . . . . . . . . . . . . . . . . & -....do..................... & 525 & 400 \\
\hline 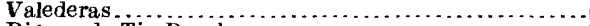 & Tom Leary ................ & 591 & 400 \\
\hline 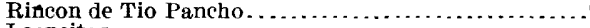 & $\ldots$. do..................... & 615 & 400 \\
\hline Leoncitas............... . & .. do & 570 & 250 \\
\hline 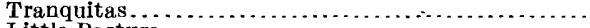 & ... do & 655 & 50 \\
\hline Little Pasture . . . . & $\ldots . .$. & 574 & 60 \\
\hline 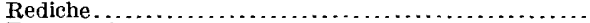 & ..... & 680 & 200 \\
\hline$\ldots \ldots \ldots \ldots \ldots \ldots \ldots \ldots \ldots \ldots \ldots$ & $\ldots \ldots$. & 640 & 150 \\
\hline 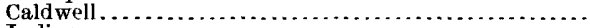 & - do & 540 & 150 \\
\hline 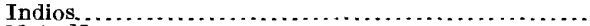 & . do & 480 & 100 \\
\hline Mota Negra... & do & 550 & 25 \\
\hline$\ldots \ldots \ldots \ldots \ldots \ldots \ldots \ldots \ldots$ & do & 700 & 5 \\
\hline 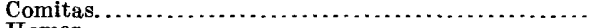 & & 578 & 300 \\
\hline 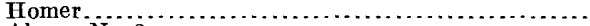 & A. B. Fuller. & 506 & 50 \\
\hline Alazan No. 2.. & King Machine & 465 & 90 \\
\hline 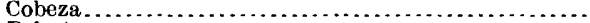 & ..... do. & 410 & 60 \\
\hline 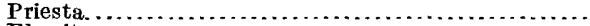 & . do & 635 & 100 \\
\hline Ebenito......... & do & 397 & 25 \\
\hline Leoncitas No. 2. & do. & 1,050 & 75 \\
\hline Herring . . . . . . . . & T. Herring. . & 805 & 20 \\
\hline$\ldots \ldots \ldots \ldots$ & J. P. Morris. & 630 & 50 \\
\hline$\ldots \ldots \ldots \ldots \ldots \ldots$ & T. Her ring. . . & 620 & 40 \\
\hline 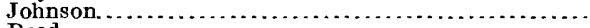 & J. P. Morris. . & 626 & 40 \\
\hline 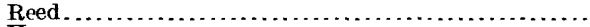 & T. Herring ... & $616^{2}$ & 70 \\
\hline Harper. . . . . . . . . . . . . & R. J. Mills & 625 & 100 \\
\hline Kings ville... & R. Robertson. . . . . . . . & 609 & 75 \\
\hline Simms...... & W. J. House................ . & 600 & 34 \\
\hline MeNeil.. & T. Herring . . . . . . . . & 610 & 75 \\
\hline$\ldots \ldots \ldots \ldots \ldots \ldots \ldots \ldots \ldots$ & A. B. Fuller. . . . . . . & 628 & 110 \\
\hline Huffiman ................... & T. Herring. . . . . . . . . . . . . & 630 & 66 \\
\hline$\ldots \ldots \ldots \ldots \ldots \ldots \ldots$ & J. P. Morris........... & 640 & \\
\hline Weir.... & W. J. House........... & $(a)$ & \\
\hline vey $\ldots . . . . . . . . .$. & T. Herring . . . . . . . . . & 632 & 100 \\
\hline Hoffman. & - & 626 & 75 \\
\hline & & & \\
\hline Penn....................... & W. J. House................ & 650 & 150 \\
\hline Santa Gertrudis No. $5 .$. & King Machinery Co.......... & 580 & 40 \\
\hline
\end{tabular}

a In progress. 
Artesian wells in Nueces County-Continued.

SEELIGSON'S WELLS.

\begin{tabular}{|c|c|c|c|}
\hline Name. & Driller. & Depth. & $\begin{array}{l}\text { Flow per } \\
\text { minute. }\end{array}$ \\
\hline 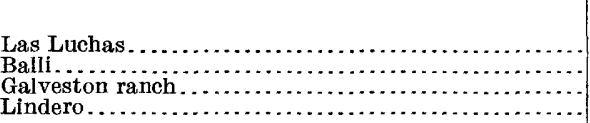 & 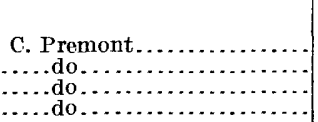 & $\begin{array}{r}\text { Feet. } \\
464 \\
633 \\
630 \\
475\end{array}$ & $\begin{array}{r}\text { Gallons. } \\
50 \\
65 \\
8 \\
75\end{array}$ \\
\hline
\end{tabular}

ANNA COLLINS'S WELLS.

\begin{tabular}{|c|c|c|c|}
\hline 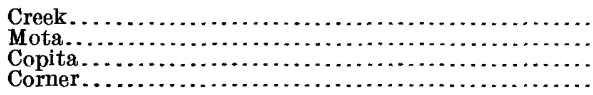 & 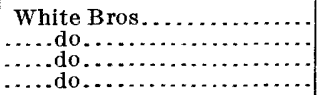 & $\begin{array}{l}625 \\
825 \\
918 \\
790\end{array}$ & $\begin{array}{r}50 \\
9 \\
150 \\
50\end{array}$ \\
\hline
\end{tabular}

ROBERT DRISCOLL'S WELLS.

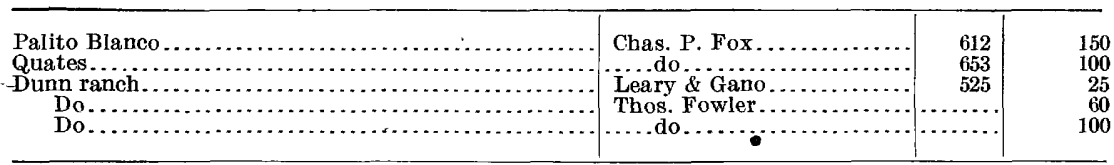

ANDRES CANALES'S WELLS.

\begin{tabular}{|c|c|c|c|}
\hline 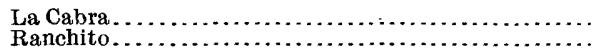 & 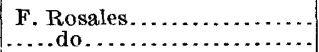 & $\begin{array}{l}440 \\
458\end{array}$ & $\begin{array}{l}80 \\
80\end{array}$ \\
\hline
\end{tabular}

CHARLES WEIL'S WELL.

\begin{tabular}{|c|c|c|c|}
\hline Flowing well ............ & Leary \& Gano............. & 558 & 35 \\
\hline
\end{tabular}

RAGLAND \& HERRING'S WELLS.

Flowing well $\ldots \ldots \ldots \ldots \ldots \ldots \ldots \ldots \ldots \ldots \ldots \ldots \ldots \ldots \ldots \ldots \ldots \ldots \ldots$
Do $\ldots \ldots \ldots \ldots \ldots \ldots \ldots \ldots \ldots$

TEXAS LAND AND CATTLE COMPANY'S LAURELES RANCH WELLS.

\begin{tabular}{|c|c|c|c|}
\hline Shipping Pasture...... & O. S. Caldwell........... & 1,130 & 40 \\
\hline San Vicente.............. & ....do................... & 926 & 30 \\
\hline Santa Cruz.. & $\ldots$. do $\ldots . . . . . . . . .$. & 1,068 & 160 \\
\hline 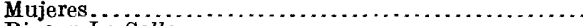 & J. McAlester. . . . . . . . . . . . . & 1,020 & 120 \\
\hline 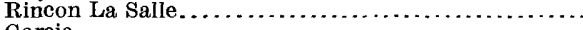 & .... do ..................... & 1,240 & 240 \\
\hline 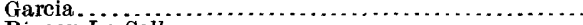 & . . . do . .................... & 1,150 & 25 \\
\hline Rincon La Salle. . . . . . . . & ....do....... & 1,185 & 60 \\
\hline 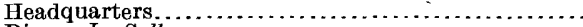 & ....do................. & 998 & 80 \\
\hline Rincon La Salle.................... & $\ldots$...do...... & 1,295 & 35 \\
\hline
\end{tabular}


Record of Galveston well, Seeligson ranch, about 30 miles south of Alice, Nueces Coun ty

Light-colored clay -

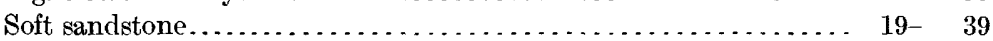

Very hard, white flinty rock....................... $39-119$

Pink to yellowish clay .............................. 119- 199

Reddish clay mixed with bowlders................... 199- 359

Coarse gray sand .................................. 359- 404

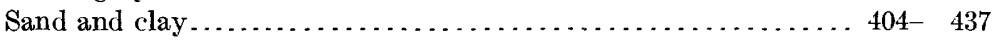

Sand and coarse gravel.......................... 437- 453

Sand and clay .................................. $453-549$

Sand and gravel................................... 549- 569

Rock and sand in alternate layers................... 569- 589

Sand mixed with small pebbles..................... 589- 610

Fine-grained gray sand (water bearing, 10 gallons per minute) .... 610- 631

White calcareous clay .............................. $631-686$

Hard clay containing bowlders.................... 686- 736

Gray sandstone................................ $736-756$

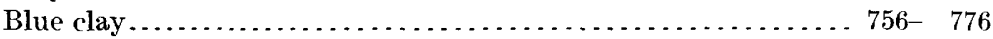

Blue clay with yellow spots.......................... $776-816$

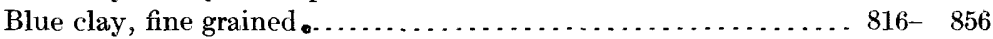

White clay with yellow spots (not water bearing).......... 856-1,001

Analysis of water from Santa Clara well, on King's ranch, Nueces County. ${ }^{a}$

\begin{tabular}{|c|c|c|}
\hline \multicolumn{2}{|c|}{ Parts per million. } & Parts per million. \\
\hline Ammonium (NH) $\ldots \ldots \ldots \ldots \ldots$ & .01 & Total solids at $105^{\circ} \ldots \ldots \ldots \ldots \ldots 680$ \\
\hline Potassium (K) . . . & 11.00 & Total solids ignited, dull redness. 600 \\
\hline Sodium $(\mathrm{Na}) \ldots$ & 130.00 & Loss on ignition.............. 80 \\
\hline Magnesium (Mg). & 16. 00 & Albuminoid ammonia $\left(\mathrm{NH}_{3}\right) \ldots$ \\
\hline Calcium (Ca) ..... & 35.00 & Free ammonia $\left(\mathrm{NH}_{3}\right) \ldots \ldots \ldots \ldots$ \\
\hline $\operatorname{Iron}(\mathrm{Fe}) \ldots . . . .$. & 2.00 & Nitrates...... . . . . . . . . . \\
\hline Chlorine $(\mathrm{Cl}) \ldots \ldots \ldots \ldots \ldots \ldots$ & 140.00 & Nitrites.................... \\
\hline Nitrate radicle $\left(\mathrm{NO}_{3}\right) \ldots \ldots \ldots \ldots .$. & .05 & Oxygen required............... 13 \\
\hline Sulphate radicle $\left(\mathrm{SO}_{4}\right) \ldots \ldots \ldots \ldots$ & 140.00 & Temporary hardness . . . . . . . . . . 260 \\
\hline Bicarbonate radicle $\left(\mathrm{HCO}_{3}\right) \ldots$. & 140.00 & Permanent hardness........... None. \\
\hline Silica $\left(\mathrm{SiO}_{2}\right) \ldots \ldots \ldots \ldots \ldots$ & 24.00 & \\
\hline Organic matter...$\ldots \ldots \ldots \ldots$ & 40.00 & \\
\hline & & \\
\hline
\end{tabular}

a Analysis by H. W. Harper and E. Anderson, school of ehemistry, University of Texas, Austin, April, 1903. 
Analysis of water from Balli well, Secligson ranch, Nueces County.

\begin{tabular}{|c|c|c|c|}
\hline \multicolumn{2}{|c|}{ Parts per million. } & \multicolumn{2}{|c|}{ Parts per million. } \\
\hline Ammonium $\left(\mathrm{NH}_{4}\right) \ldots \ldots \ldots \ldots \ldots$ & 0.08 & Total solids at $105^{\circ} \ldots \ldots \ldots \ldots$ & 1,080 \\
\hline Potassium $(\mathrm{K}) \ldots \ldots \ldots \ldots \ldots$ & 8.30 & Total solids ignited, dull red- & \\
\hline Sodium $(\mathrm{Na}) \ldots . .$. & 270.00 & ness....................... & 930 \\
\hline Magnesium $(\mathrm{Mg}) \ldots . .$. & .90 & Loss on ignition $\ldots \ldots \ldots \ldots$ & 150 \\
\hline Calcium (Ca) ..................... & 69.00 & Albuminoid ammonia $\left(\mathrm{NH}_{3}\right)$.. & .06 \\
\hline Iron $(\mathrm{Fe}) \ldots \ldots \ldots \ldots \ldots \ldots$ & 2.00 & Free ammonia $\left(\mathrm{NH}_{3}\right) \ldots \ldots \ldots$ & .014 \\
\hline Chlorine $(\mathrm{Cl}) \ldots \ldots \ldots \ldots$ & 250.00 & Nitrates. . . . . . . . . . . . & .006 \\
\hline Nitrate radicle $\left(\mathrm{NO}_{3}\right) \ldots \ldots \ldots$ & .01 & Temporary hardness... & 210 \\
\hline Sufphate radicle $\left(\mathrm{SO}_{4}\right) \ldots \ldots \ldots$ & 250.00 & Permanent hardness......... & 63 \\
\hline Bicarbonate radicle $\left(\mathrm{HCO}_{3}\right) \ldots$ & 180.00 & & \\
\hline Silica $\left(\mathrm{SiO}_{2}\right) \ldots \ldots \ldots \ldots \ldots$ & 33.00 & & \\
\hline Organic matter............... & 78.00 & & \\
\hline & & & \\
\hline
\end{tabular}

\section{SAN PATRICIO COUNTY.}

Shallow wells.-In San Patricio County the shallow wells vary in depth from 20 to 130 feet, and they usually furnish a large supply of water.

Artesian wells.-Only a few artesian wells have been bored in this county. A partial list of these is given below:

Artesian wells in San Patricio County.

\begin{tabular}{|c|c|c|c|}
\hline Owner. & Depth. & $\left|\begin{array}{l}\text { Flow per } \\
\text { minute. }\end{array}\right|$ & Diameter. \\
\hline $\begin{array}{l}\text { Coleman \& Fulton... } \\
\text { Mrs. M. M. Murphy. }\end{array}$ & $\begin{array}{r}\text { Feet. } \\
983 \\
365\end{array}$ & $\begin{array}{r}\text { Gallons. } \\
60\end{array}$ & Inches. \\
\hline S. G. Miller............... & & Flows. & \\
\hline
\end{tabular}

\section{REFUGIO COUNTY.}

Shallow wells.- The depth of shallow wells in Refugio County varies from 10 to 60 feet, and they generally furnish a sufficient amount of water for ordinary domestic purposes.

Artesian wells.-Information has been obtained of five artesian wells located on O'Connor's ranch. The depth, flow, and approximate location of these wells are given in the following table:

a Analysis by H. W. Harper and Barney Brooks, school of chemistry, University of Texas, Austin, April, 1903.

IRR $190-07-2$ 
Artesian wells in Refugio County.

\begin{tabular}{|c|c|c|c|}
\hline Owner. & Depth. & $\begin{array}{l}\text { Flow per } \\
\text { minute. }\end{array}$ & $\begin{array}{l}\text { Distance and direction from } \\
\text { Anaqua. }\end{array}$ \\
\hline W' Connor. & $\begin{array}{l}\text { Feet. } \\
946\end{array}$ & $\underset{60}{\text { Gallons. }}$ & 7. 5 miles south, 5 miles west. \\
\hline Do.... & 826 & 175 & 14 miles south, 15 miles west. \\
\hline Do..... & 1,204 & 175 & $\begin{array}{l}11.5 \text { miles south, } 25 \text { miles } \\
\text { west. }\end{array}$ \\
\hline Do. & 972 & 150 & 13 miles south, 5 miles east. \\
\hline Do... & 1,000 & 40 & 19 miles south, 8 miles east. \\
\hline
\end{tabular}

\section{ARANSAs COUNTY.}

Shallow wells.-In Aransas County, which borders the coast, water is obtained at depths varying from 25 to 80 feet.

Artesian wells.-There are at present no artesian wells in this county, and as far as can be ascertained no prospecting has been done.

\section{CALHOUN COUNTY.}

Shallow wells.-The average depth of shallow wells throughout Calhoun County is 30 feet, and in most cases an abundant supply is obtained.

Artesian wells.--There are 21 artesian wells in Calhoun County, mainly on the ranch of T. M. O'Connor. Their approximate location, together with other data, is given in the following table:

Artesian wells in Calhoun County.

\begin{tabular}{|c|c|c|c|}
\hline Owner. & Depth. & $\begin{array}{l}\text { Flow per } \\
\text { minute. }\end{array}$ & $\begin{array}{l}\text { Distance and direction } \\
\text { from Point Lavaca. }\end{array}$ \\
\hline 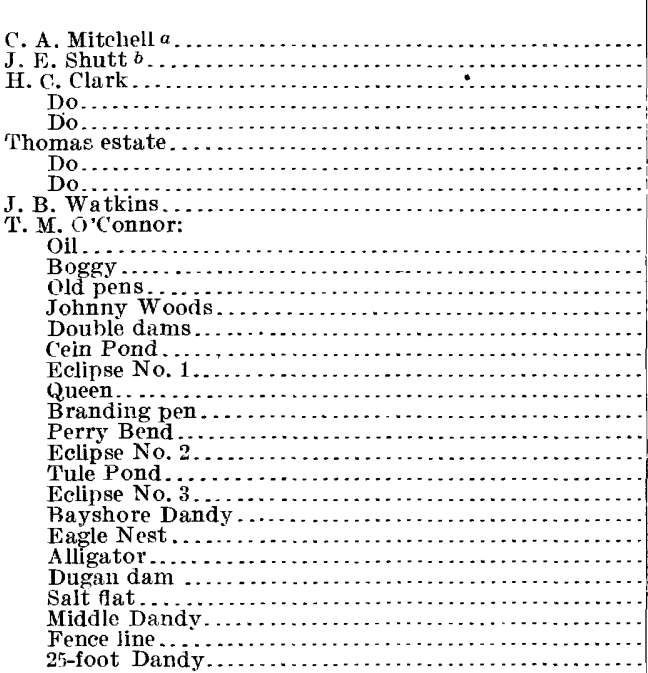 & \begin{tabular}{|r} 
Feet. \\
380 \\
802 \\
496 \\
330 \\
360 \\
441 \\
442 \\
500 \\
366 \\
\\
780 \\
572 \\
570 \\
600 \\
540 \\
490 \\
480 \\
482 \\
460 \\
480 \\
316 \\
315 \\
320 \\
390 \\
460 \\
1,484 \\
380 \\
275 \\
420 \\
480 \\
480
\end{tabular} & 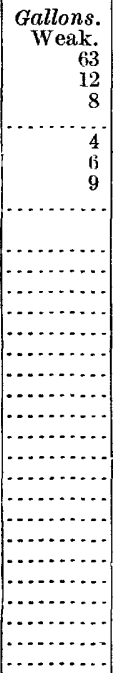 & $\begin{array}{l}4 \text { miles northeast. } \\
8 \text { miles southeast. } \\
8 \text { miles south. } \\
\text { Do. } \\
4 \text { miles south. } \\
5 \text { miles south. } \\
7 \text { miles southwest. } \\
9 \text { miles south. } \\
14 \text { miles southeast. } \\
16 \text { miles southeast. } \\
14 \text { miles southea st. } \\
12 \text { miles southeast. } \\
\text { Do. } \\
14 \text { miles southeast. } \\
\text { Do. } \\
15 \text { miles southeast. } \\
13 \text { miles southeast. } \\
11 \text { miles southeast, } \\
12 \text { miles southeast } \\
10 \text { miles south. } \\
11 \text { miles south. } \\
15 \text { miles south. } \\
\text { Do. } \\
16 \text { miles south. } \\
17 \text { miles south. } \\
18 \text { miles south. } \\
15 \text { miles south. } \\
14 \text { miles south. } \\
\text { Do. }\end{array}$ \\
\hline
\end{tabular}


Surface soil...

Feet.

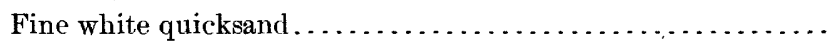

White clay.

$0-\quad 3$

Greenish clay containing shells $2 . . . . . . . . . . . . . . . . .$.

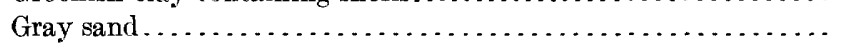

Hard yellowish clay

$3-\quad 21$

$21-\quad 43$

$43-.80$

$80-\quad 83$

Coarse sand containing shells ...................... 160 166

Hard clay containing shells....................... 166- 210

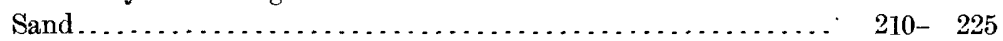

Hard clay containing oyster shells.................... $225-320$

Sand containing oyster shells....................... $320-365$

Blue clay containing a few shells...................... $365-\quad 452$

Coarse gray sand ................................ $452-476$

Conglomerate................................... $476-551$

Gray sand .......................................... $551-567$

Conglomerate with layers of blue clay................... $567-694$

Gray sand, traces of oil............................ $694-\quad 704$

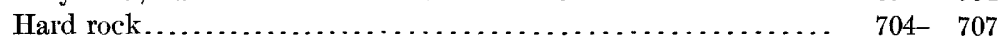

Light sand, traces of oil .......................... $707-710$

Blue clay ..................................... $710-713$

Hard rock with soft layers....................... $713-\quad 725$

Gray sand containing fragments of shells............... $725-767$

"Shell concrete" ................................ $767-887$

Sand, water and oil bearing .......................... $887-912$

Conglomerate.................................. 912- 916

Gray sand .................................. 916- 942

Blue clay containing bowlders and shells............... 942-1,008

Light-colored clay and fine gray sand in alternate layers...... 1,008-1,022

Blue clay ................................ 1,022-1,039

Rock.................................. 1,039-1,042

Blue clay containing bowlders and shells............. 1, 042-1,051

White sand, traces of oil......................... 1,051-1, 052

Blue clay with hard layers....................... 1,052-1, 056

Light-colored clay with hard layers................. 1, 056-1, 087

White sand, water bearing....................... 1,087-1,097

Red and blue clay........................... 1, 097-1, 230

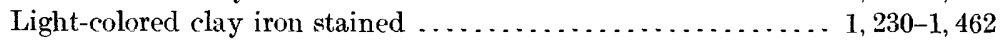

Variegated clay.............................. 1,462 1, 484

\section{VICTORIA COUNTT.}

Shallow wells.- Shallow wells are obtained in Victoria County at depths varying from 30 feet in the southern part to 80 feet in the northern and western parts.

Artesian wells.-Information has been received of 17 artesian wells in this county. The majority of these wells are on the Keeran ranch in the watershed of Garcitas and Aranosa creeks. The following is a list giving their depth, flow, diameter, and approximate location: 
Artesian wells in Victoria County.

\begin{tabular}{|c|c|c|c|c|}
\hline Owner. & Depth. & $\begin{array}{l}\text { Flow per } \\
\text { minute. }\end{array}$ & $\begin{array}{c}\text { Diame- } \\
\text { ter. }\end{array}$ & Location. \\
\hline Rathbone \& Weeder... & $\begin{array}{l}\text { Feet. } \\
1,045\end{array}$ & $\begin{array}{r}\text { Gallons. } \\
\mathbf{8 0}\end{array}$ & Inches. & City of Victoria. \\
\hline J. N. Keeran.......... & 180 & Flows. & ......... & Southeast of Victoria. \\
\hline Do....... & 200 & Flows. & -......... & Do. \\
\hline Do & 148 & Flows. & & Do. \\
\hline Do. & 705 & Flows. & .......... & Do. \\
\hline Do. & 130 & Flows. & -........ & Do. \\
\hline Do. & 77 & Flows. & & Do. \\
\hline Do.. & 50 & Flows. & $\cdots$ & Do. \\
\hline Do. & 222 & Flows. & ..... & Do: \\
\hline Do & 110 & Flows. & $\ldots \ldots$ & Do: \\
\hline Do... & 140 & Flows. & & Do. \\
\hline $\begin{array}{l}\text { Do... } \\
\text { Do. }\end{array}$ & 425 & Flows. & (n...... & Do. \\
\hline A. M. MeFadden. & 716 & $\begin{array}{r}10 \\
10\end{array}$ & 2 & Kemper, \\
\hline Do.. & 592 & 10 & 3 & Kemper, 1.7 miles \\
\hline $\begin{array}{l}\text { Ross Clark..... } \\
\text { Jno. T. Rusk... }\end{array}$ & $\begin{array}{l}152 \\
226\end{array}$ & $\begin{array}{l}50 \\
00\end{array}$ & 2 & $\begin{array}{l}\text { Kemper, } 7 \text { miles nortn. } \\
\text { Inez, } 7 \text { miles rorth. }\end{array}$ \\
\hline
\end{tabular}

\section{JACKSON COUNTY.}

Shallow wells.-Water is obtained in the eastern part of Jackson County at depths varying from 25 to 40 feet; in the southern and western parts from 40 to 60 feet; and in the northern part from 25 to 45 feet.

Artesian wells.-Artesian water has been found in this county south of the New York, Texas, and Mexican Railway, and it is believed by local observers that artesian water can be obtained almost anywhere in the northern part of the county. The following table gives a list of the wells, with their depth, flow, and approximate location.

Artesian wells in Jackson County.

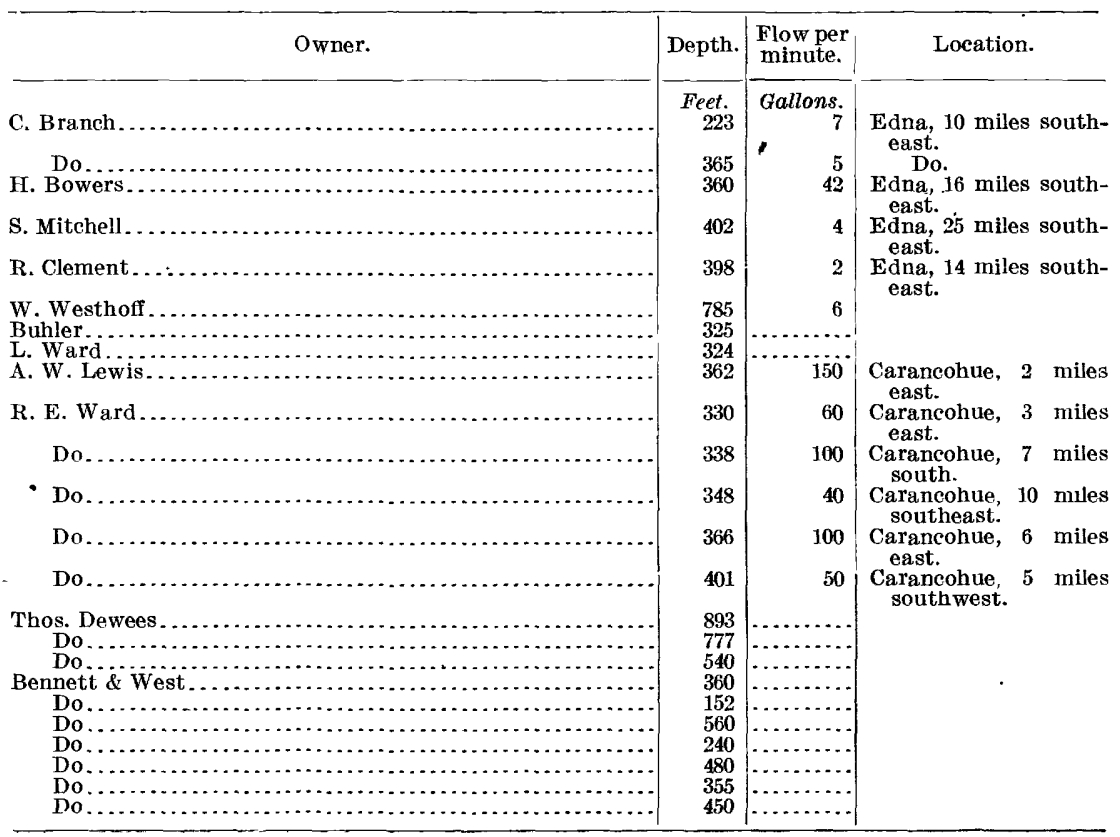


A well owned by S. H. Beasley, drilled in 1903 close to the west bank of Navidad River, about 1 mile north of the crossing of the New York, Texas and Mexican Railway, has the following record:

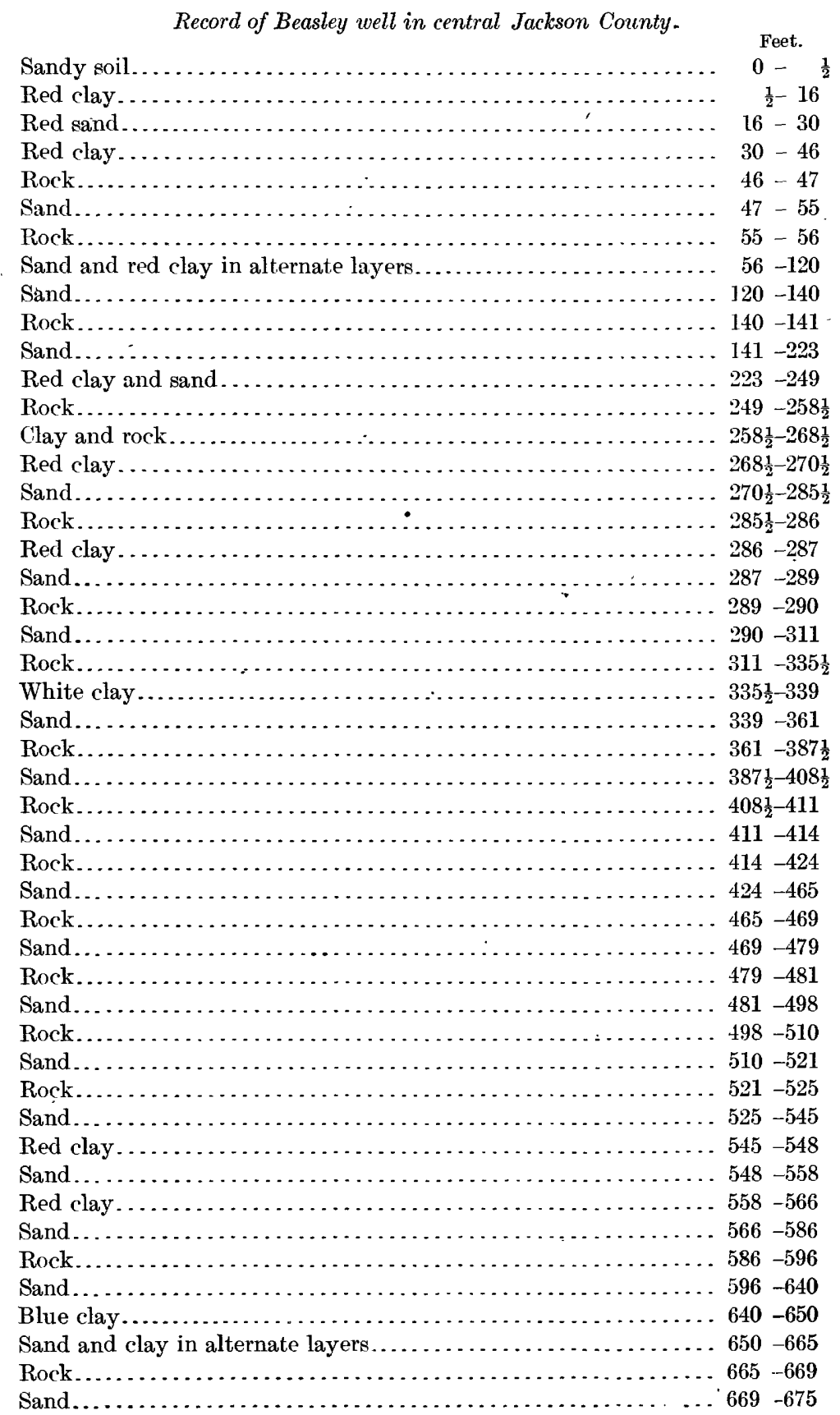




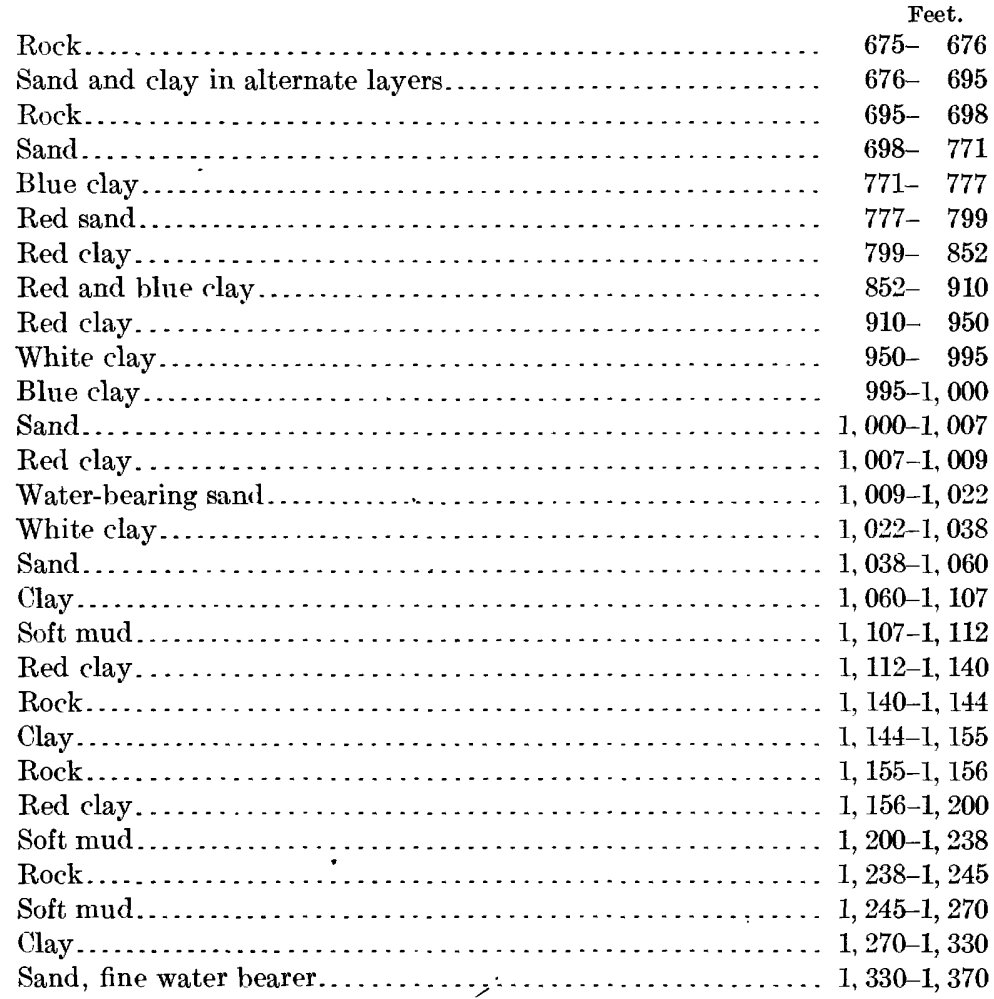

An artesian well owned by Russell Ward, 25 miles from Edna, in the southeast corner of Jackson County, has the following record:

Record of Ward artesian well in southeastern Jackson County.

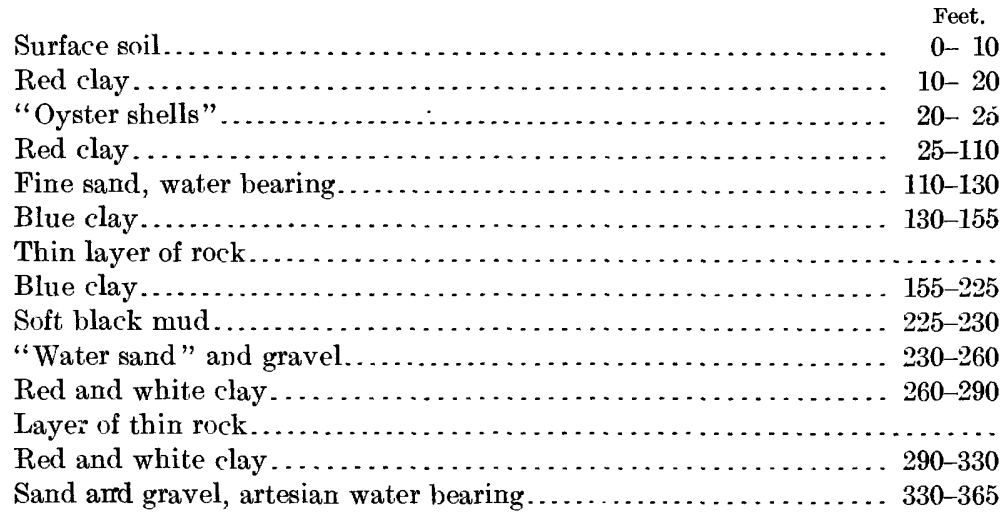




\section{MATAGORDA COUNTY.}

Shallow wells.-In Matagorda County shallow wells are from 15 to 30 feet deep.

Artesian wells.-Artesian water has been secured at many places, especially in the southern part of the county. Data respecting these wells are given in the following table:

Artesian wells in Matagorda County.

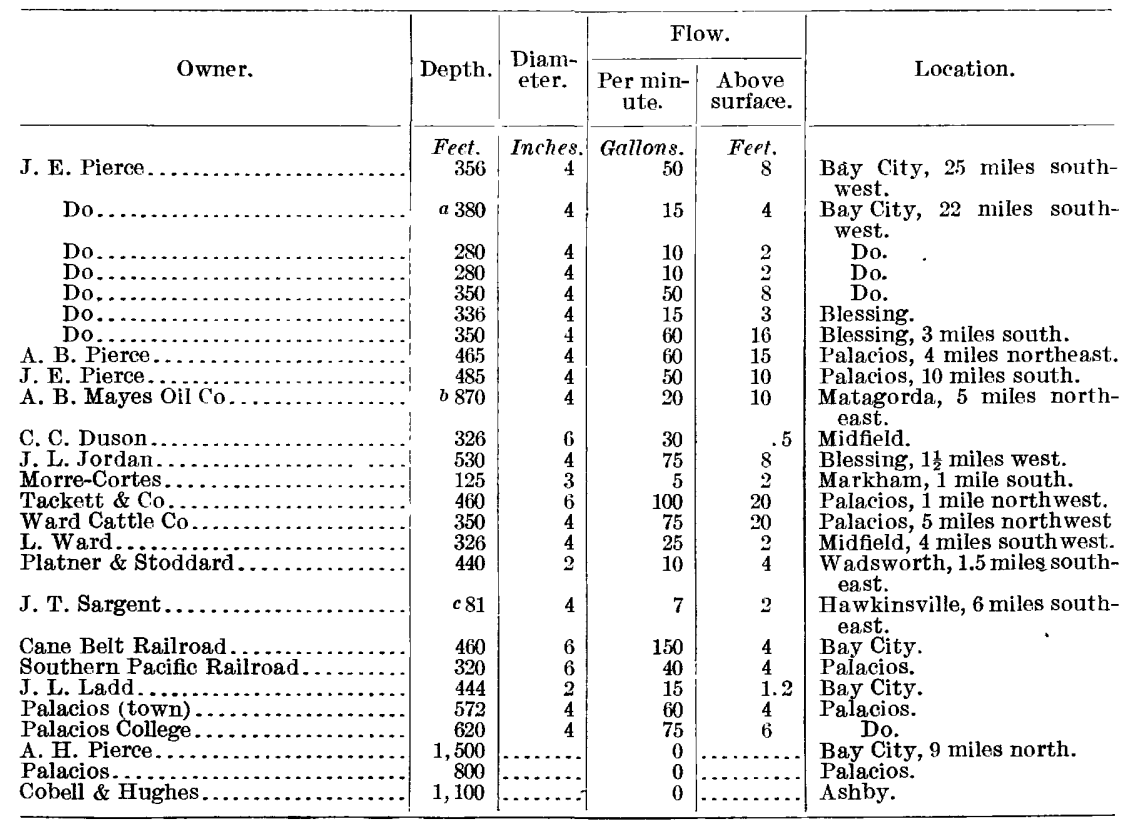

$a$ Sulphur water at 280 feet; bored 100 feet farther and good water obtained.

$b$ Bored for oil; flows warm sulphur water, which is slightly saline.

c John T. Sargent has about 12 deep wells on his ranch. They average about 80 feet in depth and the water rises within 2 feet of the surface.

\section{WHARTON COUNTY.}

Shallow wells.--In Wharton County west of Colorado River water can be obtained from wells varying in depth from 15 to 30 feet. In the vicinity of El Campo many rice farms are supplied with water from shallow wells. Here the water-bearing sand lies about 15 feet below the surface. A pit 4 to 6 feet in diameter is dug to the waterbearing sand and in the bottom of this excavation three or four wells are drilled. These wells are all cased, and to the top of the casing centrifugal pumps, operated by engines on the surface, are attached. In this way a large supply of water is brought to the surface and used extensively in the irrigation of rice. The most successful shallowwell irrigation plants in Texas are in the vicinity of El Campo.

Artesian wells. - On account of the shallow depth at which ground water can be secured, few attempts have been made to obtain artesian water. The only artesian well in the county of which a record has been kept is known as the Borden well and was drilled in 1892. It 
is located near Pierce and has a depth of 1,509 feet. A complete record of the beds penetrated is given below:

Record of A. P. Borden well, Pierce station, Wharton County.

Clay and sand

Feet.

Red sand . . . . . . . . . . . . . . . .

$0-\quad 30$

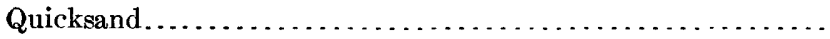

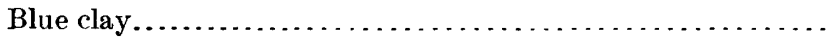

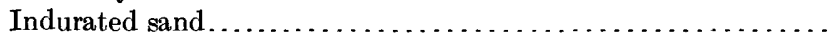

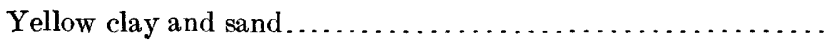

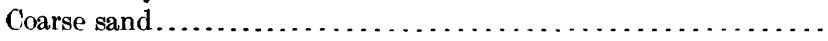

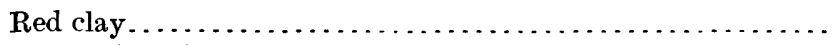

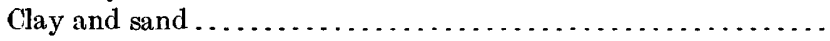

$30-\quad 35$

$35-\quad 43$

$43-\quad 53$

$53-70$

$70-\quad 100$

$100-106$

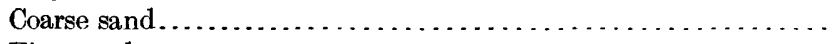

Fine sand

$106-127$

$127-\quad 191$

191- 214

Red clay.

214- 250

Fine sand $\ldots \ldots \ldots \ldots \ldots \ldots \ldots \ldots \ldots \ldots \ldots \ldots \ldots \ldots \ldots \ldots \ldots$

$250-254$

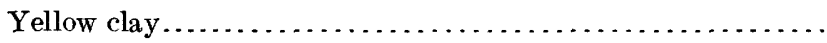

$254-\quad 270$

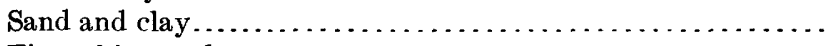

$270-\quad 280$

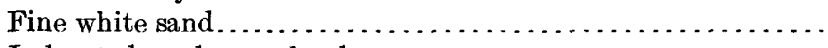

$280-300$

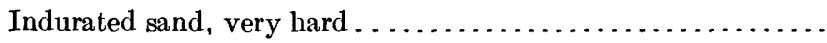

$300-373$

$373-\quad 383$

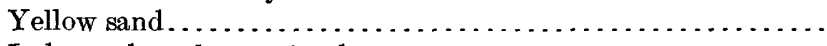

383- 385

Indurated sand, very hard $\ldots \ldots \ldots \ldots \ldots \ldots \ldots \ldots \ldots \ldots \ldots . .385-\quad 410$

Yellow sand mixed with thin layers of clay............... $410-\quad 460$

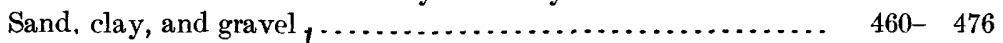

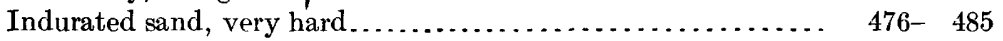

Indurated sand, soft and hard layers alternating........... $485-529$

Indurated sand, very hard . . . . . . . . . . . . . . . . . . . . $529 . . \quad 549$

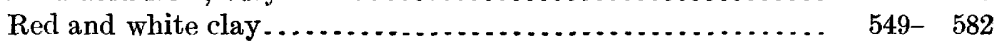

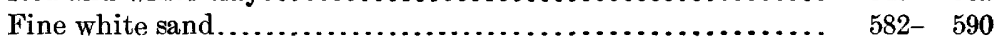

Indurated sand with soft layers ...................... $590-612$

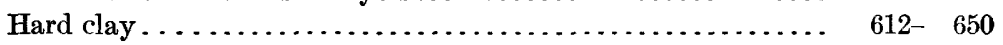

Very hard sandstone.............................. $650-687$

Limestone, very hard ............................ $687-693$

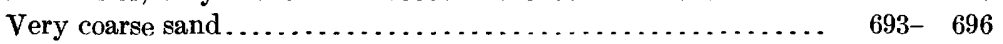

Limestone, very hard ........................... $696-700$

White clay ................................... $700-730$

Very hard white clay ............................. $730-745$

Soft mottled clay .................................. $745-786$

Red mottled clay . . . . . . . . . . . . . . . . . . . . 818

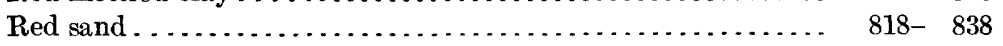

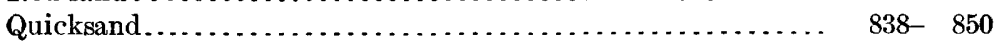

Red clay ..................................... $850-890$

Gray sand .................................... $890-920$

Very hard white clay ............................ $920-938$

Gray sand .................................... 938- 970

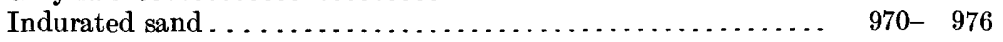

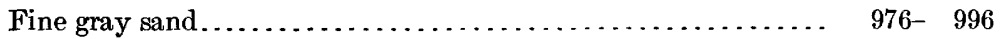

Hard clay . . . . . . . . . . . . . . . .

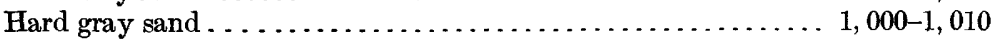

White clay ..................................... 1,010 $-1,015$

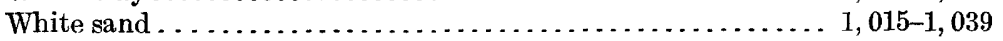

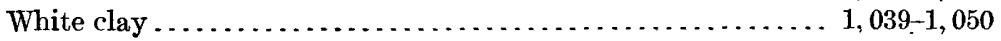

Very hard white clay $\ldots \ldots \ldots \ldots \ldots \ldots \ldots \ldots \ldots \ldots \ldots \ldots, 1,050-1,053$ 
Feet.

Rock....................................... 1,053-1,065

Very hard white clay ............................. 1,065-1,076

Sandstone and hard blue clay . . .................... 1,076-1, 128

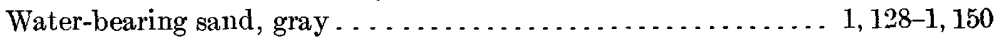

White clay . . . . . . . . . . . . . . . . . . . . . .

Red clay.................................... 1, 205-1,359

Fine red sand ................................. 1,359-1,366

Red clay ...................................... 1,366-1,450

White clay .................................. 1,450-1,470

White clay with sand............................ 1,470-1,509

In the southern part of Wharton County, near the Matagorda County line, there are two small artesian wells owned by the Texas Land and Cattle Company. These are 2-inch wells, 315 and 513 feet deep, respectively, the former having a flow of 1 gallon and the latter 8 gallons a minute.

\section{BRAZORIA COUNTY.}

Shallow wells.-Wateris obtained from shallow wells throughout Brazoria County at depths which vary from 15 to 30 feet.

Artesian wells.-Flowing wells are widely distributed throughout the county, on both the east and west sides of Brazos River. They vary considerably in depth, some being over 1,000 feet, and in the amount of flow they range from a few gallons to over 700 gallons a minute. The water is generally of good quality, but from a few wells saline flows have been reported.

Artesian wells in Brazoria County.

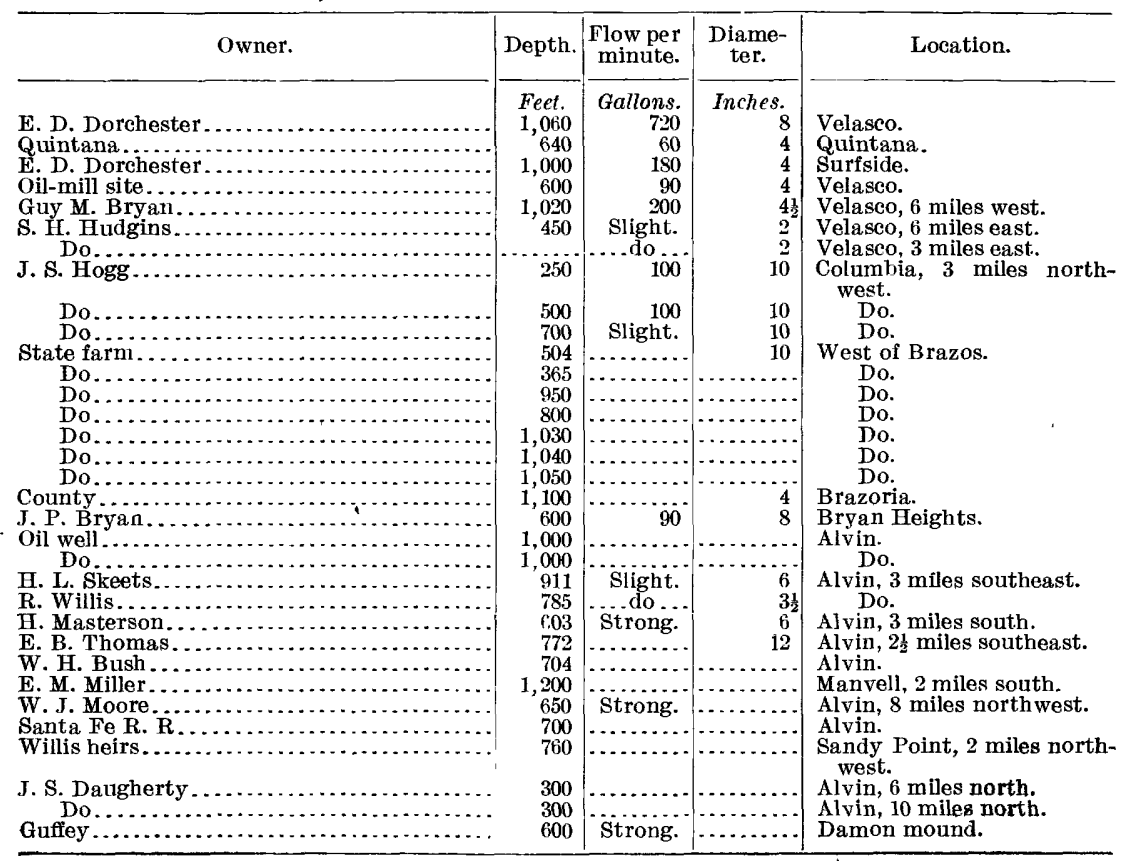




\section{Record of Arnold well No. 3, Columbia, Brazoria County.}

Surface soil, clay, and sand.

Feet.

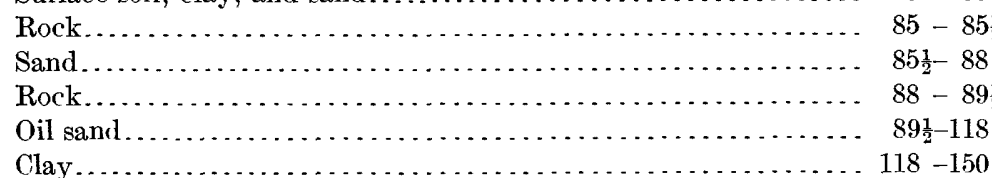

$0-85$

$85-85 \frac{1}{2}$

$85 \frac{1}{2}-88$

$88-89 \frac{1}{2}$

$89 \frac{1}{2}-118$

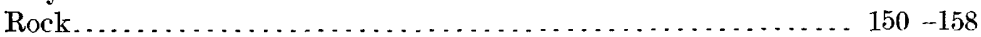

Blue clay ..................................... $158-192$

Soft rock. . . . . . . . . . . . . . . . . . . . . . . . . . . . . $192-196$

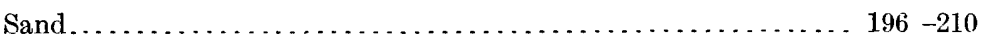

Soft rock....................................... $210-212$

Blue clay .......................................... $212-218$

Soft rock......................................... . $218-219$

Blue clay......................................... $219-260$

Soft lime rock.................................. $260-261$

Blue clay, very tough............................. $261-275$

Rock (hard layer at 294 feet contains some gas) . . . . . . . . . . $275-299$

Hard rock . . . . . . . . . . . . . . . . . . . . . . . . . . . . . . . . . $299-315$

Crystallized sand .................................. $315-328$

Blue clay .............. . . . . . . . . . . . . . . . . . . . . . . $328-333$

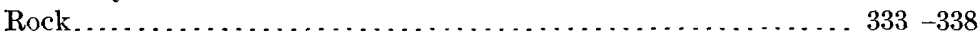

Sand ............................................ $338-343$

Blue clay .......................................... $343-346$

Compact sand ............................................ $346-354$

Clay............................................ $354-368$

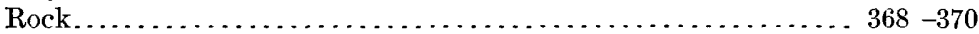

Clay ............................................. $370-395$

Soft rock..................................... $395-397$

Blue clay ......................................... $397-405$

Rock.......................................... $405-406$

Blue clay ..................................... $406-428$

Crystallized sand ................................. $428-462$

Blue clay, very hard and oil saturated................. $462-484$

Soft reck........................................ $484-486$

Blue clay ....................................... $486-510$

Sand, very compact........................... $510-532$

Rock, full of pyrites and shell....................... . 532 -534

Sand, very compact................................... 534 -574

Hard rock, conglomerate, pyrites, and lime; rock sulphur and

shell....................................... 574 -582

Hard blue clay ................................ $582-620$

Rock, pyrites, sulphur, lime, volcanic crystals, and oil saturations ....................................... $620-628$

Blue clay ........................................... $628-632$

Rock with sand ............................... . $632-651$

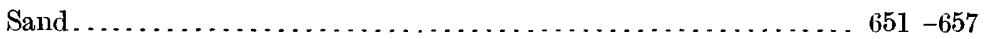

Rock ............................................ $657-675$

Hard rock. . . . . . . . . . . . . . . . . . . . . . . . . . . $675-676$

Sand ........................................ $676-678$

Very hard rock................................ $678-680$

Sand, color of oil.............................. $680-681$

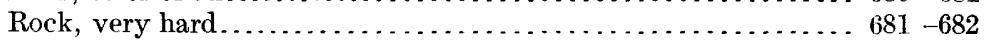

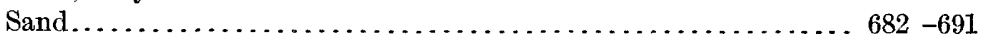




\begin{tabular}{|c|c|}
\hline & Feet. \\
\hline Blue clay........ & $691-719$ \\
\hline 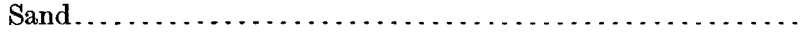 & $719-$ \\
\hline Blue clay.............. & $723-$ \\
\hline Oil sand........ & $729-$ \\
\hline Blue clay... & $734-$ \\
\hline 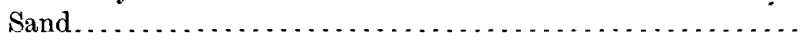 & $800-835$ \\
\hline Shell with some little showing of oil. & $835-857$ \\
\hline Blue clay, very thin strata full of shell $\ldots \ldots \ldots \ldots \ldots \ldots \ldots$ & $857-858$ \\
\hline 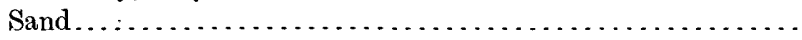 & $858-$ \\
\hline Blue clay $\ldots \ldots \ldots \ldots \ldots \ldots \ldots \ldots \ldots \ldots \ldots \ldots$ & $870-$ \\
\hline 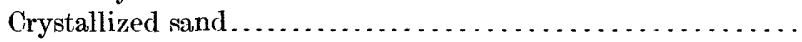 & $906-926$ \\
\hline Rock & $926-936$ \\
\hline Blue clay $\ldots . . . \ldots \ldots \ldots \ldots$. & $936-943$ \\
\hline Sand ................... & $943-970$ \\
\hline Soft sandstone ............ & $970-971$ \\
\hline Hard sandstone $\ldots \ldots \ldots \ldots \ldots \ldots \ldots$ & $971-973$ \\
\hline 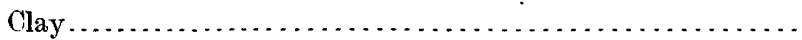 & $973-989$ \\
\hline 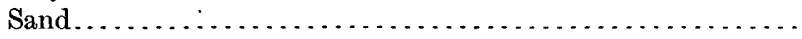 & $989-1,002$ \\
\hline 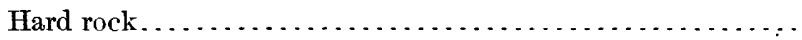 & $1,002-1,004$ \\
\hline Sand, fairly firm, contains fossil wood $\ldots \ldots \ldots \ldots \ldots \ldots$ & $1,004-1,012$ \\
\hline 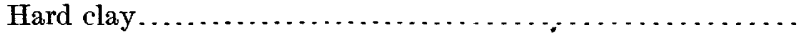 & $1,012-1,050$ \\
\hline Sand with a little gas............... & $1,050-1,110$ \\
\hline Blue clay ................. & $1,110-1,115$ \\
\hline Sand $\ldots \ldots \ldots \ldots \ldots \ldots \ldots$ & $1,115-1,136$ \\
\hline Soft rock, or compact sand.......... & $1,136-1,214$ \\
\hline
\end{tabular}

Record of well on lot 234, Hoskins Mound (midway between Velasco and Alvin), Brazoria County.

Black surface clay

Pale blue clay ............................... $4-12$

Red clay.................................... $12-25$

Yellow loamy sand, rather fine....................... $25-45$

Blue gumbo.................................. $45-85$

Blu quicksand................................ $85-130$

Blue clay filled with small white shells................ $130-152$

Blue quicksand.................................... $152-172$

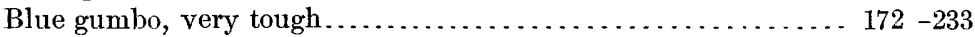

Blue sand, fine grained, with black specks; first indication of oil. $233-239$

Sand with come clay ............................. $239-378$

Blue sand, coarse, with black specks; some oil near bottom.... $378-423$

Blue clay with some small shells..................... $423-465$

Coarse blue sand with black specks...................... $465-500$

Blue sand with some brown layers, contains iron pyrite and some small shells................................ $500-530$

Soft blue clay with small shells....................... $530-535$

Blue clay with larger shells.......................... . . 535 -555

Blue clay with few shells........................... $555 \quad-580$

Blue gumbo, very tough; shells.................... $580-595$

Tough blue clay with few shells....................... $595-628$

Blue sand with gravel and some shells................. $628-632 \frac{1}{2}$

Blue sand with coarse black particles................... $632 \frac{1}{2}-642 \frac{1}{2}$

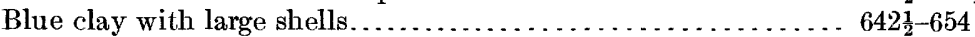

Blue clay with shell fragments......................... $654-674$ 
Feet.

Blue sand, gravel with black particles; considerable gas . . . . . . 674 6784

Blue sand with many black particles; good show of oil from 688 to 692 feet . . . . . . . . . . . . . . . . . . . . . . . . . . . . . $684-692$

Bluish sand, coarse; shows oil saturation ................ $692-711$

Tough blue clay containing shells. . . . . . . . . . . . . . . $711-720$

Tough blue gumbo containing bowlders. .............. $720-722$

Blue clay and sand; show of oil................... $722-728$

Blue clay with thin layers of sandstone............... $728-735$

Tough blue gumbo.............................. $735-755$

Blue gumbo with thin layers of sandstone and limestone...... $755-778$

Blue sand with iron pyrites; some show of oil at 778 feet. . . . $778-783$

Tough blue gumbo with thin layers of sandstone and limestone;

considerable iron pyrites........................ $783-786$

Blue gumbo with shells. ............................ $786-793$

Sand with iron pyrites; "oil show" ..................... $793-794$

Tough blue gumbo.................................. $794-799$

Very hard blue clay with rock 2 to 6 feet thick, mostly limestone. $799-825$

\section{FORT BEND COUNTY.}

Shallow wells.-Water in sufficient quantity for ordinary domestic purposes is obtained throughout Fort Bend County at depths of 15 to 40 feet.

Deep wells.-A few deep pump wells have been sunk. Two on the Cunningham farm near Sugar Land are 1,000 feet deep. The town of Richmond derives its water supply from a pump well 400 feet deep. The following is a list of some of the deeper wells in this region.

Deep wells in Fort Bend County.

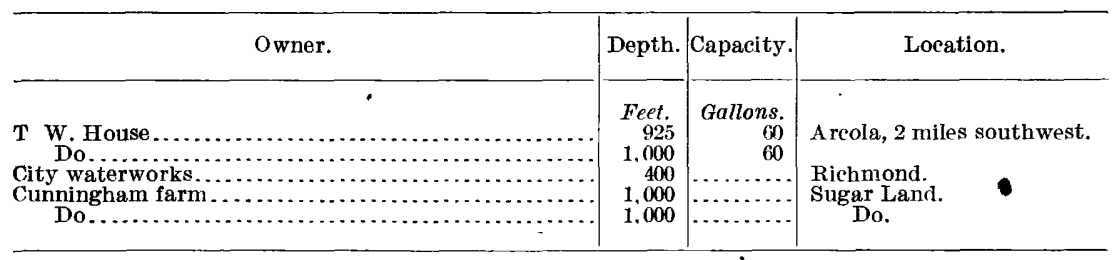

\section{HARRIS COUNTY.}

Shallow wells.-Good shallow wells have been bored in Harris County, at Clodine, Erin, Katy, and Deepwater, and it is believed that wells of this character may be obtained throughout the county. In the vicinity of Clodine, on the rice farms of the Meadow Brook Company, the wells are generally 150 feet deep and 10 inches in diameter, the water rising within 15 to 20 feet of the surface. Wells on the J. H. O'Donnell farm, at Erin, are less than 100 feet deep and penetrate 46 feet of water-bearing sand. At Katy the two wells of J. E. Cabaniss are 93 and 94 feet deep.

Artesian wells.-There are about 140 artesian wells in Harris County, 80 of these being at Houston, where the artesian water resources have been better developed than in any other part of the 
State. The city water supply of Houston is derived from 60 artesian wells which have been drilled in an area of 14 acres lying on either side of Buffalo Bayou. The general distribution of these and other artesian wells in Harris County is shown in Pl. II (p. 2), and the following tables contain all available information concerning them:

Artesian wells in Harris County.

\begin{tabular}{|c|c|c|c|c|}
\hline Owner. & Depth. & $\begin{array}{l}\text { Flow per } \\
\text { minute. }\end{array}$ & $\begin{array}{l}\text { Diame- } \\
\text { ter. }\end{array}$ & Location. \\
\hline & Feet. & Gallons. & Inches. & \\
\hline A. L. Smith $\ldots \ldots \ldots \ldots \ldots \ldots \ldots \ldots \ldots \ldots \ldots \ldots \ldots$ & 570 & Flows. & $\ldots \ldots . . .$. & Webster, 1 mile south. \\
\hline 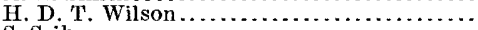 & 520 & Flows. & ........... & Webster. \\
\hline S. Seibara . . . . . . . . . . . . . . . . . . & 670 & Flows. & $\ldots \ldots \ldots$ & Webster, $\frac{1}{4}$ mile east. \\
\hline S. T. Nishimura . . . . . . . . . . . . . . . & 475 & Flows. & $\ldots . . . . .$. & Webster, 3 miles northeast. \\
\hline 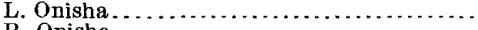 & 615 & Flows. & $\ldots \ldots . . .$. & Webster, 1 mile north. \\
\hline 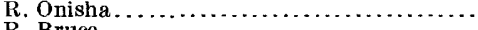 & 470 & Flows. & ........... & Do. \\
\hline & 500 & Flows. & - $\ldots \ldots \ldots$ & Webster, 3 miles east. \\
\hline $\begin{array}{l}\text { J. A. Caplen } \ldots \\
\text { Railroad Co } \ldots \ldots \ldots\end{array}$ & $\begin{array}{l}450 \\
650\end{array}$ & $\begin{array}{l}\text { Flows. } \\
\text { Flows. }\end{array}$ & $\cdots+$ & $\begin{array}{l}\text { Webster, } \frac{1}{4} \text { mile northeast. } \\
\text { Genoa. }\end{array}$ \\
\hline City & 600 & Flows. & & Do. \\
\hline$\ldots \ldots \ldots \ldots \ldots$ & 90 & Flows. & .... & Genoa, 2 miles north. \\
\hline 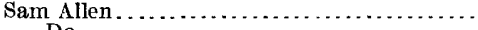 & 250 & Flows. & & Genoa, 2 miles south. \\
\hline 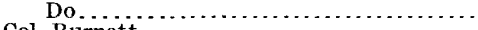 & 250 & Flows. & $\ldots .$. & Genoa, 4 miles south. \\
\hline 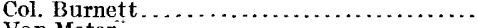 & 700 & Flows. & 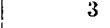 & Genoa. \\
\hline 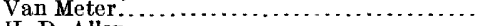 & 300 & Flows. & $\ldots \ldots . . .$. & Genoa, 1 mile south. \\
\hline 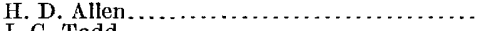 & 660 & Flows. & $\ldots .$. & Seabrook, 3 miles northeast. \\
\hline J. G. Todd . . . . . . . . . . . . . . . . . & 640 & Flows. & 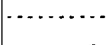 & $\begin{array}{l}\text { Seabrook, } 1 \frac{1}{4} \text { miles north- } \\
\text { east. }\end{array}$ \\
\hline Alf Palm. & 670 & 70 & 3 & Seabrook, $\frac{3}{4}$ mile northeast \\
\hline 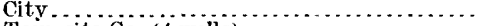 & 660 & Flows. & & Seabrook. \\
\hline Townsite Co. (4 wells) $\ldots . \ldots \ldots \ldots \ldots \ldots$. . . . . & $440-500$ & Flows. & 3 & La Porte. \\
\hline 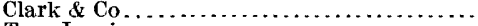 & 440 & 350 & 6 & Do. \\
\hline Tom Jennings . . . . . . . . & 380 & 170 & 4 & I.a Porte, Spillway Island. \\
\hline Gajveston, Houston and Northern R. R... & 450 & Flows. & ............. & Strange. \\
\hline 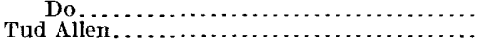 & 450 & $\begin{array}{l}\text { Flows. } \\
\text { Flows. }\end{array}$ & $\ldots$ & $\begin{array}{l}\text { Do. } \\
\text { Morgan Point. }\end{array}$ \\
\hline N. A. Baker & 440 & Flows. & $\ldots$ & Do. \\
\hline Q. A. Wooster $\ldots \ldots \ldots \ldots \ldots \ldots \ldots \ldots \ldots \ldots \ldots$ & 217 & Flows. & $\cdots$ & Wooster, 1 mile west. \\
\hline W. E. Jones...... & 330 & Flows. & & Deepwater. \\
\hline 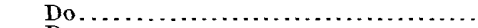 & 310 & Flows. & $\ldots$ & Deepwater, 1 mile north. \\
\hline$\ldots \ldots \ldots . . . . . .$. & 340 & Flows. & $\ldots$ & Deepwater, $1 \frac{3}{4}$ miles north. \\
\hline Do. & 340 & Flows. & ... & Deepwater, 2 miles north. \\
\hline Do...... & 330 & Flows. & & $\begin{array}{l}\text { Deepwater, } 1 \text { mile south- } \\
\text { east. }\end{array}$ \\
\hline Col. Hill. & 230 & Flows. & $\ldots \ldots \ldots=$ & $\begin{array}{l}\text { Deepwater, } 1 \text { mile north- } \\
\text { east. }\end{array}$ \\
\hline W right. & 300 & Flows. & & Deepwater, 2 miles north- \\
\hline L. Zlemke. & 300 & Flows. & & Do. \\
\hline P. H. West.. & 344 & Flows. & & Deerspark. \\
\hline 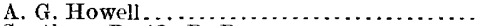 & 324 & Flows. & & Do. \\
\hline Southern Pacific R. R............. & 330 & Flows. & $\cdots$ & Do. \\
\hline Public well $\ldots . . . . \ldots \ldots \ldots . . . . . . . . .$. & 290 & Flows. & ... & Pasadena. \\
\hline 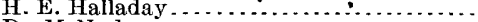 & 310 & Flows. & $\ldots$ & Do. \\
\hline Dr. Mc Nyder . . . . . . . . . . . . . . . . . . . & 180 & Flows. & $\ldots$ & Do. \\
\hline I. L. Pitts. & 210 & Flows. & ... & Do. \\
\hline 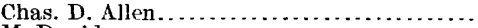 & 659 & 100 & $\ldots$ & Harrisburg, 1 mile east. \\
\hline M. Davidson . . . . . . . . . . . . . . . . & 500 & Flows. & $\ldots \ldots \ldots$ & Alameda, 1.5 miles north. \\
\hline G. Dogg . . . . . . . . . . . . . & 450 & Flows. & $\ldots$ & Alameda, 3.5 miles east. \\
\hline F. E. Markley............ & 65 & Flows. & $\ldots$ & Aldine, $\frac{3}{4}$ mile northeast. \\
\hline Kellogg. . . . . . . & 400 & Flows. & $\ldots$ & Aldine, 4 miles southeast. \\
\hline C. W. Hahl.. & 240 & F]ows. & $\ldots$ & Aldine, 5 miles northwest. \\
\hline Do $\ldots \ldots \ldots \ldots \ldots$ & 280 & Flows. & ... & Aldine, 4 miles west. \\
\hline 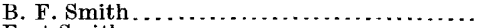 & 88 & Flows. & $\ldots \ldots \ldots$ & Barker, 2 miles south \\
\hline Fort Smith............ & 180 & Flows. & & Addicks, 3 miles southwest. \\
\hline H. F. V. Blender........ & 500 & Flows. & & Humble. \\
\hline Magnolia Brewery Co... & 150 & 35 & & Houston. \\
\hline Do.................... & 300 & 209 & ... & Do. \\
\hline Do. & 200 & 104 & & Do. \\
\hline Do. & 500 & 249 & & Do. \\
\hline 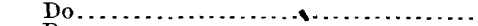 & 500 & 250 & & Do. \\
\hline Do.............. & 500 & 490 & & Do. \\
\hline Do $\ldots$ & 800 & Flows. & & Do. \\
\hline American Brewery Co. & 180 & 40 & & Do. \\
\hline Do................ & 242 & 125 & & Do. \\
\hline Do....... & 339 & 75 & $\ldots$ & Do. \\
\hline 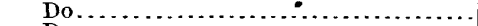 & 800 & 95 & & Do. \\
\hline 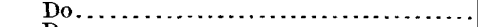 & 570 & 45 & $\ldots$ & Do. \\
\hline Do...... & 830 & 175 & & Do. \\
\hline
\end{tabular}


Artesian wells of waterworks at Houston, Harris County.

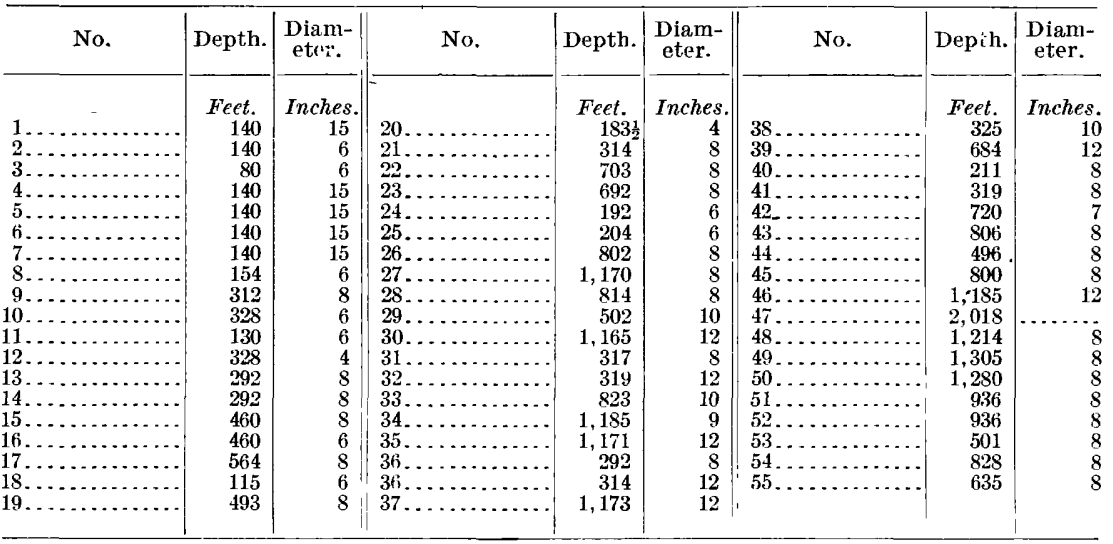

Record of well No. 28, Houston, IIarris County.

Surface soil

Clay

Sand and rock

Clay 44- 74

Sand $74-89$

and gravel

89- 93

White clay

93-137

Sand. 137-210

Clay and gravel 210-290

White sand and gravel, water hearing; hard to finish . . . . . . . . . . 290-316

Clay and gravel................................ $316-356$

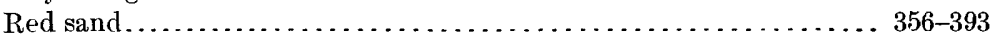

Clay and gravel. ............................... $393-456$

White clay and gravel............................ $456-496$

Sand, clay, and gravel............................... $496-514$

Sand.......................................... . . $514-526$

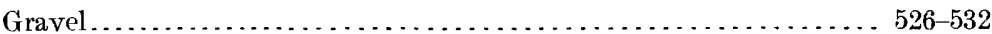

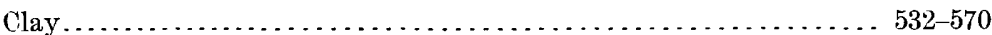

Limestone. . . . . . . . . . . . . . . . . . . . . . . . . $570-571$

Sand and gravel. ................................ . $571-585$

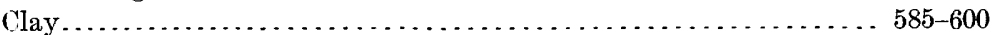

Hard rock. . . . . . . . . . . . . . . . . . . . . . . . . . . 600-602

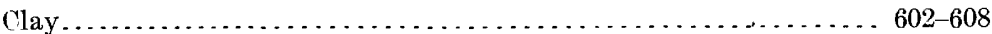

Sand ......................................... 608618

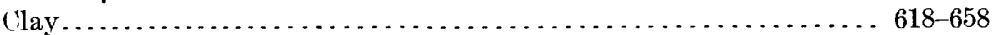

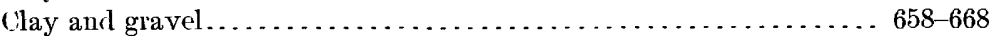

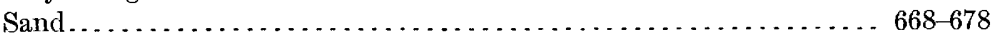

Clay and sand . . . . . . . . . . . . . . . . . . . . . . . . . . 678-687

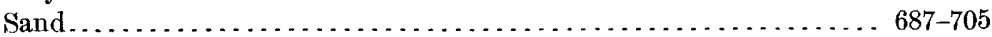

Clay and gravel. . . . . . . . . . . . . . . . . . . . . . . $705-745$

Sand . . . . . . . . . . . . . . . . . . . . . . . . . . . $745-756$

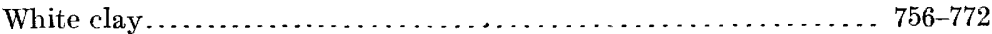

Water-bearing sand............................... $772-814$ 
Record of deep well at Houston, Harris County.

Clay and sand

Feet.
$0-154$
$154-161$
$161-163$
$163-210$
$210-280$
$280-312$
$312-345$
$345-345 \frac{1}{2}$
$345 \frac{1}{2}-350$
$350-415$
$415-420$
$420-465$
$465-502$
$502-540$
$540-570$
$570-605$
$605-643$
$643-670$
$670-702$
$702-745$
$745-769$
$769-779$
$779-805$
$805-810$
$810-835$
$835-895$
$895-940$
$940-1,134$
$134-1,137$
$137-1,179$
$1,179-1,236$
$1,236-1,314$
$, 314-1,315$
$1,315-1,334$
$, 334-1,368$
$1,368-1,430$
$430-1,470$
$470-1,600$
$1,600-1,605$
$605-1,895$
$1,895-1,907$
$, 907-2,025$

Sand, water bearing . . . . . . . . . . . . . . . . .

Clay

Sand

Clay

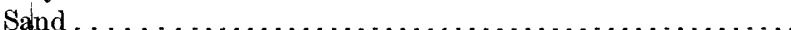

Glay

Rock.

Sand.

Clay

Sand.

Clay.

Sand.

Clay

Sand

Clay.

Sand and gravel.

Clay.

Sand and gravel.

Clay .

Sand

Clay.

Sand

Clay.

Sand

Clay.

Sand

Clay

Rock

Sand

Clay

Sand

Rock

Clay.

Sand.

Clay

Sand and gravel

Clay and rock.

Rock with gas.

Clay.

Sand

$1,907-2,025$

\section{GALVESTON COUNTY.}

Shallow wells.-In Galveston County the average depth of shallow wells is 25 feet.

Artesian wells.-The log of the-deep well at Galveston, bored about 1892 , clearly indicates that artesian water could be found in the coast region at much shallower depths than that reached by this boring. The record down to the water-bearing sand is given below. There are at present about 90 artesian wells in Galveston County. Their 
approximate location is shown in $\mathrm{Pl}$. II. The most important group of these wells is located 18 miles from Galveston, at Alta Loma, where 30 wells have been drilled on both sides of the Santa Fe Railway track. The original contract for these wells specified that 33 wells should be bored and a supply of 5,000,000 gallons every twenty-four hours guaranteed. When 30 wells had been sunk, the yield was 9,000,000 gallons every twenty-four hours, 4,000,000 gallons more than the contract amount. The wells are located in a line that trends nearly north and south, and there are about an equal number on each side of the railroad track. They are provided with pipes that connect with mains to a standpipe on the north side of the track. The wells are about 868 feet deep, and all receive their water from a bed of water-bearing sand 128 feet thick, which rests upon a layer of hard clay. This water horizon was encountered in all wells at a depth of 740 to 750 feet, but some were not bored through the water-bearing sand. The following table shows the depths of wells on the south side of the railroad:

Partial list of wells at Alta Loma, Galveston County.

\begin{tabular}{|c|c|c|c|c|c|c|c|c|}
\hline No. & Deptl. & $\begin{array}{c}\text { Diame- } \\
\text { ter. }\end{array}$ & No. & Depth. & $\begin{array}{c}\text { Diame- } \\
\text { ter. }\end{array}$ & No. & Depth. & $\begin{array}{c}\text { Diame- } \\
\text { ter. }\end{array}$ \\
\hline $\begin{array}{r}2 \\
4 \ldots \ldots \\
6 \ldots \ldots \\
8 \ldots \ldots \\
10 \ldots \ldots \\
\end{array}$ & $\begin{array}{r}\text { Feet. } \\
792 \\
868 \\
793 \\
809 \\
792\end{array}$ & $\begin{array}{r}\text { Inches. } \\
7 \\
7 \\
7 \\
5 \\
5\end{array}$ & 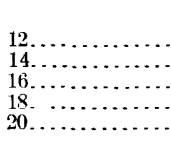 & $\begin{array}{r}\text { Feet. } \\
788 \\
800 \\
838 \\
790 \\
775\end{array}$ & $\begin{array}{r}\text { Inches. } \\
5 \\
5 \\
5 \\
5 \\
5\end{array}$ & $\begin{array}{l}22 \ldots \ldots \ldots \\
24 \ldots \ldots \ldots \ldots \ldots\end{array}$ & $\begin{array}{r}\text { Feet. } \\
726 \\
733 \\
745\end{array}$ & $\begin{array}{r}\text { Inches. } \\
5 \\
5 \\
9\end{array}$ \\
\hline
\end{tabular}

Record of well at Altu Loma, Galveston County. ${ }^{\iota}$

Feet.

Surface soil.................................... 4

Clay.......................................... 42

Quicksand..................................... 12

Very red clay .................................. 18- 25

Red quicksand ................................... 25-35

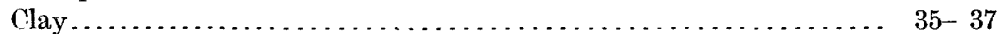

Quicksand ..................................... $37-40$

Red and white clay ............................... 40-100

Sand, water bearing; no flow .......................... 100-123

White clay............................................ 123-150

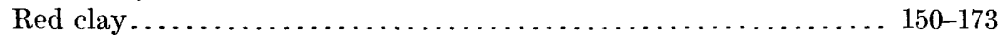

Very hard red clay.................................. 173-190

Hard and soft clay ................................. 190-208

Soft red clay . . . . . . . . . . . . . . . . . . . . . . . . . . . . . . . 208-218

Hard clay ......... . . . . . . . . . . . . . . . . . . . . . . . . 218-230

Quicksand..................................... 230-385

Hard and soft white clay ................................. 385-435

Soft white clay.................................... 435-478

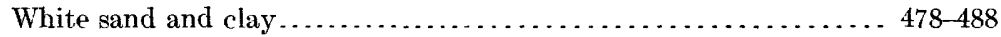

Very hard shell rock............................... 488-489

White water-bearing sand; first flow ..................... 489-494 
Hard white clay

Feet.

Soft white clay.

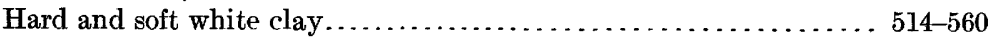

Hard white clay .................................... $560-590$

Quicksand.......................................... 590-611

Hard clay........................................ 611-620

Soft clay,.......................................... $620-631$

Hard and soft clay ................................... 631-703

Sand and clay ......................................... $703-735$

Hard white clay ..................................... $735-740$

Sand, water bearing................................. $740-868$

Hard red clay ...................................

Artesian wells in Galveston County.

\begin{tabular}{|c|c|c|c|c|}
\hline Owner. & Depth. & $\begin{array}{l}\text { Flow per } \\
\text { minute. }\end{array}$ & $\begin{array}{l}\text { Diame- } \\
\text { ter. }\end{array}$ & Location. \\
\hline D. Collogue.. & $\begin{array}{l}\text { Feet. } \\
640\end{array}$ & $\begin{array}{r}\text { Gallons. } \\
200\end{array}$ & Inches. & Dickinson. \\
\hline W. H. Crawford. & 675 & $(a)$ & 8 & Dickinson, 1 mile east. \\
\hline J. D. Ward........ & 700 & & 6 & Dickinson, $2 \frac{1}{2}$ miles east. \\
\hline $\begin{array}{l}\text { C. C. Pellit...... } \\
\text { F. Fonts...... }\end{array}$ & $\begin{array}{l}620 \\
600\end{array}$ & $\begin{array}{r}4 \\
10\end{array}$ & $\begin{array}{l}6 \\
6\end{array}$ & $\begin{array}{l}\text { Dickinson, } 2 \text { miles east. } \\
\text { Dickinson, } 1 \text { mile south. }\end{array}$ \\
\hline John Williains & 750 & (b) & 6 & Dickinson, 2 miles north. \\
\hline Sam Saloets.... & 550 & 2 & & Dickinson, $\frac{1}{2}$ mile northeast. \\
\hline Charles Engelke. & 700 & (a) & & Dickinson, $1 \frac{1}{2}$ miles east. \\
\hline Mick Weeks... . . & 675 & 100 & & Dickinson, $\frac{1}{4}$ mile south west. \\
\hline Joe Lohit.. & 640 & 100 & & Dickinson, \\
\hline Do... & 640 & 100 & & Do. \\
\hline Do...... & 640 & 100 & .... & Do. \\
\hline Charles Nolan. & 600 & & & Dickinson, 1 mile south. \\
\hline Do....... & 650 & & & Dickinson, $2 \frac{1}{2}$ miles south. \\
\hline C. H. Collier .... & & & & Dickinson, $\frac{1}{4}$ mile south. \\
\hline $\begin{array}{l}\text { Nicolini........ } \\
\text { R. A. Walker... }\end{array}$ & $\begin{array}{l}640 \\
750\end{array}$ & 40 & & League City. \\
\hline A. W. Wilkerson. & 550 & 40 & & Do. \\
\hline $\begin{array}{r}\text { Do.............. } \\
\text { J. C. League..... }\end{array}$ & $\begin{array}{l}530 \\
526\end{array}$ & $\begin{array}{l}40 \\
40\end{array}$ & $\cdots \cdot$ & $\begin{array}{l}\text { Do. } \\
\text { Do. }\end{array}$ \\
\hline C. R. Reifel... & 562 & 25 & & Do. \\
\hline Do & 410 & 25 & & Do. \\
\hline Mrs. L. Cours. & 420 & 20 & & Do. \\
\hline Mrs. R. T. Wheeler & 690 & 57 & 2 & Hitchcock, $\frac{1}{2}$ mile east. ' \\
\hline A. म. Tacquard.... & $\begin{array}{l}763 \\
406\end{array}$ & $\begin{array}{l}80 \\
80\end{array}$ & $\begin{array}{l}3 \\
4 \\
4\end{array}$ & $\begin{array}{l}\text { Hitchcock, } \frac{1}{4} \text { mile north. } \\
\text { Hitchcock, } 8 \text { miles west. }\end{array}$ \\
\hline Do.......... & 300 & 25 & $3^{2}$ & \\
\hline Do.. & 306 & 30 & 2 & Hitchcock, 6 miles west. \\
\hline Do.. & 60 & 10 & 2 & Hitchcock, 7 miles west. \\
\hline Do.. & 88 & 12 & 2 & Hitchcock, 8 miles west. \\
\hline Do........... & 88 & 12 & 2 & Do. \\
\hline Jacques Tacquard & 763 & 25 & 3 & Do. \\
\hline & 180 & 15 & $\mathbf{2}$ & Do. \\
\hline A. H. Tacquard ho & 710 & 100 & $\overline{\mathbf{3}}$ & Hitchcock, $1 \frac{1}{2}$ miles west. \\
\hline A. H. Taequard (pa & 720 & 80 & $\mathbf{3}$ & $\begin{array}{l}\text { Hitchcock, } 2 \text { miles south- } \\
\text { west. }\end{array}$ \\
\hline Jules Perthius... & 230 & 25 & 3 & Hitchcock, 2 miles east. \\
\hline w. ${ }_{\text {F }}^{\text {Do }}$ Reitmeyer........... & 495 & 65 & 3 & Do. \\
\hline W. F. Reitmeyer... & 433 & 10 & 2 & Hitcheock, $1_{2}^{1}$ miles west. \\
\hline J. Jinsen.............. & 500 & $\begin{array}{l}80 \\
48\end{array}$ & $\begin{array}{l}3 \\
3\end{array}$ & Hitcheock, 1 mile east. \\
\hline J. A. Minot ... & 763 & 64 & 2 & Hitcheock, $\frac{1}{2}$ mile south. \\
\hline David Tahey & 576 & 68 & 3 & Hitchcock, $1 \frac{1}{2}$ miles east. \\
\hline B. F. Fast. & 702 & 120 & 3 & Hitchcock, $2 \frac{1}{2}$ miles west. \\
\hline Gulf, Colorado and Santa Fe I & 720 & 78 & 3 & Hitchcock, 100 yards east. \\
\hline $\begin{array}{l}\text { J. H. Kemper................... } \\
\text { Alta Loma Co.............. }\end{array}$ & $\begin{array}{l}600 \\
914\end{array}$ & $\begin{array}{l}60 \\
40\end{array}$ & $\begin{array}{l}3 \\
3\end{array}$ & $\begin{array}{l}\text { Hitchcock, } 1 \text { mile enst. } \\
\text { Hitcheock, } 4 \text { miles north- }\end{array}$ \\
\hline Galveston, Houston and Henderson R. R... & 867 & 700 & 10 & $\begin{array}{l}\text { west. } \\
\text { Hitchcock, } 4 \text { miles east, at }\end{array}$ \\
\hline & & & & La Marque. \\
\hline Galveston, Houston and Northern $\mathrm{R}$. $\mathrm{R}$.... & 600 & 50 & $\begin{array}{l}4 \\
3\end{array}$ & Bay View. \\
\hline 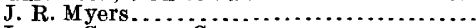 & 725 & 70 & $4 \frac{1}{2}$ & Texas City. \\
\hline Inman Compress Co... & 912 & 70 & 4⿳亠二口⿱幺小 & Do. \\
\hline South Galveston Land Co............. & 640 & 40 & 3 & Middle of island. \\
\hline Do $\ldots \ldots \ldots \ldots \ldots \ldots$ & 644 & 40 & 3 & \\
\hline Galveston Brewing Co. & 872 & Flows. & 8 & \\
\hline
\end{tabular}


Record of deep well at Galveston.

Pleistocene:

Feet.

Gray to buff sand...

0- 46

Reddish-brown clay containing lenses of sandstone, quartz pebbles, nodules of dark-gray clay, and shell fragments ..... 46- 63

Mottled red and blue clay containing shell fragments and in lower part lignitic material ......................... $63-100$

Gray sandy clay ............................... 100-110

Fine gray sand with fragments of lignite. . . . . . . . . . . . 110-167

Buff-colored sandy clay ............................ 167-279

Fine gray sand with fragments of lignite............. 279-305

Grayish-brown clay with fragments of lignite............. . . 305-315

Fine sand, gray to buff, with fragments of lignite throughout bed and lower 35 feet slightly micaceous. . ............. 315-440

Grayish-brown clay with fragments of lignite, shells, corals, and claw of crustacean . . . . . . . . . . . . . . . . . . . . . 440-458

Age doubtful:

Gray sandy clay, slightly micaceous . . . . . . . . . . . . . . 458-468

Brownish-gray sandy clay ........................ $468-497$

Fine light-gray clayey sand, micaceous.............. 497-575

Brownish-gray sandy clay . . . . . . . . . . . . . . . . . 575-592

Gray sand, micaceous......................... 592-612

Brownish sandy clay with shell fragments. . . . . . . . . . . . 612-647

Light-gray sandy clay........................... 647-674

Reddish-brown sandy clay with shell fragments .......... 674-706

Buff-colored sand, slightly miraceous . .................. $706-720$

Brownish-gray clayey sand ....................... $720-737$

Light-gray clayey sand, the lower 11 feet containing a few shell fragments and large pieces of lignite . . . . . . . . . . . 737-827

Coarse silver-gray sand, composed of angular fragments of translucent and smoky quartz not much water-worn (the waterbearing sand from which most of the city's water supply was derived previous to the utilization of the Alta Loma wells)... 827-882

This well was drilled to a depth of 3,070 feet, but practically no water-bearing sand of importance was found below 882 feet. The complete record is published in the Twenty-first Annual Report of the U. S. Geological Survey, part 7, pages 402-405.

\section{CHAMBERS COUNTY.}

Shallow wells.-Beneath the surface soil in Chambers County there is a bed of sand which extends to a depth of 30 feet or more. In its lower part this sand contains an abundance of excellent water which is the source of supply for all shallow wells in the region.

Artesian wells.-There are 17 artesian wells in Chambers County and their approximate location is indicated in Pl. II. At many places artesian water has been obtained, but it is salty in many cases, especially in wells near the bay. 
Artesian wells in Chambers County.

\begin{tabular}{|c|c|c|c|}
\hline Owner. & Depth. & $\begin{array}{l}\text { Flow per } \\
\text { minute. }\end{array}$ & Location. \\
\hline 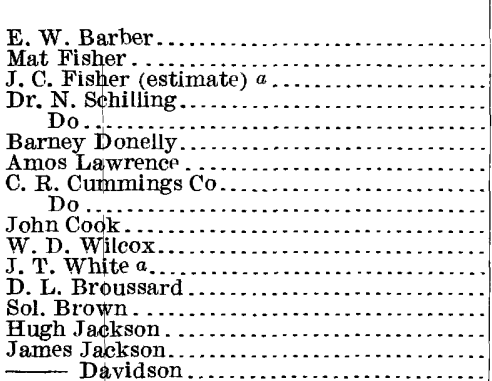 & $\begin{array}{r}\text { Feet. } \\
800 \\
550 \\
500 \\
700 \\
700 \\
375 \\
500 \\
400 \\
400 \\
380 \\
850 \\
1,720 \\
850 \\
800 \\
1,000 \\
600\end{array}$ & $\begin{array}{l}\text { Gallons. } \\
\text { Flows. } \\
\text { Flows. } \\
\text { Flows. } \\
\text { Flows. } \\
\text { Flows. } \\
\text { Flows. } \\
\text { Flows. } \\
\text { Flows. } \\
\text { Flows. } \\
\text { Flows. } \\
35 \\
\text { Flows. } \\
100 \\
100 \\
100 \\
100 \\
100\end{array}$ & $\begin{array}{l}\text { Mount Belvieu. } \\
\text { Mount Belvieu, } 10 \text { miles south. } \\
\text { Cedar Bayou. } \\
\text { Do. } \\
\text { Do. } \\
\text { Mount Belvieu, } 3 \text { miles south. } \\
\text { Mount Belvieu, } 5 \text { miles south. } \\
\text { Anahuac, } 4 \text { miles north. } \\
\text { Do. } \\
\text { Wallisville. } \\
\text { Anahuac, Turtle Bayou. } \\
\text { Double Bayou. } \\
\text { Do. } \\
\text { Double Bayou, } 15 \text { miles southeast. } \\
\text { Double Bayou, } 15 \text { miles northeast. } \\
\text { Near Stowell. }\end{array}$ \\
\hline
\end{tabular}

a Water salty.

\section{JEFFERSON COUNTY.}

Shallow wells.-The wells of.Jefferson County are very shallow, ranging from 6 to 15 feet in depth. Many of those 6 feet deep furnish an abundance of water.

Artesian wells.--Information has been obtained of about 31 artesian wells in this county, but such wells are not generally successful. Many of them have feeble flows, making it necessary to employ pumps to increase the discharge, while in other cases, where the flows are sufficiently large, the water is more or less salty. A large number of wells have been drilled for oil in the vicinity of Spindletop, south of Beaumont. The following is a list of artesian wells in Jefferson County, with other data concerning them. A record of the Stribling well is also given.

Artesian wells in Jefferson County.

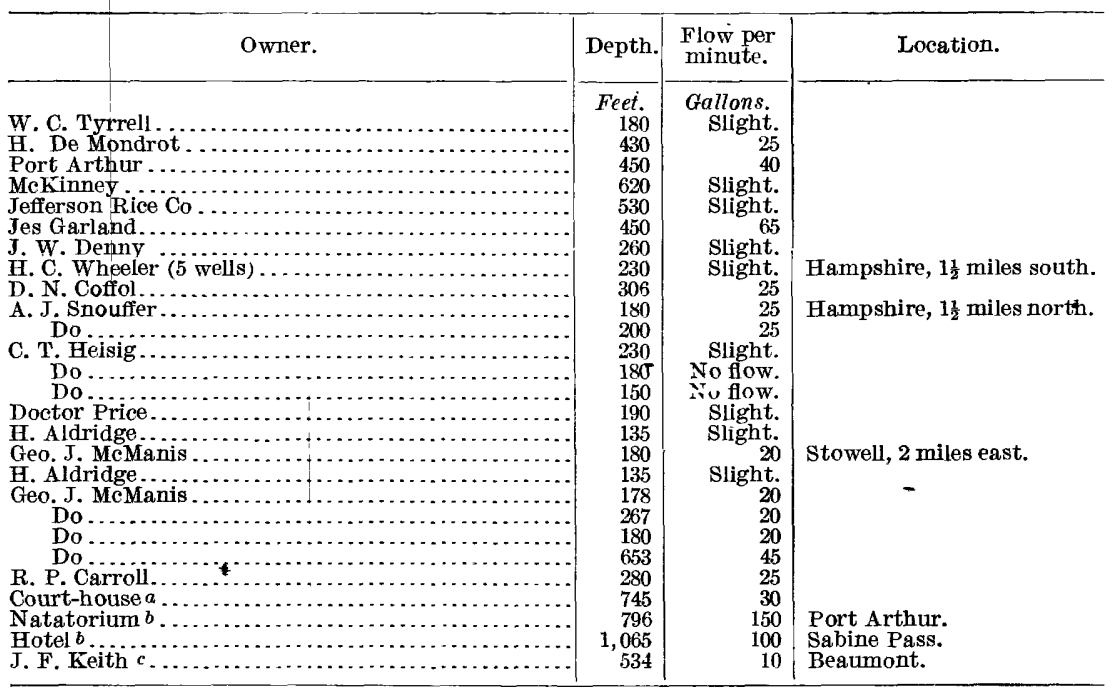




\begin{tabular}{|c|c|}
\hline \multicolumn{2}{|l|}{ Record of Stribling well, Sabine Pass, Jefferson County. } \\
\hline & $0-$ \\
\hline & $16-$ \\
\hline & $20-$ \\
\hline & $60-\quad 80$ \\
\hline & $80-\quad 140$ \\
\hline and $\ldots \ldots \ldots \ldots \ldots$. & $140-170$ \\
\hline aу $\ldots \ldots \ldots \ldots \ldots \ldots \ldots \ldots \ldots \ldots \ldots$ & $170-$ \\
\hline & $185-$ \\
\hline & 220 \\
\hline & $236-$ \\
\hline & 250 \\
\hline & 260 \\
\hline & 270 \\
\hline & $355-$ \\
\hline & $426-$ \\
\hline $\mathrm{y}, \ldots \ldots \ldots \ldots \ldots \ldots$ & $442-$ \\
\hline & $500-$ \\
\hline & $600-$ \\
\hline & $636-$ \\
\hline & $740-$ \\
\hline lors............ & 764 \\
\hline & $795-$ \\
\hline . & $796-$ \\
\hline & $854-$ \\
\hline & $855 \frac{1}{2}-$ \\
\hline & $892-$ \\
\hline & $893-960$ \\
\hline & $960-1,000$ \\
\hline & $1,000-1,260$ \\
\hline & $1,260-1,270$ \\
\hline & $1,270-1,360$ \\
\hline & $1,360-1,450$ \\
\hline & $1,450-1,490$ \\
\hline & \\
\hline
\end{tabular}

\section{ORANGE COUNTY.}

Shallow wells.-The deepest of the shallow wells of Orange County are about 22 feet in depth, and a large supply of water is usually obtained.

Artesian wells.-There are a few artesian wells at Orange, varying in depth from 400 to 800 feet. Their flows are moderate, but few exceeding 50 gallons a minute. A partial list of these wells is given below: 
Artesian wells in Orange County.

\begin{tabular}{|c|c|c|c|c|}
\hline Owner. & Depth. & $\begin{array}{l}\text { Flow per } \\
\text { minute. }\end{array}$ & $\begin{array}{c}\text { Diame- } \\
\text { ter. }\end{array}$ & Location. \\
\hline 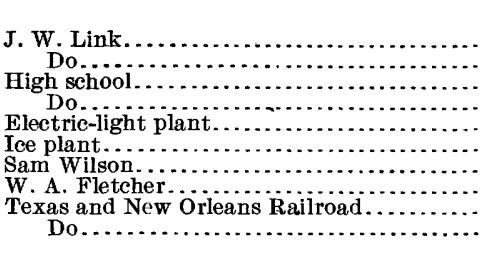 & $\begin{array}{r}\text { Feet. } \\
600 \\
467 \\
467 \\
500 \\
650 \\
480 \\
800 \\
740 \\
396 \\
435\end{array}$ & $\begin{array}{r}\text { Gallons. } \\
15 \\
21 \\
22 \\
10 \\
52 \\
\text { Slight. } \\
60 \\
35\end{array}$ & 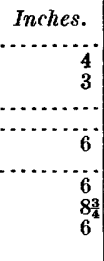 & $\begin{array}{l}\text { Orange. } \\
\text { Do. } \\
\text { Do. } \\
\text { Do. } \\
\text { Do. } \\
\text { Do. } \\
\text { Orange, } 9 \text { miles northwest. } \\
8 \text { miles from Beaumont. } \\
\text { Echo. } 1 \text { mile from Sabine } \\
\text { Echo, } 1 \text { miver. }\end{array}$ \\
\hline
\end{tabular}

\section{ZAPATA COUNTY.}

Shallow wells.-Shallow wells are difficult to obtain in the northern part of Zapata County. Near the Rio Grande and along the eastern part of the county water can be obtained at moderate depths, but in the lower lands the depths of the wells vary from 100 to 250 feet.

Artesian wells.-No information has been received concerning the artesian conditions of this county.

\section{DUVAI COUNTY.}

Shallow wells.-Wells in Duval County can be obtained at depths varying from 50 to 300 feet.

Artesian wells.-No artesian wells have been reported from Duval County. Artesian water is found, however, in the southern part of Nueces County, in the northeastern part of Starr County and at Bruniville, on the Texas and Mexican Railroad, in the eastern part of Webb County. The northern part of Duval County lies between two artesian districts; that at Kingsville, Nueces County, and that at Artesia, Lasalle County. Artesian water is also obtained in the region about 30 miles north of the northern boundary of Duval County.

\section{LIVE OAK COUNTY.}

Shallow wells.- Shallow-well water is obtained in the southern and eastern parts of Live Oak County, at depths of 100 to 120 feet; in the western part at about 200 feet, and in the northern part at 300 feet. 
Artesian wells.-Artesian water is found in the northern part of this county. The following table gives a list of the artesian wells:

Artesian wells in Live Oak County.

\begin{tabular}{|c|c|c|c|}
\hline Owner. & Depth. & Flow. & Location. \\
\hline Geo. W. West. . & $\begin{array}{c}\text { Feet. } \\
155\end{array}$ & Slight .. & Oakville, 13 miles north west. \\
\hline 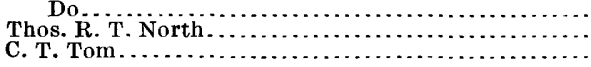 & $\begin{array}{l}226 \\
375 \\
450\end{array}$ & $\begin{array}{l}\text { Slight ... } \\
\underset{(a)}{\text { Small... }}\end{array}$ & $\begin{array}{l}\text { Oakville. } \\
\text { Oakville, } 18 \text { miles north- }\end{array}$ \\
\hline Mrs. B. McGloin...... & 150 & Flows... & Near Mikeska. \\
\hline
\end{tabular}

a Water at 6 feet below surface.

\section{BEE COUNTY.}

Shallow wells.-In the northern and southern parts of Bee County wells have an average depth of about 40 feet, in the eastern part about 70 feet, and in the western part about 100 feet.

Artesian wells.-No information has been obtained regarding the artesian condition of this county. There are at present no artesian wells in Bee County.

\section{GOLIAD COUNTY.}

Shallow wells. - In Goliad County water is found in shallow wells at depths varying from 50 to 125 feet.

Artesian wells.- There are no artesian wells in this county. On the ranch of T. M. O'Connor, 6 miles south and 20 miles east of Goliad, on the head of Little Carco Creek, a boring was made to a depth of 1,446 feet, but no artesian water was obtained.

\section{KARNES COUN'TY.}

Shallow wells. - In Karnes County a good supply of water is obtained from shallow wells having the following average depths: In the northern part, 60 feet; in the eastern part, 80 feet; in the southern part, 90 feet; in the western part, 120 feet.

Artesian wells.- There are at present no artesian wells in Karnes County. At Karnes City a test well was sunk to a depth of 1,800 feet, but no artesian water was found. It is possible that more extensive prospecting in other parts of the county may result in the discovery of flows at shallower depths.

\section{DEWITT COUNTY.}

Shallow wells.-Throughout Dewitt County shallow wells are obtained at an average depth of about 55 feet. The principal water supply appears to lie in sheets, so that the depths of the wells vary according to the elevation of the surface. 
Artesian wells.-The only artesian water thus far obtained in Dewitt County is at Yorktown and Yoakum. At Yorktown there were formerly 8 or 10 small artesian wells, flowing 5 gallons a minute and varying in depth from 50 to 60 feet, but at present only two of these flow, the others having been allowed to cave in or to become choked with sand at the bottom. The two wells which continue to flow are in the bed of Yorktown Creek. Many of the wells in the town show a strong artesian tendency, the water rising within 10 feet of the surface. At Yoakum several deep wells have been drilled and in nearly every case the water rises within a few feet of the surface, but no wells are recorded in which flows were obtained: In the deepest well, 1,300 feet deep, the water is soft, relatively pure, and admirably suited for general domestic uses. It is noncorrosive and well adapted to boiler purposes. According to some analyses it contains only 42 grains of solid matter per gallon and no organic matter.

Record of H. G. Brown's artesian well, $7 \frac{1}{2}$ miles southwest of Cuero, Dewitt County.

\begin{tabular}{|c|c|}
\hline & Feet. \\
\hline Red and yellow clay, with cobblestone...... & $0-$ \\
\hline Hard rock, fine grained................... & $60-$ \\
\hline Water-bearing sand........... & $120-$ \\
\hline 1 and clay, hardpan.. & $121-$ \\
\hline Very hard gritty rock.... & $181-$ \\
\hline Sandstone. & $202-$ \\
\hline rock............ & $365-$ \\
\hline 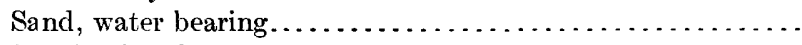 & $490-$ \\
\hline & $690 \frac{1}{2}-710$ \\
\hline 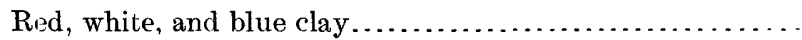 & $710-805$ \\
\hline Talc," with an occasional layer of red and blue clay........ & $805-1.050$ \\
\hline ale-blue "talc;" strong indications of water.............. . & $1,050-1,100$ \\
\hline
\end{tabular}

\section{GONZALES COUNTY.}

Shallow wells. - The shallow wells of Gonzales County show considerable variation in depth, ranging from 20 to 80 feet.

Artesian wells.-In the western part of Gonzales County the artesian water resources have been extensively developed. There are 125 artesian wells in the vicinity of Leesville, Rancho, and Wrightsboro. They vary considerably in depth, ranging from 100 to 70.0 feet, and their maximum flow is 100 gallons a minute. The average flow, however, is much less than this, as shown in the following table, which contains a partial list of these wells, with their depth, flow, and approximate location. 
Artesian wells in Gonzales County.

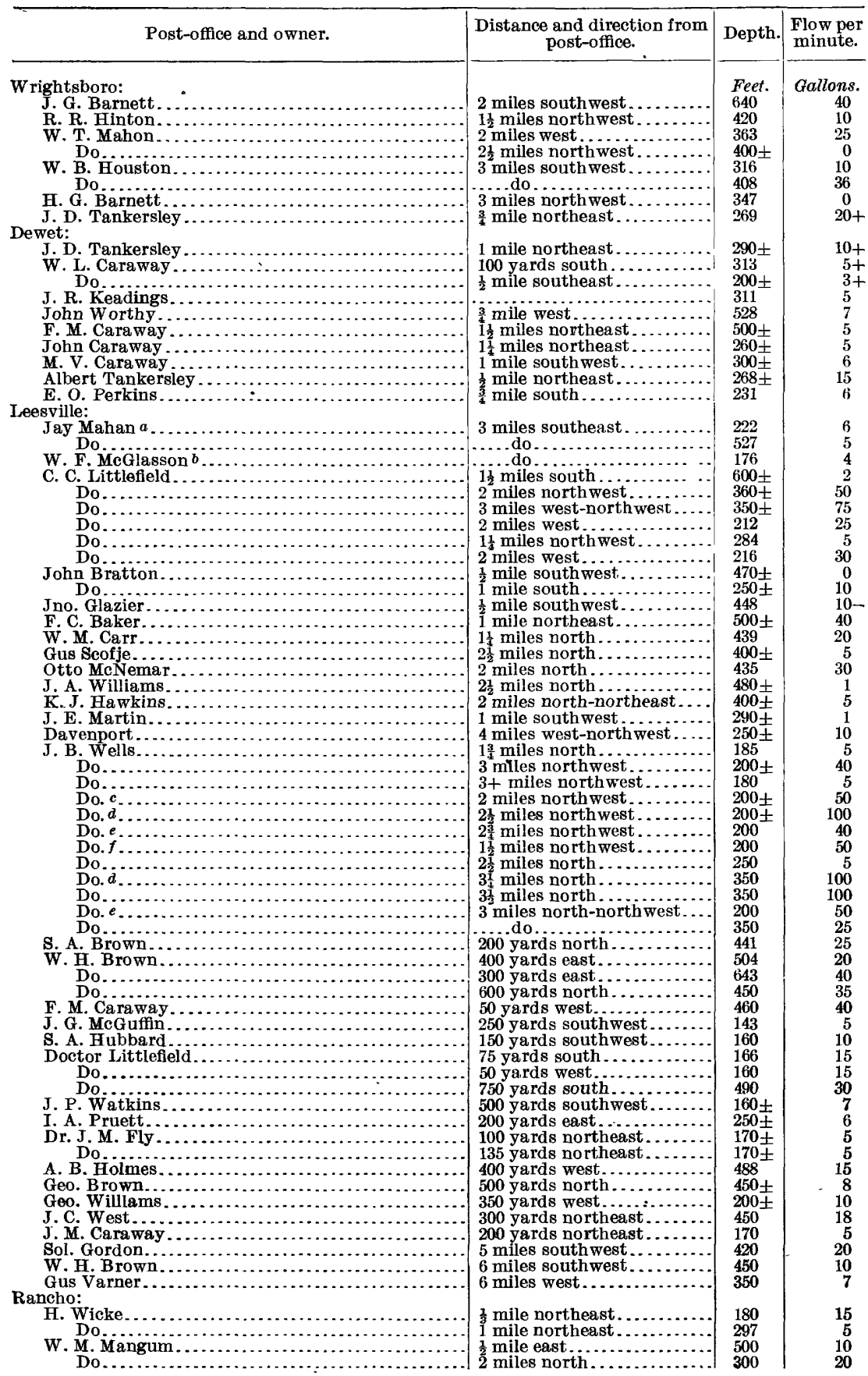

$a$ First water at 135 feet: second at 222 . $b$ Four wells with 4-inch pipe casing. c Casing, 3-inch pipe. $d$ First water.

$e$ Casing, 6-inch pipe. $f$ Casing, 4-inch pipe. 
Artesian wells in Gonzales County-Continued.

\begin{tabular}{|c|c|c|c|}
\hline Post-office and owner. & $\begin{array}{l}\text { Distance and direction from } \\
\text { post-office. }\end{array}$ & Depth. & $\begin{array}{l}\text { Flow per } \\
\text { minute. }\end{array}$ \\
\hline 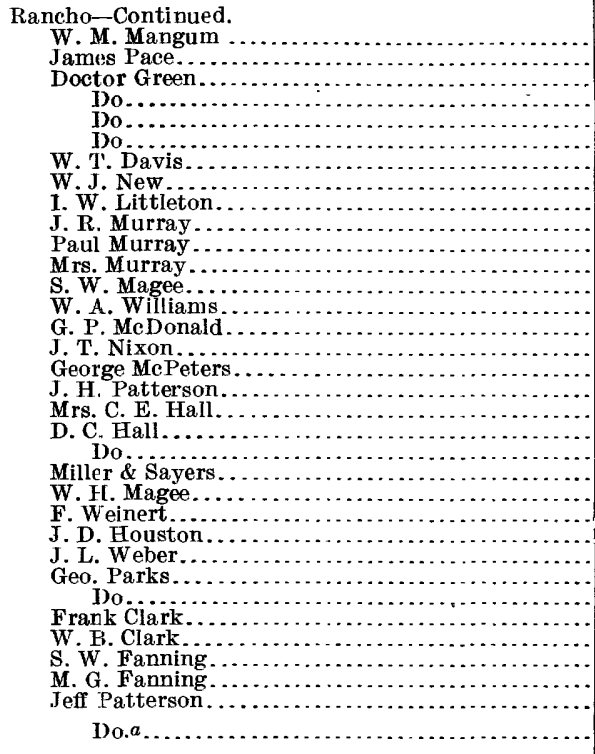 & 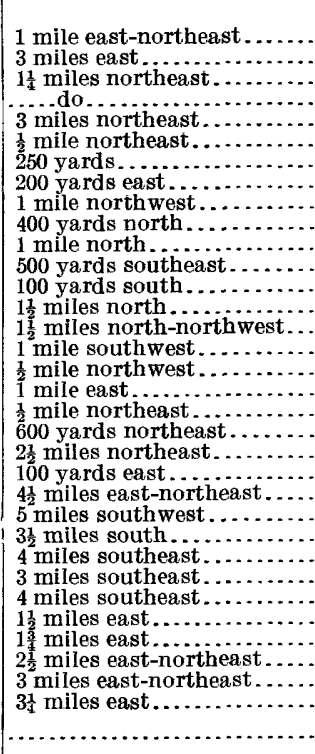 & $\begin{array}{l}\text { Feet. } \\
185 \\
360 \\
420 \\
175 \\
400 \\
325 \\
509 \\
450 \\
140 \\
130 \\
180 \\
230 \\
475 \\
300 \\
280 \\
400 \\
117 \\
270 \\
300 \\
350 \\
450 \\
385 \\
430 \\
406 \\
420 \\
537 \\
531 \\
505 \\
400 \\
300 \\
260 \\
225 \\
337 \\
450 \\
700\end{array}$ & $\begin{array}{r}\text { Gallons. } \\
30 \\
5 \\
20 \\
10 \\
12 \\
15 \\
10 \\
6 \\
10 \\
4 \\
10 \\
5 \\
15 \\
5 \\
5 \\
6 \\
7 \\
10 \\
1 \\
25 \\
10 \\
20 \\
15 \\
10 \\
15 \\
3 \\
40 \\
30 \\
7 \\
5 \\
15 \\
13 \\
6 \\
25 \\
10\end{array}$ \\
\hline
\end{tabular}

a This well has two casings, one inside the other. The outer is 450 feet deep and furnishes salt water (25 gallons) and gas. The inner is 700 feet deep and furnishes good water.

The following is the record of a representative artesian well, situated on the Gentry ranch', on Sandy Fork of Peach Creek, 12 miles northeast of Gonzales.

\section{Record of Charles Gentry's artesian well, Gonzales County.}

Clay and flint bowlders.

Feet.

Rock

Blue sand and clay

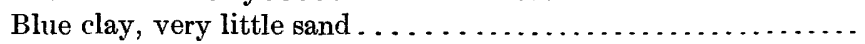

Hard sandstone, fine grained (10 inches of water sand at this

depth; trace of oil; lignite plentiful) ................... $157-195$

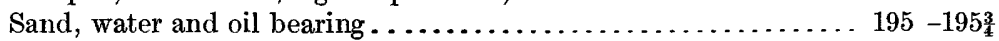

White quartz . . . . . . . . . . . . . . . . . . . . . . . . . . . . . 195 $195^{\frac{3}{4}}-196 \frac{1}{2}$

Sandstone. nard, fine grained (trace of oil) $\ldots \ldots \ldots \ldots \ldots \ldots \ldots . . \ldots \ldots 6 \frac{1}{2}-218$

Blue clay ..................................... $218-220$

Sandstone (trace of oil) . . . . . . . . . . . . . . . . . . . . . $220-222$

Black clay, containing decayed wood . . . . . . . . . . . . . . $222-228$

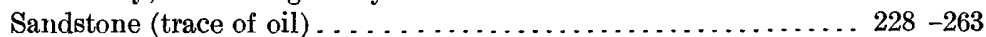

Blue marl. . . . . . . . . . . . . . . . . . . . . . . . . . . . . $263-285$

Quartz....................................... . $285-286$

Blue marl, spongy . . . . . . . . . . . . . . . . . . . . . . . . . . . . . $286-304$

Shale with soft strata . . . . . . . . . . . . . . . . . . . . . . . . . $304-321$

Hard blue sandstone ................................ 321 -339 


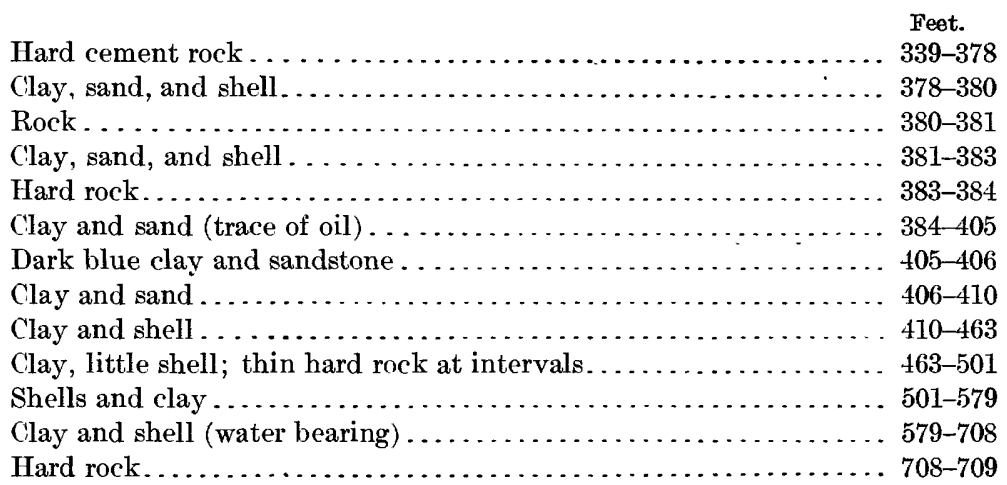

\section{IAA ACA COUNTY.}

Shallow wells.-An abundance of water is obtained in Lavaca County from wells which vary in depth from 30 to 40 feet.

Artesian wells.-A number of good artesian wells have been obtained in Hallettsville and the surrounding country. In the wells at Hallettsville two flows have been found, one at 300 feet and the other at 560 feet below the surface. The oil-mill well encountered the first flow at 320 feet, which furnished a supply of 45 gallons per minute, while the second flow at a depth of 560 feet furnished 88 gallons a minute. At Shiner a flowing well was obtained at a depth of 90 feet, which yielded 79 gallons a minute. The well was located on low ground and the water rose 6 feet above the surface. Several attempts to obtain water from this horizon on higher ground, in the vicinity of Shiner, have been unsuccessful, one boring being continued to a depth of 700 feet without striking a flow. The following is a list of the artesian wells in this county:

Artesian wells in Lavaca County.

\begin{tabular}{|c|c|c|c|c|}
\hline Owner. & Depth. & $\begin{array}{l}\text { Flow per } \\
\text { minute. }\end{array}$ & $\underset{\text { ter. }}{\text { Diame- }}$ & Location. \\
\hline 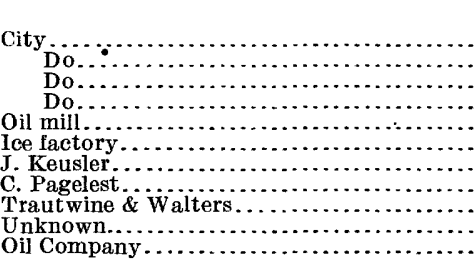 & $\begin{array}{r}\text { Feet. } \\
600 \\
560 \\
325 \\
980 \\
560 \\
340 \\
768 \\
340 \\
90 \\
700 \\
1,500\end{array}$ & $\begin{array}{r}\text { Gallons. } \\
30 \\
89 \\
45 \\
140 \\
30 \\
30 \\
30 \\
30 \\
25 \\
\text { Failure. } \\
\text {...do... }\end{array}$ & $\begin{array}{r}\text { Inches. } \\
4 \\
4 \\
4 \\
4 \\
4 \\
4 \\
4 \\
4 \\
4 \\
-\end{array}$ & $\begin{array}{l}\text { Hallettsville. } \\
\text { Do. } \\
\text { Do. } \\
\text { Do. } \\
\text { Do. } \\
\text { Breslau. } \\
\text { Hallettsville, } 4 \text { miles north. } \\
\text { Shiner. } \\
\text { Do. } \\
\text { Hallettsville, } 7 \text { miles south- } \\
\text { east. }\end{array}$ \\
\hline
\end{tabular}




\section{FAYETTE COUNTY.}

Shallow wells.-Water in sufficient quantity for general domestic purposes is found in the northern and western parts of Fayette County at average depths of 60 feet, in the southern part at depths of 75 to 100 feet, and in the eastern part at depths of 40 to 75 feet.

Artesian wells.-There are 20 artesian wells in this county, including a few deep ones; the area in which the greatest number has been drilled lies north of Engle. The average depth of these wells varies from 200 to 300 feet and the maximum flow is 100 gallons a minute. The following is a list of the wells, including their depth, flow, and other data:

Artesian wells in Fayette County.

\begin{tabular}{|c|c|c|c|c|}
\hline Owner. & Depth. & $\begin{array}{l}\text { Flow per } \\
\text { minute. }\end{array}$ & $\begin{array}{c}\text { Diame- } \\
\text { ter. }\end{array}$ & Location. \\
\hline 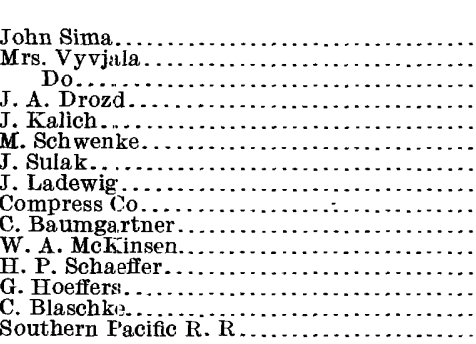 & $\begin{array}{r}\text { Feet. } \\
196 \\
216 \\
220 \\
210 \\
210 \\
185 \\
165 \\
200 \\
260 \\
258 \\
267 \\
300 \\
275 \\
300 \\
762\end{array}$ & $\begin{array}{r}\text { Gallons. } \\
25 \\
15 \\
50 \\
10 \\
18 \\
16 \\
10 \\
10 \\
a 40 \\
a 87 \\
a 43 \\
a 79 \\
a 54 \\
a 79 \\
(b)\end{array}$ & $\begin{array}{r}\text { Inches. } \\
3 \\
3 \\
3 \\
3 \\
3 \\
3 \\
3 \\
2 \\
6 \\
6 \\
5 \\
3 \\
3 \\
3 \\
10\end{array}$ & $\begin{array}{l}\text { Praha. } \\
\text { Do. } \\
\text { Do. } \\
\text { Do. } \\
\text { Engle, } 2 \text { miles northwest. } \\
\text { Do. } \\
\text { Do. } \\
\text { Do. } \\
\text { Schulenburg. } \\
\text { Do. } \\
\text { Do. } \\
\text { Do. } \\
\text { Do. } \\
\text { Do. } \\
\text { Do. }\end{array}$ \\
\hline
\end{tabular}

$a$ No flow; water rises to number of feet stated below surface of ground.

$b$ Well caved in.

\section{COLORADO COUNTY.}

Shallow wells.-Shallow wells in Colorado County are about 40 feet deep in the northern and western parts, 35 feet in the southern part, and 30 feet in the eastern part. East of Eagle Lake there are a number of wells 30 to 35 feet deep, which furnish a large supply of good water. Two wells supply water for 100 acres of rice, each acre of which requires 9 gallons a minute, and it is generally believed that a good rice well can be obtained at moderate depths in this county at any point east of Eagle Lake. 
Artesian wells.-So far as known the only artesian well in Colorado County is located on the west bank of Colorado River at Columbus. This well was bored by the city for water supply, and it has maintained a steady but small flow for years. The water contains a small amount of gas. The record of this well is given below:

Record of artesian well at Columbus, Colorado County.

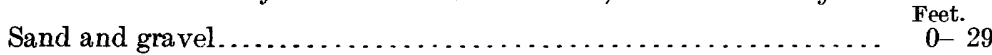

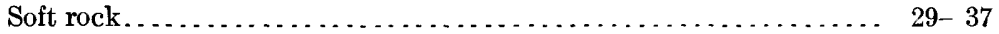

Fine gravel ...................................... $37-41$

Blue gravel...................................... 41-54

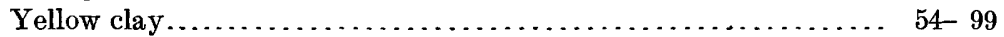

Hard rock ......................................... 99-101

Yellow clay ........................................ 101-104

Conglomerate rock . . . . . . . . . . . . . . . . . . . . . . . . . . . . 104-110

Yellow ciay....................................... 110-190

White sand. water bearing . . . . . . . . . . . . . . . . . . . $190-198$

Yellow clay ........................................ 198-210

Hard bowlders..................................... 210-212

Yellow clay......................................... 212-214

Red sandstone.................................... 214-220

Yellow clay ...................................... 220-221

Soft rock . . . . . . . . . . . . . . . . . . . . . . . . . . . . 221-223

Yellow clay....................................... 223-226

Concrete rock . . . . . . . . . . . . . . . . . . . . . . . . . . . . 226-233

Light-red clay. ................................... 233-280

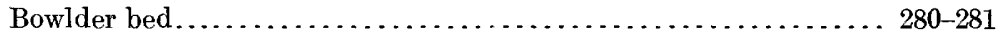

Yellow clay...................................... 281-283

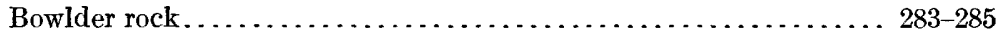

Yellow clay....................................... 285-289

Yellow sandstone . . . . . . . . . . . . . . . . . . . . . . . . . . 289-290

Yellow clay...................................... 290-302

Hard sandstone................................... 302-304

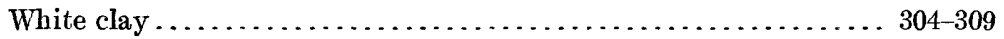

Red sandstone................................... 309-311

Light-yellow clay . . . . . . . . . . . . . . . . . . . . . . . . . 311-319

Yellow sandstone . . . . . . . . . . . . . . . . . . . . . . . . . . . . . . . . 319-321

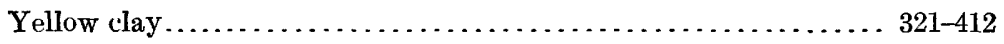

Slate and clay . . . . . . . . . . . . . . . . . . . . . . . . . . . . 412-454

Red, white, and blue clay . . . . . . . . . . . . . . . . . . . . 454-583

Blue sand; flowing water, 8 gallons a minute . . . . . . . . . . 583-600

Hard blue clay .................................6 $600-620$

Fine blue sand; flowing gas. . . . . . . . . . . . . . . . . . $620-633$

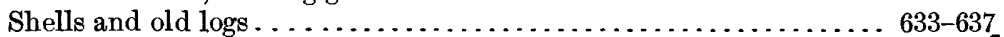

Blue clay ...................................... 637-658

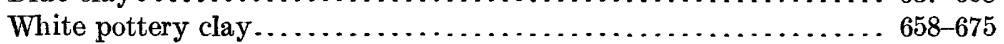

Fine white sand; flowing water........................ 675-683

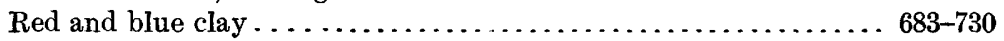

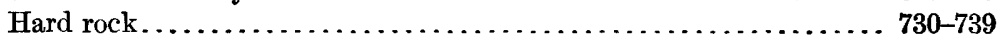

Hard blue clay ...................................... 739-793

Fine blue sand, hard .............................. $793-807$

Fine rock (bored into 19 feet). 


\section{AUSTIN COUNTY.}

Shallow wells.-A good supply of water is obtained from shallow wells in the western part of Austin County at an average depth of 30 feet; in the southern part at 40 feet, in the eastern part at 60 feet, and in the northern part at about 50 feet.

Artesian wells.-No artesian wells have been reported from this county, although it is probable that they can be obtained along Brazos River.

\section{WALLER COUNTY.}

Shallow wells.-In Waller County shallow wells vary in depth from 35 to 50 feet.

Artesian wells.-Only a few artesian wells have been drilled in Waller County, the data of some of which are tabulated below. The most successful free-flowing wells are found near Brazos River.

Artesian wells in Waller County.

\begin{tabular}{|c|c|c|c|c|}
\hline Owner. & Depth. & $\begin{array}{l}\text { Flow per } \\
\text { minute. }\end{array} \mid$ & Diameter. & Location. \\
\hline $\begin{array}{l}\text { Waterworks ... } \\
\text { Heber Stone.... }\end{array}$ & $\begin{array}{r}\text { Feet. } \\
1,132 \\
485\end{array}$ & $\begin{array}{r}\text { Gallons. } \\
110 \\
40\end{array}$ & $\begin{array}{r}\text { Inches. } \\
4_{\frac{1}{2}} \\
1\end{array}$ & $\begin{array}{l}\text { Hempstead. } \\
\text { Hempstead, } 5 \text { miles north- }\end{array}$ \\
\hline $\begin{array}{l}\text { Rufus Hardy } \\
\text { J. C. Ralston } \ldots \ldots \ldots \ldots \ldots \ldots \ldots \ldots \ldots \ldots \ldots \ldots \ldots \ldots\end{array}$ & $\begin{array}{r}850 \\
1,700\end{array}$ & 15 & 1 & $\begin{array}{l}\text { Hempstead, } 6 \text { miles south. } \\
\text { Waller, } 4 \text { miles south. }\end{array}$ \\
\hline
\end{tabular}

\section{WASHINGTON COUNTY.}

Shallow wells.-A good supply of excellent water is obtained in Washington County, at various depths, ranging from 20 to 60 feet.

Artesian wells.-Only a few artesian wells have been drilled in this county, a list of which is given below. It is probable that artesian water can be found in the eastern part of the county, in the Brazos bottom lands, but owing to the excellent supply of water from nonflowing wells few attempts have been made to develop artesian water.

A few years ago Heber Stone had a well drilled in Brenham to a depth of 1,500 feet, but no flowing water was obtained. The water rose in the, well within 40 feet of the surface, and it is believed that wells penetrating the same water horizon in the Brazos bottom lands would yield flows. The city of Brenham derives its water supply from wells between 300 and 400 feet deep. The following is a list of the artesian wells in this county.

Artesian wells in Washington County.

\begin{tabular}{|c|c|c|c|c|}
\hline Owner. & Depth. & Flow. & Diameter. & Location. \\
\hline $\begin{array}{l}\text { J. Balbridge..... } \\
\text { Robert Moore.. }\end{array}$ & $\begin{array}{r}\text { Feet. } \\
640 \\
340\end{array}$ & $\begin{array}{l}\text { Flows... } \\
\text { Flows.. }\end{array}$ & & \multirow{3}{*}{$\begin{array}{l}\text { Gaball, } 300 \text { yards northwest. } \\
\text { Old Washington. } \\
\text { Chapel Hill, } 6 \text { miles north- } \\
\text { east. } \\
\text { Chapel Hill, near. }\end{array}$} \\
\hline J. Po Buchanan... & $\begin{array}{l}700 \\
500\end{array}$ & $\begin{array}{l}\text { Flows... } \\
\text { Strong.. }\end{array}$ & & \\
\hline John Carlisle.. & 560 & Flows... & & \\
\hline
\end{tabular}




\section{GRIMES COUNTY.}

Shallow wells.-Water from shallow wells is obtained in the eastern part of Grimes County at a depth of 30 feet; in the southern part, at 35 feet; in the western part, along the Navasota, at 30 feet, and in the northern part at depths of 50 to 60 feet.

Artesian wells.-Good artesian water is obtained in and around Navasota and between Navasota and Brazos River. The following table shows the artesian wells of Grimes County:

Artesian wells in Grimes County.

\begin{tabular}{|c|c|c|c|c|}
\hline Owner. & Depth. & $\begin{array}{l}\text { Flow per } \\
\text { minute. }\end{array}$ & $\begin{array}{c}\text { Diame- } \\
\text { ter. }\end{array}$ & Location. \\
\hline 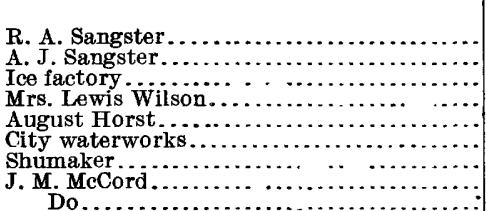 & $\begin{array}{r}\text { Feet. } \\
300 \\
225 \\
250 \\
224 \\
1,000 \\
97 \\
101 \\
850 \\
900\end{array}$ & $\begin{array}{r}\text { Gallons. } \\
60 \\
+15 \\
+20 \\
\ldots . \\
\ldots .\end{array}$ & 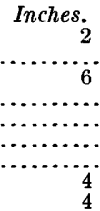 & $\begin{array}{l}\text { Navasota. } \\
\text { Navasota, } \frac{1}{4} \text { mile south. } \\
\text { Navasota. } \\
\text { Do. } \\
\text { Do. } \\
\text { Do. } \\
\text { Court }=y, \frac{1}{4} \text { mile southeast. } \\
\text { Courtsey, mile east. }\end{array}$ \\
\hline
\end{tabular}

Record of Navasota well, Grimes County.

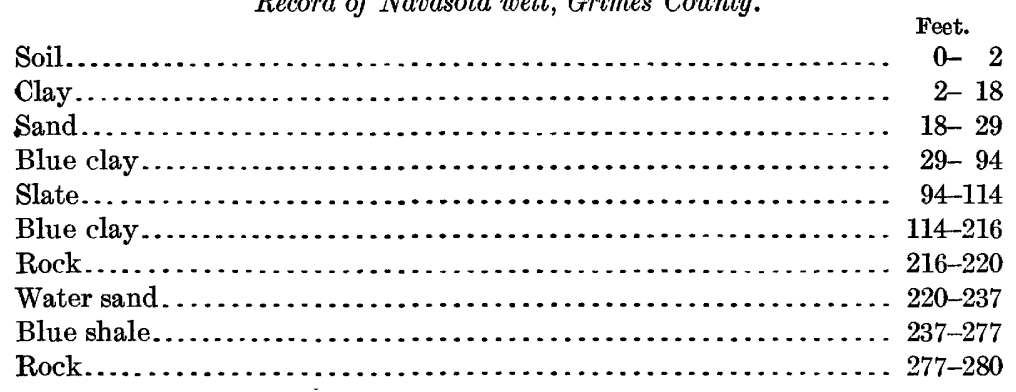

Analysis of water from deep well at Navasota, Grimes County. ${ }^{a}$

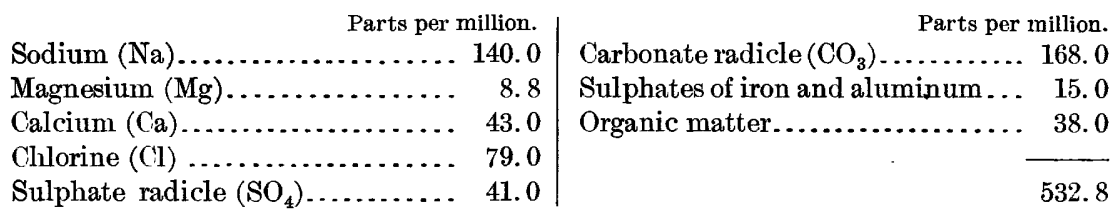

a Expressed by analyst in grains per gallon and hypothetical combinations; recomputed to parts per million and ionic form at U. S. Geol. Survey. 


\section{LIBERTY COUNTY.}

Shallow wells.-Water from shallow wells is secured throughout Liberty County at depths of 15 to 25 feet.

Artesian wells.--The Gulf, Colorado and Santa Fe Railroad has deep wells at Trinity River and Cleveland. Records of these wells and analyses of their waters are given below. The following table contains a list of flowing artesian wells drilled in Liberty County:

Flowing artesian wells in Liberty County.

\begin{tabular}{|c|c|c|c|}
\hline Owner. & Depth. & $\begin{array}{l}\text { Diame- } \\
\text { ter. }\end{array}$ & $\begin{array}{l}\text { Distance and direction from } \\
\text { Liberty. }\end{array}$ \\
\hline 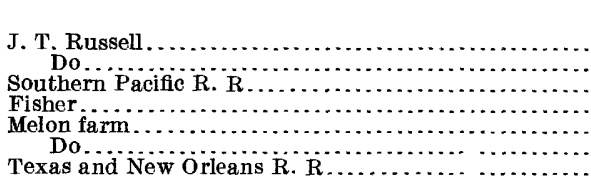 & $\begin{array}{r}\text { Feet. } \\
290 \\
300 \\
800 \\
150 \\
240 \\
245 \\
576\end{array}$ & 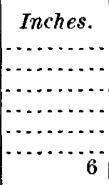 & $\begin{array}{l}\frac{1}{2} \text { mile south. } \\
\frac{3}{3} \text { mile southeast. } \\
300 \text { yards southeast. } \\
1 \text { mile west. } \\
\frac{1}{2} \text { mile south. } \\
\quad \text { Do. }\end{array}$ \\
\hline
\end{tabular}

Record of deep well at Trinity River, Liberty County.

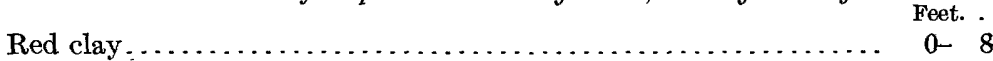

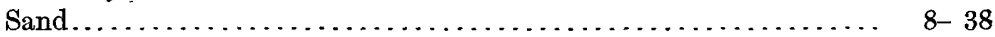

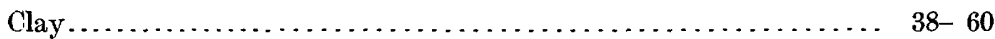

Rock and clay ...................................... 60-104

Quicksand ........................................ 104-117

Rock.......................................... 117-119

Clay............................................ 119-121

Rock..................................... 121-133

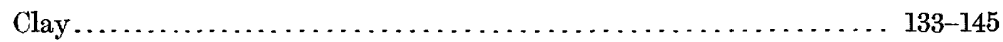

Rock.......................................... 145-151

Coarse sand..................................... 151-163

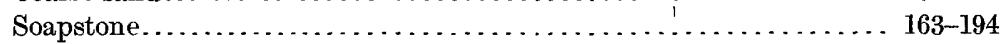

Rock.......................................... 194-196

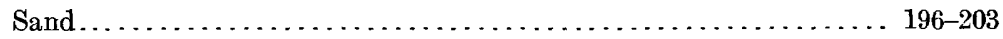

Rock ....................................... 203-210

Clay ........................................... 210-220

Rock........................................ 220-240

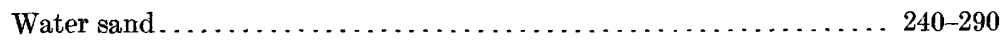

Clay ......................................... 290-300

Analysis of water from deep well at Trnity River, Liberty County. ${ }^{a}$

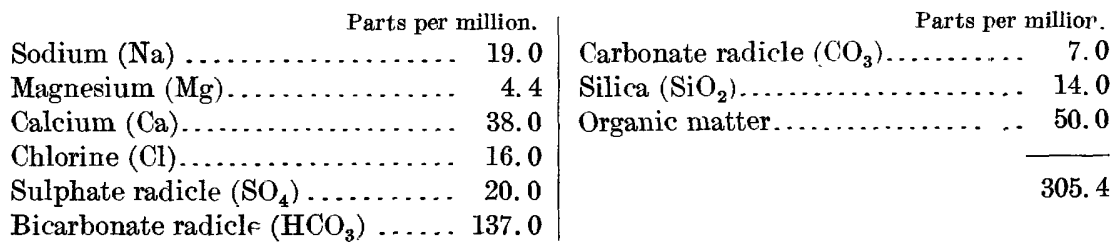

$a$ Expressed by analyst in grains per gallon and hypothetical combinations; recomputed to parts per million and ionjc form at U.S. Geol. Survey. 
Record of deep well at Cleveland, Liberty County.

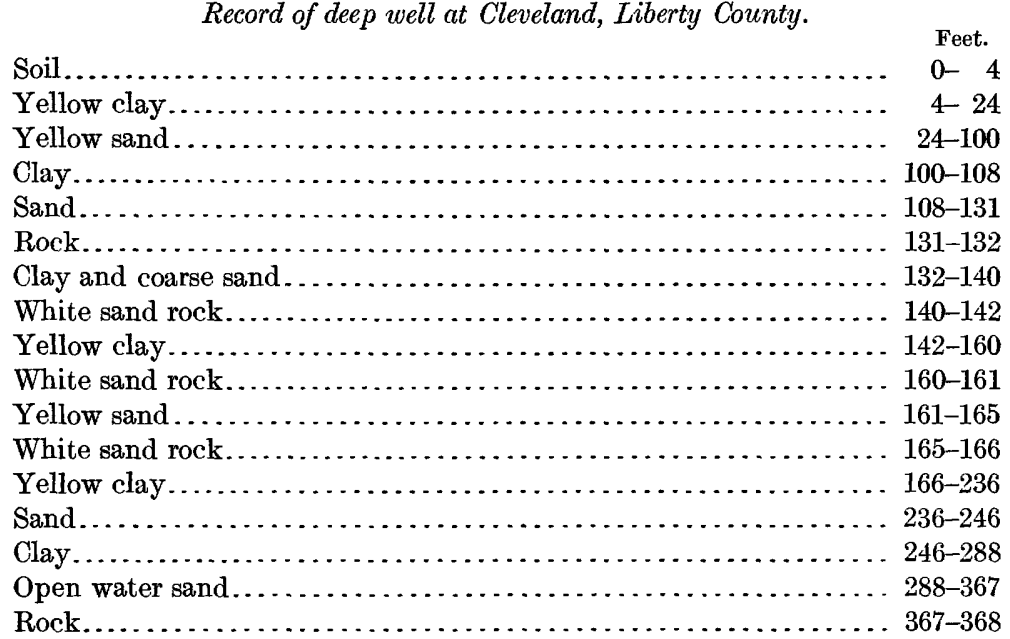

Analysis of water from deep well at Cleveland, Liberty County. ${ }^{a}$

[Analyst, W. A. Powers.]

Parts per million.

Silica $\left(\mathrm{SiO}_{2}\right) \ldots \ldots \ldots \ldots \ldots \ldots \ldots \ldots, 27$

Calcium (Ca)................. 43

Magnesium $(\mathrm{Mg}) \ldots \ldots \ldots \ldots \ldots \ldots . \quad 30$

Sodium $(\mathrm{Na}) \ldots \ldots \ldots \ldots \ldots \ldots \ldots, 12$

Carbonate radicle $\left(\mathrm{CO}_{3}\right) \ldots \ldots \ldots .74$

Sulphate radicle $\left(\mathrm{SO}_{4}\right) \ldots \ldots \ldots \ldots .113$ Carbonic acid combined as $\mathrm{HCO}_{3} \ldots \quad 63$

\section{MONTGOMERY COUNTY.}

Shallow wells.-Shallow wells in Montgomery County vary in depth from 30 to 50 feet.

Artesian wells.-The Gulf, Colorado and Santa Fe Railroad has a deep well at Bobbin and an artesian well at Conroe. Records of these wells and analyses of their waters are given below.

\section{Record of well at Bobbin, Montgomery County.}

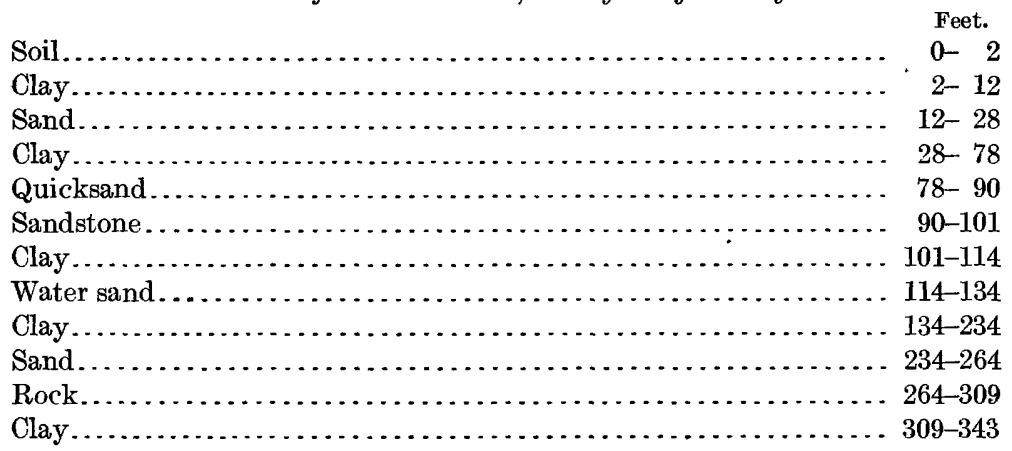

$a$ Expressed by analyst in grains per gallon and hypothetical combinations; recomputed to parts per million and ionic form at U. S. Geol. Survey. 
Feet.

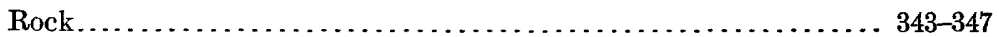

Slate. . . . . . . . . . . . . . . . . . . . . . . . . . . . . . 347-383

Rock. . . . . . . . . . . . . . . . . . . . . . . . . . . . . 383-390

Slate... . . . . . . . . . . . . . . . . . . . . . . . . . . 390-454

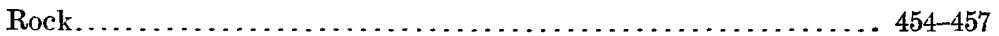

Slate.................................... $457-480$

Analysis of water from deep well at Bobbin, Montgomery County. ${ }^{a}$

Sodium $(\mathrm{Na})$

Magnesium (Mg).

Calcium (Ca) .

Chlorine (Cl)

Sulphate radicle $\left(\mathrm{SO}_{4}\right)$.

Bicarbonate radicle $\left(\mathrm{HCO}_{3}\right) \ldots \ldots . \quad 358$

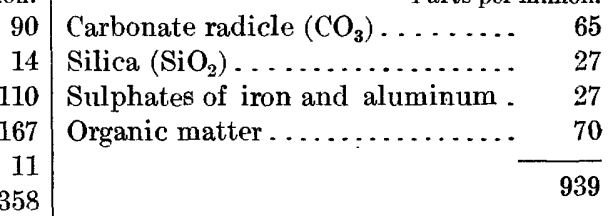

Record of well at Conroe, Montgomery County.

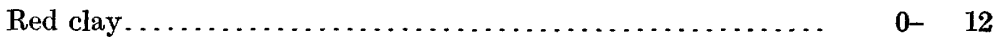

Rock................................. 12- 13

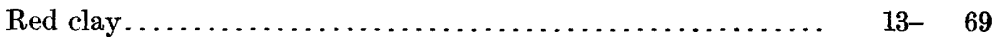

Sand ...................................... 69

Red clay................................ $89-133$

Hard yellow clay............................ 133- 153

Joint clay ........................................ $153-182$

Water sand ................................. 182- 193

Soft clay........................................ 193- 248

Hard clay..................................... 248-265

Rock................................... 265- 267

Hard clay ................................ 267- 280

Rock................................... 280 285

Dry sand bed................................ 285- 297

Clay......................................... 297- 340

Rock..................................... $340-343$

Clay ........................................ $343-363$

Rock...................................... $363-365$

Blue clay..................................... $365-489$

Light clay .................................... $489-500$

Soft clay ...................................... $500-575$

Rock................................. $575-577$

Water sand.............................. 577- 642

Blue clay ....................................... $642-680$

Water sand. .................................. $680-740$

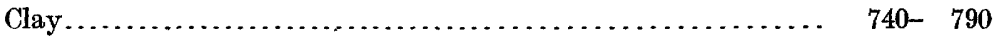

Soapstone.................................... $790-831$

Red clay...................................... $831-888$

Soapstone................................. 888- 924

Clay ........................................ 924-976

Rock................................ 976-978

Clay .................................... 978-1,003

a Expressed by analyst in grains per gallon and hypothetical combinations; recomputed to parts per million and ionic form at U. S. Geol. Survey.

IRR $190-07-4$ 
Rock.

Feet.

Sand $1,003-1,004$

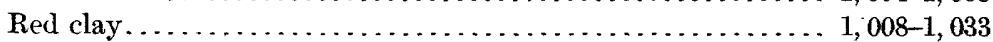

Soapstone.............................

Rock.................................

Sand ...................................... 1,075-1, 125

Soapstone...............................

Rock................................... 1, 169-1,170

Clay.......................................... 1, 170-1, 190

Rock........................................ 1, 190-1, 192

Clay......................................... 1, 192-1, 212

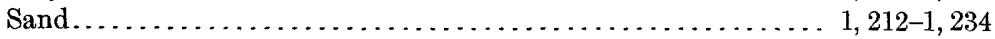

Rock ........................................ 234-1, 236

Analysis of water from deep well at Conroe, Montgomery County. ${ }^{a}$

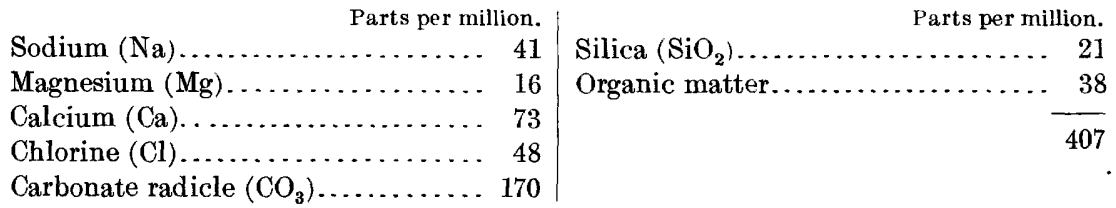

\section{WALKER COUN'TY.}

Shallow wells.-Water is procured from shallow wells in Walker County at depths varying from 35 to 45 feet.

Artesian wells.--There are no artesian wells in Walker county, but it is believed that they could be obtained throughout its area. The numerous flowing streams in the county and the shallow derths at which nonflowing wells may be obtained have decreased the demand for artesian water.

\section{SAN JACINTO COUNTY.}

Shallow wells.-In San Jacinto County shallow wells vary in depth from 35 to 60 feet.

Artesian wells.-There are no artesian wells in this county. At Oakhurst, 7 miles east of Dodge, a well was drilled to a depth of 1,052 feet, penetrating hard rock the greater part of the distance, but no flowing water was obtained. It is generally believed that the prospects for artesian water in this region are very poor.

\section{POLK COUNTY.}

Shallow wells.-The average depth of shallow wells in Polk County is 30 feet.

Artesian wells.--There is little demand for artesian water in Polk County, owing to the numerous small flowing streams and the shallow depths at which nonflowing wells may be obtained.

a Expressed by analyst in grains per gallon and hypothetical combinations; recomputed to parts per million and ionic form at U. S. Geol. Survey 


\section{HARDIN COUNTY.}

Shallow wells.-The shallow wells of Hardin County vary in depth from 15 to 30 feet. The county is well drained by the small flowing streams that empty into Neches River or Pine Island Bayou.

Arteginells. - In this county there is little need for artesian water and cof apently no artesian wells have been drilled. Deep wells are owned by the Santa Fe Railroad at Silsbee, Dies (Kountze post-office), and Votaw. Records of these wells and analyses of their waters are given below.

Record of well at Silsbee, Hardin County.

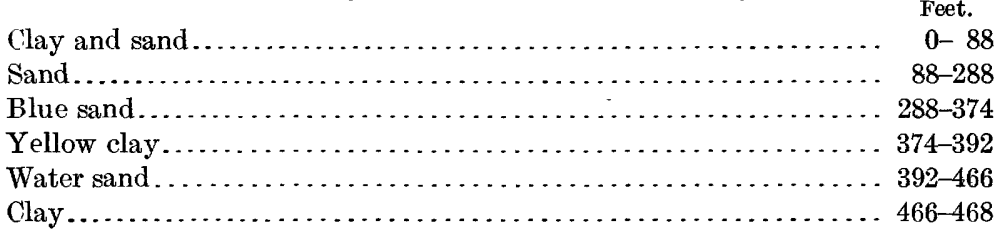

Analysis of water from deep well at Silsbee, Hardın County. ${ }^{a}$

\begin{tabular}{|c|c|c|c|}
\hline \multicolumn{2}{|c|}{ Parts per million. } & \multicolumn{2}{|c|}{ Parts per million. } \\
\hline Sodium (Na) .............. & 24.0 & Carbonate radicle $\left(\mathrm{CO}_{3}\right) \ldots \ldots \ldots$ & 9.5 \\
\hline Magnesium (Mg)....... & 5.9 & Silica $\left(\mathrm{SiO}_{2}\right), \ldots \ldots \ldots \ldots \ldots \ldots$ & 19.0 \\
\hline Calcium (Ca) $\ldots \ldots \ldots \ldots \ldots$ & 36.0 & Organic matter........ & 44 \\
\hline Chlorine $(\mathrm{Cl}) \ldots \ldots \ldots \ldots \ldots \ldots$. & 26.0 & & \\
\hline $\begin{array}{l}\text { Sulphate radicle }\left(\mathrm{SO}_{4}\right) \ldots \ldots \ldots \ldots \\
\text { Bicarbonate radicle }\left(\mathrm{HCO}_{3}\right) \ldots \ldots \ldots\end{array}$ & 15. 0 & & \\
\hline
\end{tabular}

Record of deep well at Dies, Hardin County. a

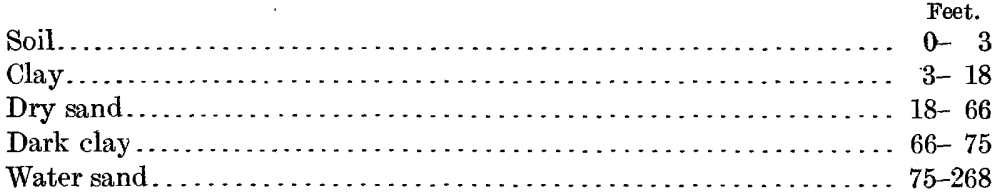

Analysis of water from deep well at Dies, Hardin County. ${ }^{a}$

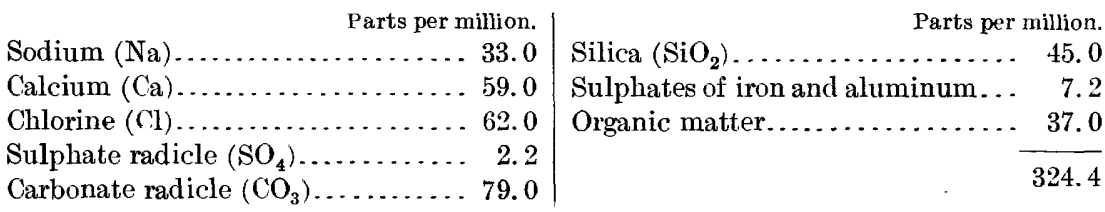

a Expressed by analyst in grains per gallon and hypothetical combinations; recomputed to parts per million and jonic form at U, S. Geol. Survey. 
.Record of well at Votaw, Hardin County.

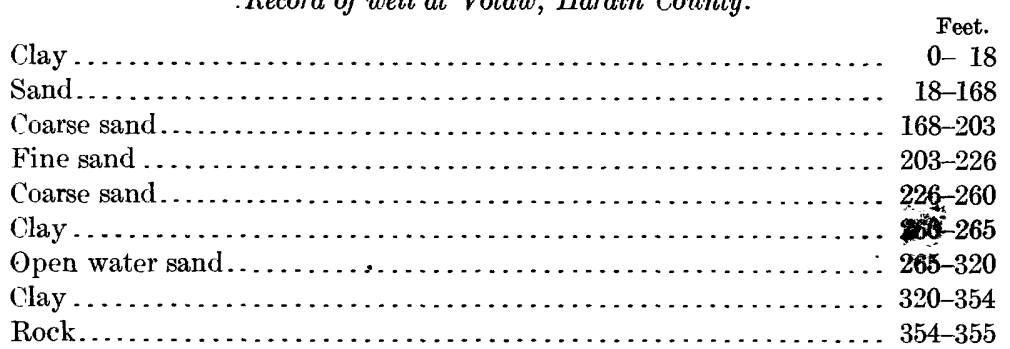

Analysis of water from deep well at Votaw, Hardin County,a

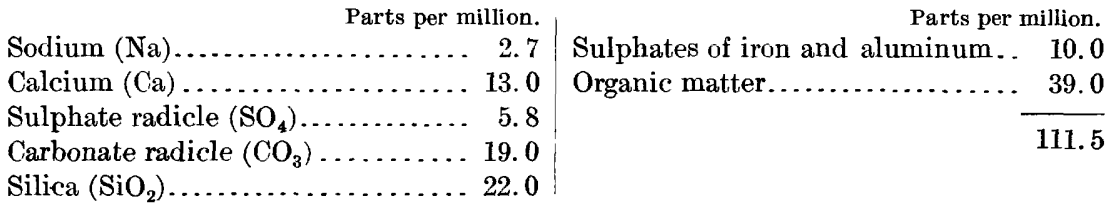

\section{TYLER COUNTY.}

Shallow wells.-In the southern part of Tyler County the wells are about 20 feet deep, in the eastern part about 25 feet, in the northern part about 80 feet, and in the western part about 65 feet.

Artesian wells.-No attempts to obtain artesian water have been made in this county, but an oil well was drilled near Woodville to a depth of 933 feet without finding artesian water.

\section{JASPER COUNTY.}

Shallow wells.--Shallow wells in Jasper County vary in depth from 20 to 50 feet.

Artesian wells. - So far only three artesian wells have been reported from this county, and these are all located on the ranch of:Wiess \& Sanders, near Wiess Bluff, in the southern part of the county. Various data concerning these wells are given below. There is a deep well at Kirbyville, a record of which follows, also an analysis of its water.

Artesian wells in Jasper County.

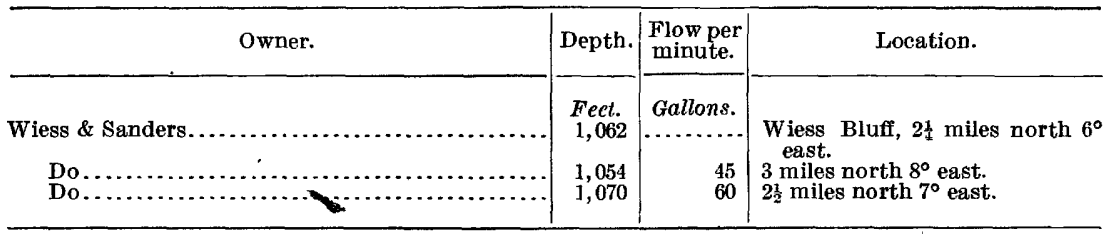

a Expressed by analyst in grains per gallon and hypothetical combinations; recomputed to parts per million and ionic form at U. S. Geological Survey. 
Record of Wiess \& Sanders artesian well No. 1, Jasper County.a

Fine sandy loam

Feet.

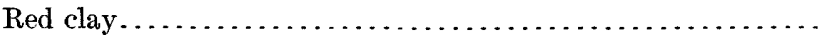

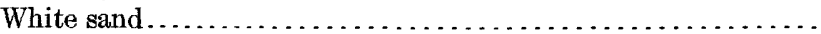

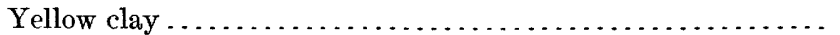

$25-\quad 75$

Fine blue sand .......................................

$75-\quad 96$

Yellow clay ................................... $129-156$

White sand ....................................... 156- 173

Yellow clay .................................. 173- 225

Fine blue sand .................................. $225-252$

Hard yellow clay . . . . . . . . . . . . . . . . . . . . . . . . . . . $2582-386$

White sand ..................................... $386-476$

Blue clay ...................................... 476- 547

Blue sand ...................................... $547-569$

Hard blue clay .................................. $\quad 569-579$

Coarse white sand............................... $579-628$

Blue clay ....................................... $628-646$

Fine blue clay................................. $646-676$

Hard blue clay ................................. 676 695

Coarse white sand ............................... $695-\quad 750$

Hard blue clay .................................. $\quad 750-759$

Soft blue clay..................................... $759-784$

White sand ....................................... $784-794$

Hard blue clay ................................. $794-814$

Fragmentary sand................................ $814-818$

Hard blue clay ................................ $818-900$

Rotten sandstone ................................ 900 906

Blue clay ....................................... $906-913$

White sand $\ldots \ldots \ldots \ldots \ldots \ldots \ldots \ldots \ldots \ldots \ldots \ldots \ldots \ldots \ldots \ldots, 913-935$

Hard blue clay ............................... 935-1,002

Coarse white sand ............................. 1, 002-1,021

Fine gravel................................. 1,021-1, 038

Coarse gravel ............................... 1, 038-1,052

White sand.................................... 1,052-1, 086

Blue clay........................................ 1, 086-1, 104

White sand ................................... 1, 104-1, 202

Record of Wiess \& Sanders artesian well No. 2, Jasper County.

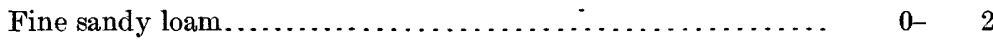

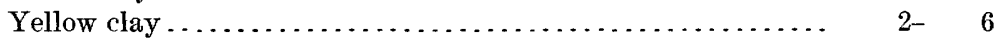

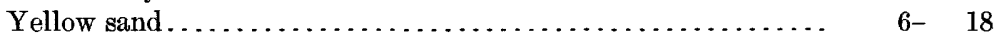

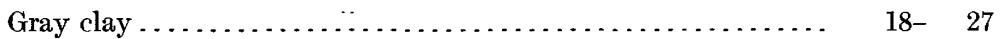

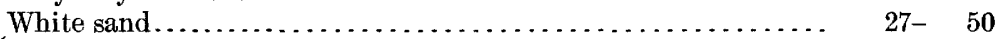

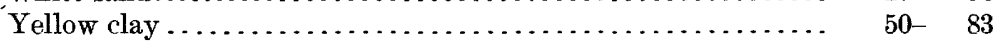

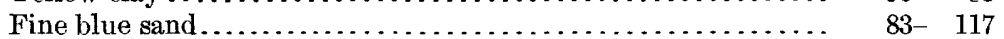

Blue clay ....................................... $117-152$

White sand ...................................... 152 173

Blue clay ....................................... 173- 234

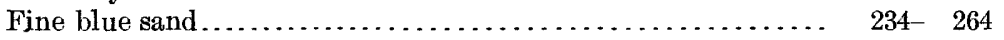

Blue clay..................................... 264 295

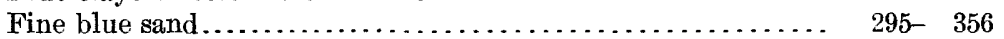

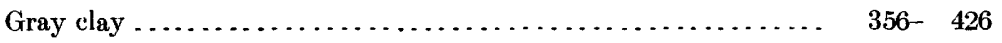

a Capacity of this well is 165 gallons a minute, or 237,000 gallons every twenty-four hours. 


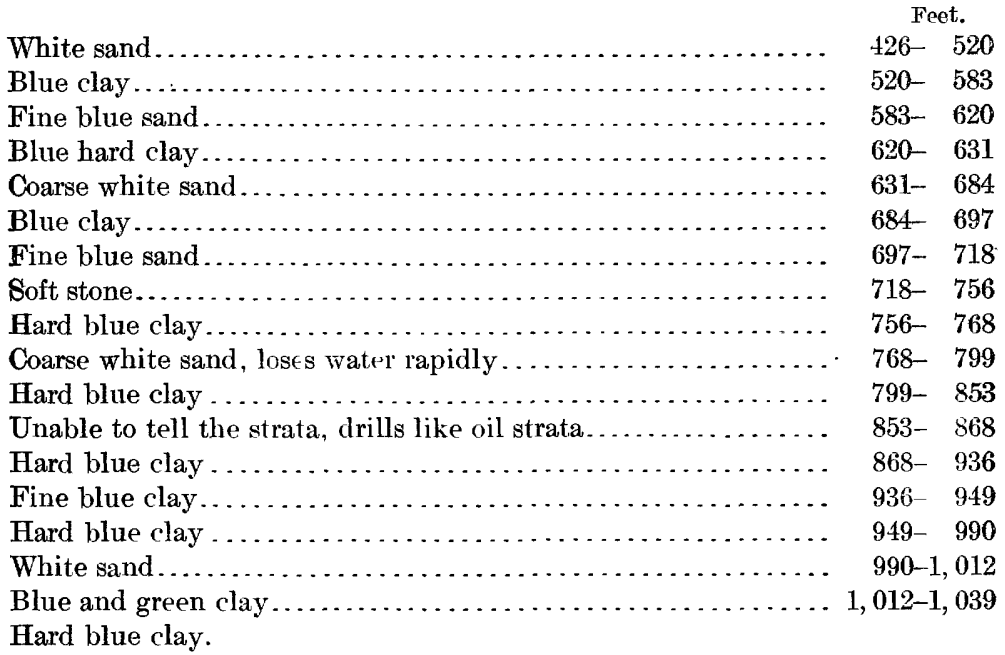

Record of deep well at. Kirbyville, Jasper County.

Yellow clay .................................... $0-17$

Yellow sand ................................... 17-34

Coarse white sand .................................. 34-54

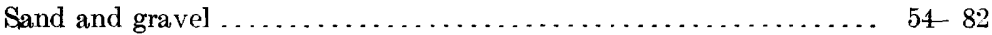

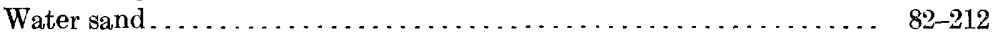

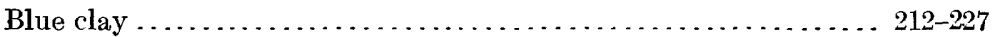

Analysis of water from deep well at Kirbyrille, Jasper County.a

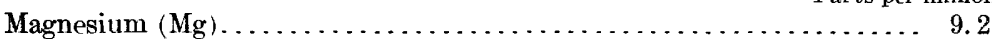

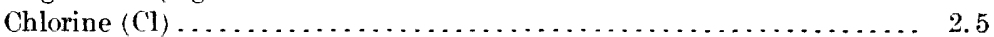

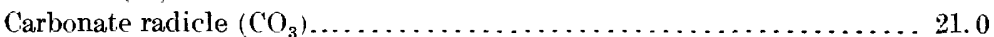

Sulphates of iron and aluminum........................... 15.0

47.7

\section{NEWTON COUNTY.}

Shallow wells.-The average depth of wells in Newton County is 35 feet, the deepest one being in the northern part.

Artesian wells.-The only artesian well in this county is located near Call and is owned by the Kirby Lumber Company. This well is 796 feet deep, 4 inches in diameter, and has a flow of 38 gallons a minute. Several oil wells have been drilled near this place, but no artesian flows have been obtained.

\section{WEBB COUN'TY.}

Shallow wells.-The shallow wells of Webb County vary considerably in depth. In the western part they have an average depth of 60 feet; in the northern part, 425 feet; and in the eastern part, 375 feet. It is very difficult to obtain water in the southern part of the county.

a Expressed by analyst in grains per gallon and hypothetical combinations; recomputed to parts per million and ionic form at U.S. Geological Survey. 
Artesian wells.-At Bruniville, a station on the Texas Mexican Railway, four artesian wells were drilled for A. M. Bruni. They are each 325 feet deep and flow only about 3 gallons a minute. They are located on 1 acre of land, just south of Bruniville, within 100 feet of the railroad track.

\section{MAVERICK COUN'TY.}

Shallow wells.-It is difficult to find water in Maverick County. In the northern part one well was drilled to a depth of 918 feet without getting water, while wells in other localities 500 feet deep yielded salty water.

Artesian wells.-So far as can be ascertained there are no artesian wells in Maverick County.

\section{DIMMIT COUNTY.}

Shallow wells.-In the Nueces Valley good wells are obtained at moderate depths, but on the higher lands they vary from 100 to 150 feet in depth.

Artesian wells.-There are over 60 artesian wells in Dimmit County, ranging in depth from 300 to 700 feet. The water is used for both stock and irrigation purposes. The following is a list of the artesian wells of this county, with depth, flow, and other data concerning them:

Artesian wells in Dimmit County.

\begin{tabular}{|c|c|c|c|c|}
\hline Owner. & Depth. & Flow. & $\begin{array}{l}\text { Diame } \\
\text { ter. }\end{array}$ & $\begin{array}{c}\text { Distance and direction from } \\
\text { Carrizo Springs. }\end{array}$ \\
\hline 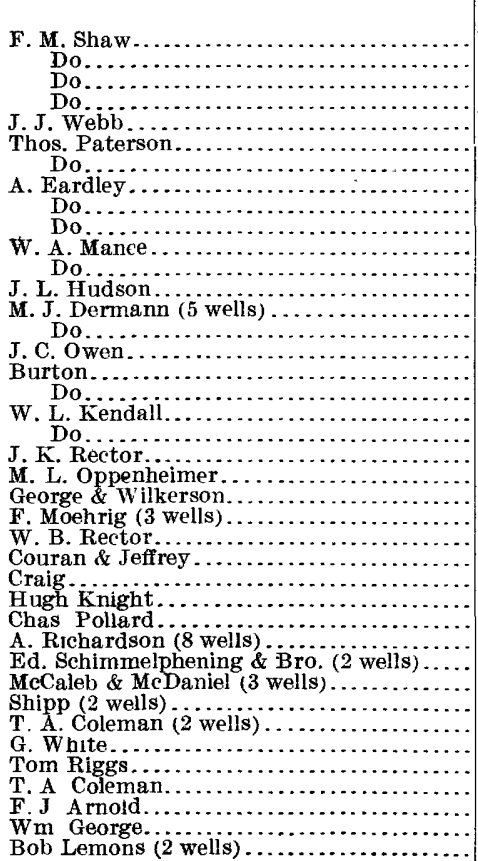 & $\begin{array}{r}350-400 \\
500 \\
600 \\
650 \\
\\
590-690 \\
600 \\
600 \\
500 \\
350 \\
400 \\
350 \\
315 \\
375 \\
350 \\
350 \\
600 \\
350 \\
600 \\
350-600 \\
382 \\
350 \\
325 \\
600 \\
600 \\
600-650 \\
600 \\
400 \\
325,418 \\
300 \\
350 \\
350 \\
350 \\
500 \\
350 \\
350,700\end{array}$ & $\begin{array}{r}\text { Gallons. } \\
150 \\
150 \\
\text { weak. } \\
\text { Weak. } \\
150 \\
200 \\
200 \\
1,400 \\
1,400 \\
1,400 \\
100 \\
\text { No flow. } \\
150 \\
125 \\
150 \\
150 \\
125 \\
125 \\
150 \\
\text { Weak. } \\
200 \\
125 \\
100 \\
a 150 \\
200 \\
100 \\
50 \\
350 \\
350 \\
100-600 \\
150,200 \\
125-150 \\
100 \\
50,75 \\
125 \\
125 \\
125 \\
150 \\
20 \\
\text { No flow. }\end{array}$ & 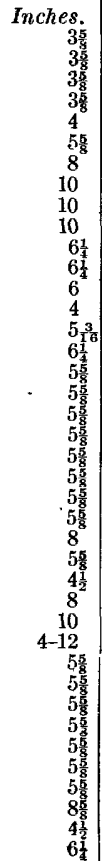 & $\begin{array}{l}2 \frac{1}{2} \text { miles north. } \\
\text { Do. } \\
5 \text { miles northwest. } \\
5 \text { miles east. } \\
\text { Do. } \\
4 \text { miles east. } \\
\text { Do. } \\
5 \frac{1}{2} \text { miles east. } \\
\text { Do. } \\
\text { Do. } \\
4 \text { miles east. } \\
\text { Do. } \\
2 \text { miles northeast. } \\
3 \text { miles north. } \\
\text { Do. } \\
21 \text { miles north. } \\
2 \text { miles north. } \\
\text { Do. } \\
3 \text { miles north. } \\
\text { Do. } \\
5 \text { miles east. } \\
1 \text { mile northeast. } \\
1 \text { mile north. } \\
21 \frac{1}{2} \text { miles north. } \\
\text { Do. } \\
\text { Do. } \\
\frac{1}{2} \text { mile east. } \\
5 \text { miles southeast. } \\
\text { Do. } \\
6 \text {-10 miles southeast. } \\
6 \text { miles southeast. } \\
5 \text { miles southeast. } \\
4 \frac{1}{2} \text { miles southeast. } \\
5 \text { miles south. } \\
10 \text { miles northwest. } \\
\text { Do. } \\
\text { Do } \\
5 \text { miles southeast. } \\
5 \frac{1}{2} \text { miles southeast. } \\
6 \text { miles south west. }\end{array}$ \\
\hline
\end{tabular}

a Each. 
Record of Eardley Barosa Creek well, Dimmit County (near Carrizo Sprngs).

Light red soil and clay $\ldots \ldots \ldots \ldots \ldots \ldots \ldots \ldots \ldots \ldots \ldots \ldots \ldots, 0,3$

Pale blue clay ............................ 9

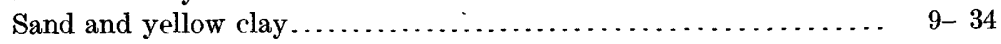

Yellow clay .................................. $34-64$

Pale to dark-blue clay.............................. $64-99$

Sandstone, a little salt water, no flow .................. 99-102

Sticky pale-blue clay................................ 102-152

Blue clay containing small seams of coal . . . . . . . . . . . . . 152-252

Sand and clay ................................... 252-297

Fine-grained sandstone............................. 297-312

Sand and clay..................................... $312-332$

Blue clay ..................................... $332-377$

Darker blue clay................................ $377-417$

Sand and clay .................................. 417-462

Fine sand rock. Small flow....................... 462-522

Sandstone; flow gradually increased ...................... 522-682

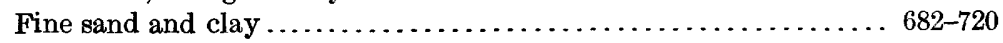

\section{ZAVALLA COUNTY.}

Shallow wells.-Water from shallow wells is obtained in the western part of Zavalla County at an average depth of 50 feet, in the southern part at a depth of 75 feet, and in the eastern and northern parts at a depth of 100 feet.

Artesian wells.-Artesian wells have been drilled in the western and southwestern parts of the county along some of the tributaries of Nueces River. The following list of wells and data concerning them were furnished by George C. Hermann, of Batesville.

Artesian wells in Zavalla County.

\begin{tabular}{|c|c|c|c|c|}
\hline Owner. & Depth. & Flow. & $\begin{array}{l}\text { Diam- } \\
\text { eter. }\end{array}$ & $\begin{array}{c}\text { Distance and direction from } \\
\text { Batesville. }\end{array}$ \\
\hline 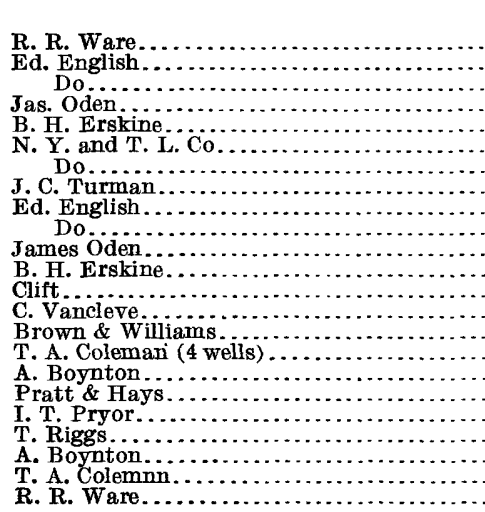 & \begin{tabular}{|r} 
Feet. \\
211 \\
450 \\
450 \\
400 \\
250 \\
400 \\
450 \\
450 \\
390 \\
410 \\
500 \\
420 \\
450 \\
310 \\
560 \\
$450-460$ \\
460 \\
900 \\
1,029 \\
420 \\
460 \\
460 \\
260
\end{tabular} & $\begin{array}{l}\text { Slight. } \\
\text { Strong. } \\
\text { Strong. } \\
\text { Strong. } \\
\text { Strong. } \\
\text { Strong. } \\
\text { Strong. } \\
\text { Strong. } \\
\text { Strong. } \\
\text { Strong. } \\
\text { Slight. } \\
\text { (a) } \\
\text { Flows. } \\
\text { Flows. } \\
\text { Sttrong. } \\
\text { Strong. }\end{array}$ & $\begin{array}{r}\text { Inches. } \\
5 \\
5 \\
5 \\
5 \\
5 \\
5 \\
5 \\
5 \\
6 \\
6 \\
6 \\
6 \\
6 \\
6 \\
6 \\
6 \\
6 \\
6 \\
10 \\
10 \\
6 \\
6 \\
6 \\
6 \\
6\end{array}$ & $\begin{array}{l}31 \text { miles south } 56^{\circ} \text { west. } \\
288^{1} \text { miles south } 46^{\circ} \text { west. } \\
28 \frac{1}{2} \text { miles south } 46^{\circ} \text { west. } \\
29 \text { miles south } 49^{\circ} \text { west. } \\
30 \text { miles south } 50^{\circ} \text { west. } \\
25 \text { miles south } 58^{\circ} \text { west. } \\
25 \text { miles south } 66^{\circ} \text { west. } \\
28 \text { miles south } 71^{\circ} \text { west. } \\
28 \text { miles south } 47^{\circ} \text { west. } \\
28 \text { miles south } 46^{\circ} \text { west. } \\
28 \frac{1}{2} \text { miles south } 48^{\circ} \text { west. } \\
30 \text { miles south } 50^{\circ} \text { west. } \\
277^{\frac{1}{2}} \text { miles south } 47^{\circ} \text { west. } \\
28 \text { miles south } 53^{\circ} \text { west. } \\
26 \text { miles south } 51^{\circ} \text { west. } \\
31 \text { miles south } 49^{\circ} \text { west. } \\
29 \text { miles south } 46^{\circ} \text { west. } \\
25 \text { miles south } 40^{\circ} \text { west. } \\
16 \text { miles south } 70^{\circ} \text { west. } \\
28 \text { miles south } 45^{\circ} \text { west. } \\
29 \text { miles south } 46^{\circ} \text { west. } \\
31 \text { miles south } 49^{\circ} \text { west. } \\
32 \text { miles south } 56^{\circ} \text { west. }\end{array}$ \\
\hline
\end{tabular}

a Water rises within 10 feet of surface. 


\section{LASALLE COUNTY.}

Shallow wells.-In Lasalle County the pump wells are considerably deeper than those in adjoining localities. They vary from 150 to 200 feet in depth.

Artesian wells.-There are 27 artesian wells in this county. The area of greatest development in well boring is around Artesia, where a number of wells are utilized for irrigation purposes. They vary in depth from 200 to 500 feet and usually furnish a strong flow of good water. At Cotulla the International and Great Northern Railroad has drilled a well 1,008 feet deep, but the water is slightly impregnated with salts of magnesia. In the vicinity of Dull's ranch, in the northeastern portion of the county, along Frio River, there is a well-developed artesian district. The following is a list of the artesian wells of the county:

Artesian wells in Lasalle County.

\begin{tabular}{|c|c|c|c|c|}
\hline Owner. & Depth. & $\begin{array}{c}\text { Flow per } \\
\text { minute. }\end{array}$ & $\begin{array}{l}\text { Diam- } \\
\text { eter. }\end{array}$ & Location. \\
\hline & Feet. & Gallons. & Meters. & \\
\hline $\begin{array}{l}\text { International and Great Northern R. R. } \\
\text { Do }\end{array}$ & $\begin{array}{r}900 \\
1,008\end{array}$ & & & Cotulla. \\
\hline J. W. McInnis... & $\begin{array}{r}1,000 \\
486\end{array}$ & 15 & & Do. \\
\hline Joe Cotulla.... & 400 & 4 & & Cotulla, $1 \frac{1}{2}$ miles north. \\
\hline A. Armstrong... & 764 & 2 & & Cotulla, 8 miles west. \\
\hline $\begin{array}{r}\text { J. M. Ramsey ... } \\
\text { Do . . }\end{array}$ & 550 & 24 & $\begin{array}{l}6 \\
6\end{array}$ & Artesia, 2 miles northeast. \\
\hline Do........ & $\begin{array}{l}030 \\
350\end{array}$ & $\begin{array}{l}24 \\
15\end{array}$ & 6 & $\begin{array}{l}\text { Yo. } \\
\text { Do. }\end{array}$ \\
\hline Do.. & 350 & 8 & 6 & Artesia, 1 mile northeast. \\
\hline Do....... & 186 & 5 & 6 & Artesia, $\frac{1}{2}$ mite northeast. \\
\hline J. W. Bucow.......... & 400 & 20 & 6 & Artesia, 4 miles east. \\
\hline W. H. McWhorter & 450 & 10 & 6 & Artesia, 1 mile south. \\
\hline 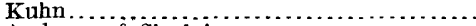 & 600 & 10 & 6 & Artesia, 6 miles east. - \\
\hline Anderson \& Sinclair. & 670 & 10 & 8 & Artesia, 1 mile northwest. \\
\hline Do............ & 670 & 10 & 8 & Artesia, $\frac{1}{2}$ mile northeast. \\
\hline Crossley ....... & 400 & 10 & 6 & Artesia, 1 mile southeast. \\
\hline C. H. DeRyle... & 450 & 10 & 6 & Artesia, $1 \frac{1}{2}$ mile southeast. \\
\hline T. J. Alderman. & 180 & 0 & & Artesia, 3 miles northeast. \\
\hline Do............ & 650 & 0 & & Do. \\
\hline Naylor \& Jones. & 295 & 4 & 6 & Dull's ranch, 2 miles east. \\
\hline Do............. & $\begin{array}{l}366 \\
720\end{array}$ & $\begin{array}{r}4 \\
30\end{array}$ & $\begin{array}{l}6 \\
6\end{array}$ & $\begin{array}{l}\text { Dull's ranch, } 7 \text { miles east. } \\
\text { Dull's ranch, } 14 \text { miles north- }\end{array}$ \\
\hline Do. & 310 & 12 & 6 & Dull's ranch, 3 miles east. \\
\hline & 300 & & 6 & Dull's ranch, 7 miles north- \\
\hline W. C. Irwin. & 797 & 100 & & Dull's ranch, 7 miles north- \\
\hline Uhl \& Gaith $\ldots \ldots \ldots \ldots$ & 767 & 4 & 1 & Cotulla, northwest. \\
\hline International and Great i & 800 & 0 & & Encinal. \\
\hline
\end{tabular}

\section{MCMULLEN COUNTY.}

Shallow wells.-The nonflowing wells of McMullen County are generally deep. In the eastern part they have an average depth of 130 feet, in the northern part 250 feet, and in the southern part 350 feet. No information has been received concerning the depth of wells in the western part of the county. 
Artesian wells.-Data have been obtained of seven artesian wells in McMullen County. A list of these wells, with their depth, flow, size, and approximate location is given below:

Artesian wells in Mc Mullen County.

\begin{tabular}{|c|c|c|c|c|}
\hline Owner. & Depth. & $\begin{array}{l}\text { Flow per } \\
\text { minute. }\end{array}$ & $\begin{array}{l}\text { Diame- } \\
\text { ter. }\end{array}$ & Location. \\
\hline 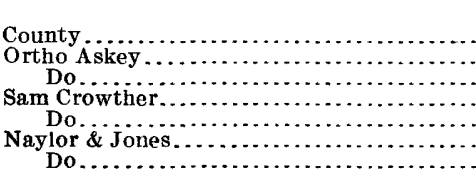 & $\begin{array}{r}\text { Feet. } \\
485 \\
300 \\
147 \\
1,728 \\
1,325 \\
700 \\
512\end{array}$ & $\begin{array}{r}\text { Gallons. } \\
5 \\
250 \\
200 \\
15 \\
15\end{array}$ & 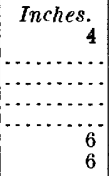 & $\begin{array}{l}\text { Public square, Tilden. } \\
\text { Tilden, } 12 \text { miles east. } \\
\text { Tilden, } 13 \text { miles east. } \\
\text { Tilden, } 14 \text { miles northeast. } \\
\text { Do. } \\
\text { Tilden, } 20 \text { miles west. } \\
\text { Do. }\end{array}$ \\
\hline
\end{tabular}

FRIO COUNTY.

Shallow wells.-Water is obtained from shallow wells in Frio County at depths of 60 to 125 feet.

Artesian wells.-There are flowing wells along San Miguel Creek, also at Derby, and northwest of Derby along Frio River. A typical artesian well of Frio County is shown on Pl. I, $B$ (p. 1). Many of the wells along San Miguel Creek are located along the creek bed, on very low ground; most of them are about 400 feet in depth, 8 inches in diameter, and flow about 10 gallons a minute. The general distribution of these wells is shown in Pl. II (p. 2), and their depth, size, flow, and approximate location are given in the following table:

Artesian wells in Frio County.

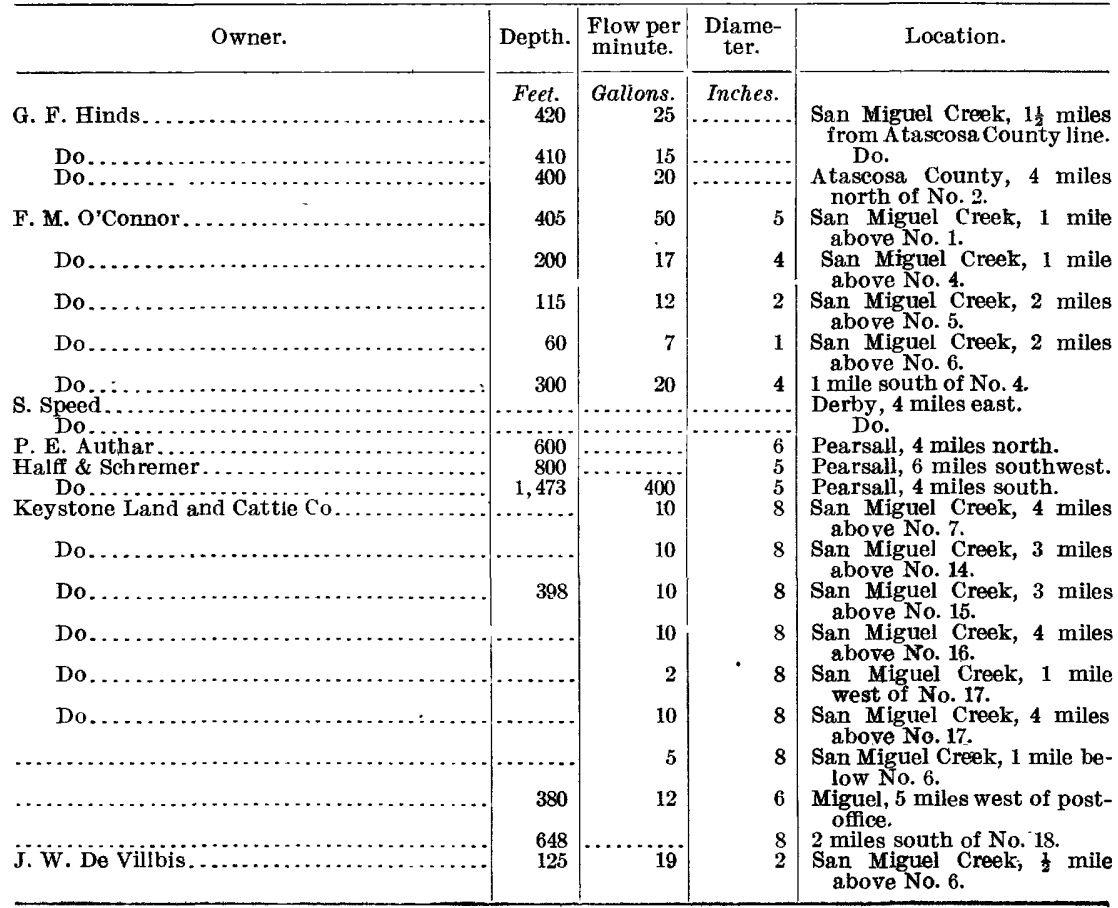




\section{ATASCOSA COUNTY.}

Shallow wells.-A good supply of excellent water is obtained from wells 40 to 60 feet deep throughout the greater part of Atascosa County.

Artesian wells.-Artesian water is found in all parts of this county, at depths varying from 200 to 700 feet. The county is well drained by the tributaries of San Miguel Creek, and wells for the most part are located along these tributaries. The approximate location of artesian wells, also their depth, flow, and diameter are given in the following table:

Artesian wells in Atascosa County.

\begin{tabular}{|c|c|c|c|c|c|}
\hline Owner. & Depth. & $\begin{array}{l}\text { Flow per } \\
\text { minute. }\end{array}$ & $\begin{array}{l}\text { Diarne- } \\
\text { ter. }\end{array}$ & $\begin{array}{c}\text { Distance and cirection } \\
\text { Pleasanton. }\end{array}$ & f:on \\
\hline 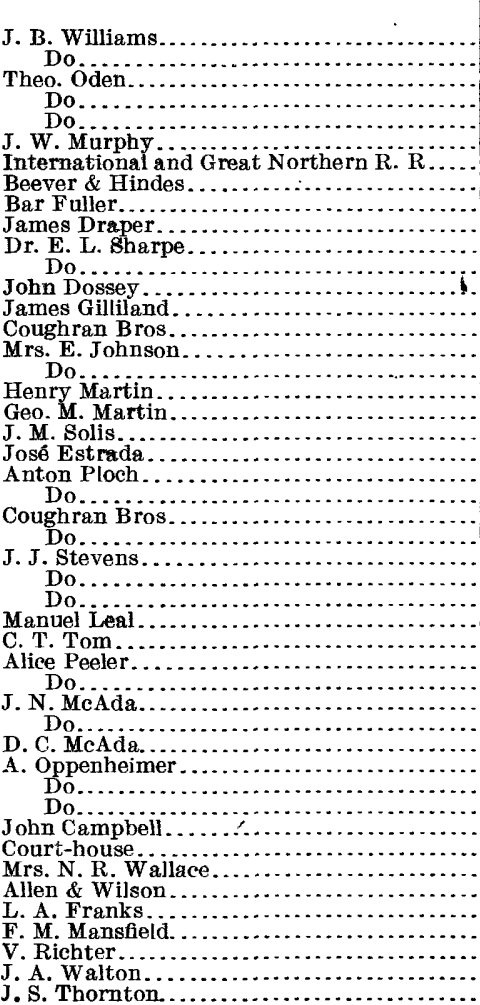 & $\begin{array}{r}\text { Feet. } \\
120 \\
520 \\
447 \\
376 \\
620 \\
625 \\
740 \\
400 \\
314 \\
230 \\
500 \\
340 \\
320 \\
510 \\
397 \\
337 \\
227 \\
430 \\
319 \\
300 \\
240 \\
228 \\
208 \\
308 \\
540 \\
915 \\
700 \\
1,011 \\
207 \\
441 \\
139 \\
165 \\
340 \\
202 \\
200 \\
729 \\
700 \\
525 \\
280 \\
378 \\
377 \\
357 \\
368 \\
406 \\
301 \\
497 \\
700\end{array}$ & 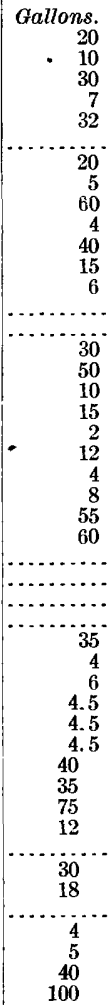 & $\begin{array}{r} \\
\cdots \\
\ldots \ldots \ldots\end{array}$ & $\begin{array}{l}1 \text { mile east. } \\
\text { Do. } \\
8 \text { miles south. } \\
\text { Do. } \\
\text { Do. } \\
11 \text { miles southwest. } \\
20 \text { miles southwest. } \\
19 \text { miles southwest. } \\
4 \text { niles northeast. } \\
4 \text { miles north. } \\
\text { In town. } \\
\text { Do. } \\
7 \text { miles southeast. } \\
6 \text { miles northeast. } \\
5 \text { miles east. } \\
\text { Do. } \\
3 \text { miles east. } \\
4 \text { miles southeast. } \\
3 \text { miles north west. } \\
6 \text { miles northwest. } \\
5 \text { miles northwest. } \\
4 \text { miles northeast. } \\
\text { Do. } \\
6 \text { miles northeast. } \\
5 \text { miles east. } \\
8 \text { miles northeast. } \\
12 \text { miles northeast. } \\
11 \text { miles east. } \\
8 \text { miles southeast. } \\
19 \text { miles southeast. } \\
16 \text { miles southeast. } \\
\text { Do. } \\
12 \text { miles southeast. } \\
13 \text { miles southeast. } \\
12 \text { miles southeast. } \\
6 \text { miles south. } \\
4 \text { miles south. } \\
14 \text { miles south. } \\
18 \text { miles southeast. } \\
\text { In town. } \\
\text { Do. } \\
\text { Do. } \\
\text { Do. } \\
\text { Do. } \\
2 \frac{1}{2} \text { miles northeast. } \\
\text { In town. } \\
\text { Do. }\end{array}$ & - \\
\hline
\end{tabular}

\section{BEXAR COUNTY.}

Shallow wells. - In the southern part of Bexar County water can be procured at depths varying from 30 to 60 feet; near Vanraub, at a depth of 325 feet, and at Leon Springs, at depths of 40 to 200 feet.

Artesian wells.-There arenearly 100 artesian wells in Bexar County. Some of them are among the strongest wells in the State. The water 
is of excellent quality and is used largely for irrigation. The following is a list of the artesian wells, giving location and other data:

Artesian wells in Bexar County.

\begin{tabular}{|c|c|c|c|}
\hline Owner. & Depth. & $\begin{array}{l}\text { Flow per } \\
\text { minute. }\end{array}$ & $\begin{array}{l}\text { Location with respect to } \\
\text { San Antonio. }\end{array}$ \\
\hline West End Town Co. . . . . . . . . . . . . . . . . . . . . . & Feet. & $\begin{array}{r}\text { Gallons. } \\
150\end{array}$ & West End Lake. \\
\hline Russ & 250 & 60 & In town. \\
\hline Brendle & 583 & & 3 miles north. \\
\hline Yantis... & 540 & 400 & 2.5 niles northwest. \\
\hline Waterworks No. $1 . . . \ldots$. . & 630 & 1,042 & $\frac{1}{2}$ mile below head of river. \\
\hline 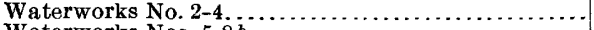 & 780 & $a 1,042$ & $1 \frac{1}{2}$ miles below head of river. \\
\hline 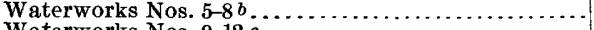 & 880 & a 4,166 & Market street. \\
\hline 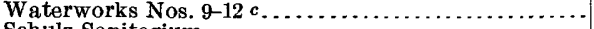 & 880 & $a 1,740$ & Do. \\
\hline 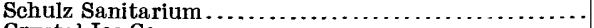 & 712 & 555 & Alamo Plaza. \\
\hline 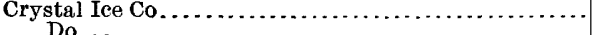 & 657 & 417 & Eighth street. \\
\hline 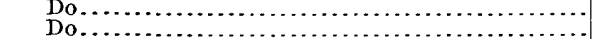 & 657 & $\begin{array}{l}417 \\
978\end{array}$ & Do. \\
\hline (n) & 850 & $\begin{array}{r}278 \\
36\end{array}$ & $\begin{array}{l}\text { Do. } \\
\text { Do. }\end{array}$ \\
\hline Street railway. & 980 & 156 & Tenth street. \\
\hline 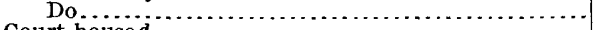 & 1,140 & 17 & Do. \\
\hline 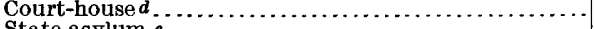 & 760 & 861 & Center of eity. \\
\hline 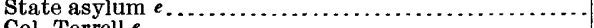 & 1,900 & Flows. & 3 miles southeast. \\
\hline 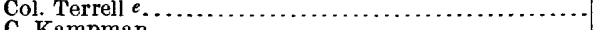 & 1,900 & 555 & 5 miles southeast. \\
\hline $\begin{array}{r}\text { C. } \\
\text { Dompman }\end{array}$ & $\begin{array}{l}650 \\
464\end{array}$ & $\begin{array}{r}200 \\
20\end{array}$ & $\begin{array}{l}3 \text { miles east. } \\
\text { Do. }\end{array}$ \\
\hline Geo. Dulnig $f$ & 2,215 & 1,007 & 6 miles southeast. \\
\hline Santa Rosa Hospital.... & 1,000 & 104 & $\begin{array}{l}400 \text { yards northwest court- } \\
\text { house. }\end{array}$ \\
\hline Do. & 1,250 & & Do. \\
\hline 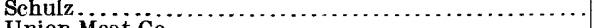 & 822 & 200 & $2 \frac{1}{2}$ miles northwest. \\
\hline (n, & 1,202 & 300 & $1 \frac{1}{2}$ miles south west. \\
\hline 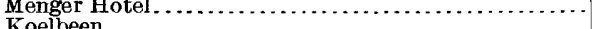 & 1,160 & 170 & \\
\hline 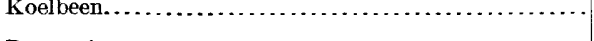 & 1,100 & 140 & $\begin{array}{l}\text { Southern Pacific round- } \\
\text { house. }\end{array}$ \\
\hline Dignowitty. & 465 & 55 & $1 \frac{1}{2}$ miles west. \\
\hline Kampman. & 850 & 200 & Velita street. \\
\hline Epps...... & 884 & 70 & $2 \frac{1}{4}$ miles southwest. \\
\hline 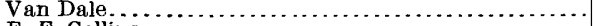 & 835 & 55 & 2 miles west. \\
\hline F. F. Collins.... & 700 & 1,200 & $\frac{1}{2}$ mile southwest. \\
\hline (n. & $\begin{array}{r}850 \\
500\end{array}$ & 300 & mile northeast. \\
\hline (n. & $\begin{array}{r}1,500 \\
900\end{array}$ & $\begin{array}{l}400 \\
200\end{array}$ & $\begin{array}{l}2 \frac{1}{2} \text { miles southwest. } \\
\text { Do. }\end{array}$ \\
\hline Barnes. . & 950 & 1,200 & Do. \\
\hline Meerscheidt-Stieren Irrigation Co.g ...... & 950 & 800 & 3 miles west. \\
\hline A. Herff $\ldots \ldots \ldots \ldots \ldots \ldots \ldots \ldots \ldots \ldots \ldots \ldots \ldots \ldots \ldots \ldots$ & 1,200 & Slight. & $3 \frac{1}{2}$ miles west. \\
\hline$\ldots \ldots \ldots . . .6$. & 750 & 377 & 3 miles west. \\
\hline$\ldots \ldots \ldots \ldots \ldots \ldots \ldots$ & & & 5 miles southwest. \\
\hline 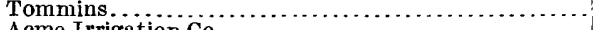 & 1,500 & Slight. & $2 \frac{1}{2}$ miles south. \\
\hline 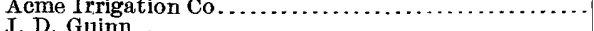 & 1,200 & No tlow. & 5 miles southwest. \\
\hline 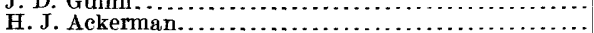 & 1,400 & $\begin{array}{l}50 \\
50\end{array}$ & $\begin{array}{l}3 \text { miles northeast. } \\
6 \text { miles east. }\end{array}$ \\
\hline Watters................. & 1,400 & 50 & $\begin{array}{l}\text { 6 miles east. } \\
2 \frac{1}{2} \text { miles southwest. }\end{array}$ \\
\hline .............. & 800 & No flow. & 3 miles northwest. \\
\hline J. C. Chaney.... & 1,500 & 100 & $2 \frac{1}{2}$ miles southeast. \\
\hline City brewery........... & 728 & 2,083 & James street. \\
\hline 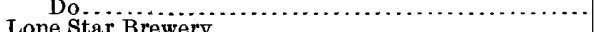 & 728 & 2,083 & Do. \\
\hline 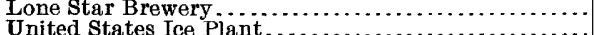 & 805 & 650 & Jones street. \\
\hline $\begin{array}{l}\text { United States Ice Plant } \ldots \ldots \\
\text { Do } \ldots \ldots \ldots\end{array}$ & 710 & 650 & Grayson street. \\
\hline 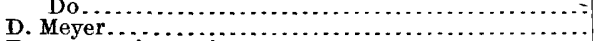 & 710 & 650 & Do. \\
\hline $\begin{array}{l}\text { D. Meyer .................. } \\
\text { Tappans polo ranch... }\end{array}$ & ........ & 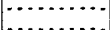 & 3 miles west. \\
\hline $\begin{array}{l}\text { Tappans pol } \\
\text { J. D. Guinn. }\end{array}$ & 1,000 & Noflow. & 5 miles northwest. \\
\hline T. B. Da & 635 & Slight. & $5 \frac{1}{2}$ miles northeast. \\
\hline W. Eisen & 700 & & $\begin{array}{l}7 \text { miles northeast. } \\
5 \text { miles east. }\end{array}$ \\
\hline Urbahn ......... & 1,200 & No flow. & 4 miles east. \\
\hline Kampman $h \ldots$ & 1,000 & $\begin{array}{l}\text { Occa- } \\
\text { sional. }\end{array}$ & 3 miles north. \\
\hline St. Louis College & 720 & No flow. & 5 miles west. \\
\hline Do. & 720 & ....do... & Do. \\
\hline International and Great North & 808 & Good. & At Davenport. \\
\hline
\end{tabular}

a Each.

b Four 12-inch wells.

c Four 8-inch wells.

$d$ Gas and water at 460 and 620 feet below surface.

$e$ Hot sulphur water.

$f$ 6-inch well yielding hot sulphur water.

$g$ Two wells: One 6-inch, with 800-gallon flow; one 10-inch, wlth 3,000-gallon flow..

$h$ Water at 630 feet.

W Water rises within 110 feet of surface. 


\section{WILSON COUNTY.}

Shallow wells.-The shallow wells of Wilson County are from 30 to 150 feet deep.

Artesian wells.-There are two principal artesian-well districts in the county-one in the southwestern part, where a group of wells is owned by J. S. Thornton and J. J. Stevens, and one, in the vicinity of Stockdale and Sutherland Springs. A list of these wells, including available data, is given below.

Artesian vells in Wilson County.

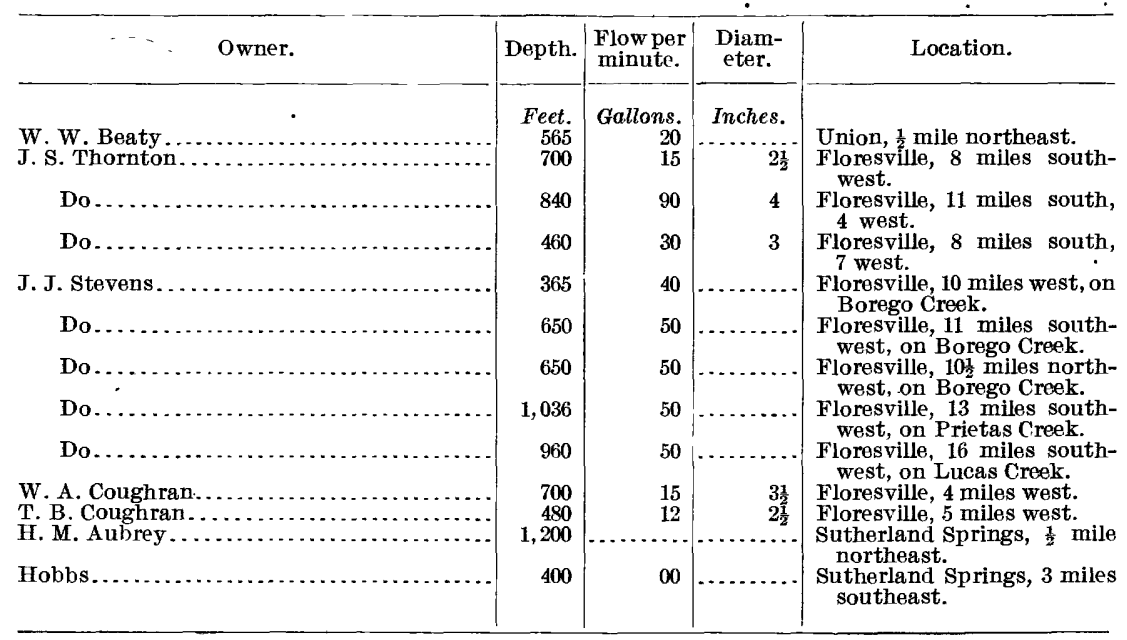

\section{GUADALUPE COUNTY.}

Shallow wells.-Water is obtained in Guadalupe County in the eastern part at an average depth of 40 feet, in the southern part at 60 feet, in the western part at 70 feet, and in the northern part at 80 feet.

Artesian wells.-The only attempt to develop the artesian-water resources of this county was made by Adolph Ziegenhols, on his farm 12 miles north of Seguin, where a flow of strong sulphur water was found at a depth of 800 feet.

\section{CALDWELL COUNTY.}

Shallow wells.-Good wells are obtained throughout the greater part of Caldwell County at depths varying from 18 to 50 feet. Near Lockhart wells are from 18 to 20 feet deep, but on the prairie west of Lockhart they are somewhat deeper. South of Maxwell and east of Martindale it is difficult to get water, and it is generally not obtained at depths less than 100 feet. 
Artesian wells.-Only two artesian wells have been reported from this county. T. F. Hudson, near Lockhart, has a 6 -inch flowing well 260 feet deep, and V. Leshikar has one 5 miles west of Lockhart which has a depth of 180 feet, a diameter of 8 inches, and a flow of only a few gallons a minute.

\section{BASTROP COUNTY.}

Shallow wells.-Throughout Bastrop County the shallow wells are from 35 to 70 feet deep and generally furnish a good supply of water.

Artesian wells.-Very little prospecting has been done for artesian water in this county. In 1893 a well was drilled to a depth of 1,010 feet near Bastrop by the Bastrop Building and Loan Association without striking water.

\section{LEE COUNTY.}

Shallow wells.-In Lee County the average shallow well is 40 to 50 feet deep, and a good supply is usually obtained.

Artesian wells.-Owing to the ease with which shallow wells may be obtained in this county, few attempts have been made to develop artesian water. The only flowing well in the county is owned by M. G. York, near Leobau. It is a 6 -inch well, 800 feet deep, but the exact flow has not been ascertained.

\section{ROBERTSON COUNTY.}

Shallow wells.-A good supply of water is found in Robertson County about 40 feet below the surface.

Artesian wells.-There are a large number of flowing wells between Big and Little Brazos rivers, from a point opposite Calvert to the mouth of the Little Brazos, a distance of about 25 miles. Water is obtained throughout this valley at four artesian horizons at depths of $160,450,650$, and 920 feet. Attempts to get water east of Hearne, on the highland extending from Bremond to Franklin, have resulted in failure. At Hearne there are 23 flowing wells, nearly all of which obtain water from an artesian horizon 700 feet below the surface. The following is a list: 
Artesian wells at Hearne.

\begin{tabular}{|c|c|c|c|}
\hline Owner. & Depth. & Owner. & Depth. \\
\hline 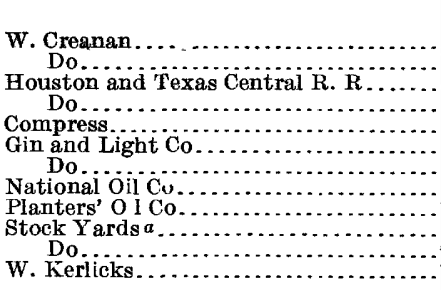 & $\begin{array}{l}\text { Feet. } \\
740 \\
680 \\
720 \\
720 \\
700+ \\
700+ \\
700 \\
715 \\
660 \\
1,020 \\
750 \\
700\end{array}$ & 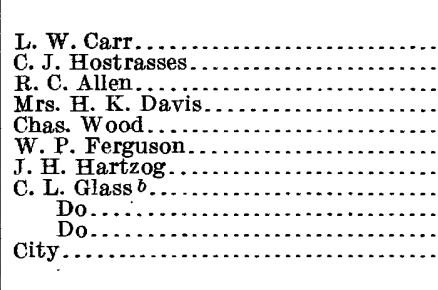 & $\begin{array}{r}\text { Feet. } \\
700 \\
690 \\
666 \\
710 \\
400 \\
720 \\
720 \\
690 \\
700 \\
710 \\
720\end{array}$ \\
\hline
\end{tabular}

$a$ One mile northwest of Hearne.

$b$ Three miles southwest of Hearne.

\section{MILAM COUNTY.}

Shallow wells.-The average depth of shallow wells throughout Milam County is 50 feet. An abundant supply is usually obtained. In the western part of the county considerable difficulty is sometimes experienced in getting a successful well.

Artesian wells.-The International and Great Northern Railroad drilled a 6-inch well at Thorndale to a depth of 2,000 feet, passing through several beds of lignite coal, without obtaining artesian water. Other similar deep borings have been made for artesian water in the western part of the county without success. The following is a list of deep borings in Milam County:

Deep borings in Milam County.

\begin{tabular}{|c|c|c|}
\hline Owner. & Depth. & Location. \\
\hline 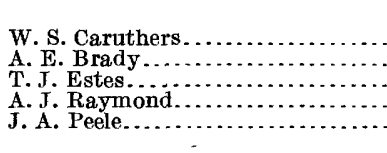 & $\begin{array}{r}\text { Feet. } \\
1,790 \\
1,356 \\
831 \\
700 \\
530\end{array}$ & $\begin{array}{l}\text { Thorndale. } \\
\text { Maysfield. } \\
\text { Baileyville, } 31 \text { miles west. } \\
\text { Branchville. } \\
\text { Branchvile, } 4 \text { miles east. }\end{array}$ \\
\hline
\end{tabular}




\section{BURLESON COUN'TY.}

Shallow wells.-In Burleson County wells 50 to 75 feet deep furnish a good supply of water.

Artesian wells.--Flowing wells are obtained in the Brazos bottom lands at depths varying from 355 to 1,250 feet, the average being about 700 feet. A list of these wells, with other data, the record of a 688-foot well at Clay, and analyses of the water from this well and from one of M. Parker's wells are given below:

Artesian wells in Burleson County.

\begin{tabular}{|c|c|c|c|c|c|}
\hline Owner. & Depth. & $\begin{array}{l}\text { Flow per } \\
\text { minute. }\end{array}$ & $\begin{array}{c}\text { Diame- } \\
\text { ter. }\end{array}$ & Location. & \\
\hline 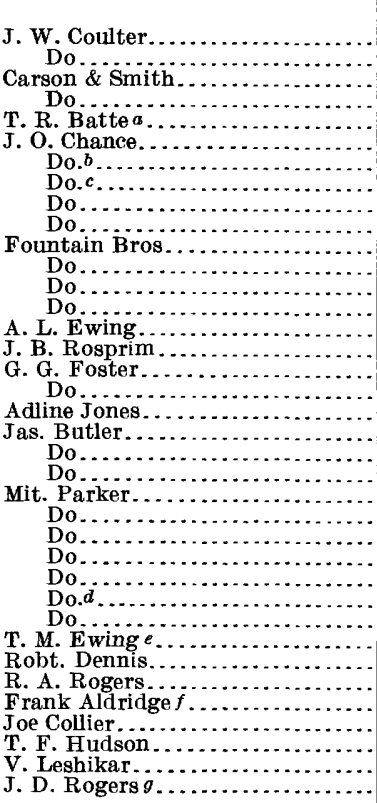 & $\begin{array}{r}\text { Feet. } \\
750 \\
\cdots 355 \\
355 \\
750 \\
850 \\
900 \\
1,009 \\
650 \\
700 \\
550 \\
1,250 \\
900 \\
900 \\
900 \\
740 \\
910 \\
900 \\
900 \\
850 \\
840 \\
900 \\
850 \\
630 \\
585 \\
535 \\
630 \\
835 \\
750 \\
760 \\
511 \\
400 \\
420 \\
760 \\
800 \\
260 \\
180 \\
703\end{array}$ & $\begin{array}{r}\text { Gallons. } \\
10 \\
\text { Small. } \\
5 \\
\text { Strong. } \\
50 \\
1 \frac{1}{2} \\
3 \\
7 \\
\frac{1}{2} \\
\frac{1}{2} \\
20 \\
\frac{1}{2} \\
1 \\
1 \\
2 \\
5 \\
20 \\
25 \\
20 \\
25 \\
25 \\
20 \\
12 \\
12 \\
15 \\
15 \\
35 \\
30 \\
15 \\
2 \\
7 \\
2 \frac{1}{2} \\
2 \\
5 \\
160 \\
\text { Small. } \\
45\end{array}$ & $\begin{array}{c}\text { Inches. } \\
1 \frac{1}{4} \\
1 \\
1 \\
1 \\
1 \frac{1}{4} \\
2 \\
1 \frac{1}{2} \\
3 \\
1 \\
2 \\
2 \\
1 \\
1 \frac{1}{1} \\
1 \frac{1}{4} \\
2 \\
2 \\
2 \\
1 \frac{1}{4} \\
2 \\
2 \\
2 \\
2 \\
1 \\
1 \\
1 \\
1 \\
1 \\
2 \\
2 \\
2 \\
1 \\
1 \\
1 \\
1 \\
6 \\
8 \\
3\end{array}$ & $\begin{array}{l}\text { Clay, } 6 \text { miles northeast. } \\
\text { Clay, } 7 \frac{1}{2} \text { miles northeast. } \\
\text { Clay, } 8 \text { miles northeast. } \\
\text { Do. } \\
\text { Whittaker, } 3 \frac{1}{2} \text { miles southeast. } \\
\text { Whittaker, } 1 \frac{1}{2} \text { miles northeast. } \\
\text { Whittaker. } \\
\text { Whittaker, } 3 \frac{1}{2} \text { miles northwest. } \\
\text { Whittaker, } 4 \frac{1}{2} \text { miles northwest. } \\
\text { Whittaker. } \\
\text { Whittaker, } 1 \frac{1}{2} \text { miles northwest. } \\
\text { Do. } \\
\text { Do. } \\
\text { Myers, } 1 \text { mile southeast. } \\
\text { Myers, } 1 \text { mile south. } \\
\text { Myers. } \\
\text { Myers, } 400 \text { yards west. } \\
\text { Myers, } 800 \text { yards west. } \\
\text { Myers, } 2 \text { miles southwest. } \\
\text { Myers, } 3 \text { miles northwest. } \\
\text { Myers, } 3 \text { miles north. } \\
\text { Grant, } \frac{1}{2} \text { mile south. } \\
\text { Cooks Point, } 3 \text { miles east. } \\
\text { Do. } \\
\text { Pittbridge. } \\
\text { Pittbridge, } 1 \text { mile west. } \\
\text { Pittbridge, } 4 \text { miles south. } \\
\text { Tunis, } 1 \frac{1}{4} \text { miles east. } \\
\text { Tunis, } 3 \text { miles southeast. } \\
\text { Pittbridge, } 1 \frac{1}{4} \text { miles east. } \\
\text { Pittbridge, } 1 \frac{1}{4} \text { miles northeast. } \\
\text { Stone City, } 300 \text { yards south. } \\
\text { Rita, } 7 \frac{1}{2} \text { miles south. } \\
\text { Rita, } 2 \text { miles east. } \\
\text { Caldwel, } \frac{1}{2} \text { mile northeast. } \\
\text { Caldwell, } 5 \text { miles southwest. } \\
\text { Somerville, } 7 \text { miles southeast. }\end{array}$ & \\
\hline
\end{tabular}

a Temperature of water $77^{\circ} \mathrm{F}$; gas escapes from pipe.

$b$ Continuous flow of gas; water salty.

$c$ Gas associated with water.

d At 350 feet a flow of salt water associated with gas was obtained.

$e$ Well flowed 60 gallons a minute at flrst, but is now becoming choked with sand. $f$ Oil well.

$g$ Good flow obtained at 400 feet.

Analysis of water from deep well owned by Mit. Parker, 3 miles southeast of Tunis, Burleson County. $a$

Parts per million.

Potassium (K)

Sodium (Na) $\ldots \ldots \ldots \ldots \ldots$

Magnesium $(\mathrm{Mg}) \ldots \ldots \ldots \ldots \ldots \ldots . \quad 4$

Calcium (Ca) ................ 11

Chlorine $(\mathrm{Cl}) \ldots \ldots \ldots \ldots \ldots \ldots \ldots .64$
Parts per million.

Sulphate radicle $\left(\mathrm{SO}_{4}\right) \ldots \ldots \ldots \ldots 630$

Carbonate radicle $\left(\mathrm{CO}_{3}\right) \ldots \ldots \ldots . .520$

1,756

a Expressed by analyst in grains per gallon and hypothetical combinations; recomputed to parts per million and ionic form at U. S. Geol. Survey. 
Record of well at Clay, Burleson County.

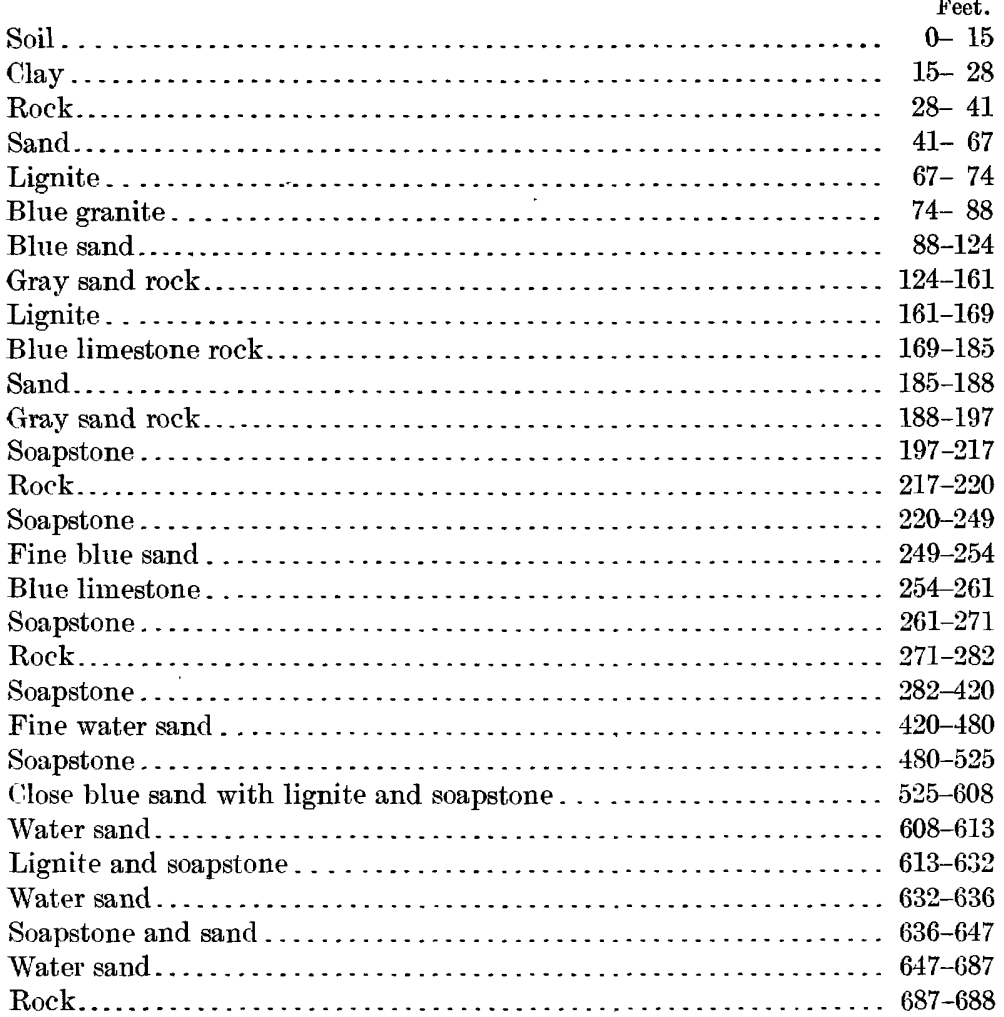

Analysis of water from deep well at Clay, Burleson County. a

\begin{tabular}{|c|c|c|c|}
\hline \multicolumn{2}{|c|}{ "Parts per million. } & \multicolumn{2}{|c|}{ Parts per million. } \\
\hline Sodium (Na) . . . . & 490.0 & Carbonate radicle $\left(\mathrm{CO}_{3}\right) \ldots \ldots \ldots$ & 30.0 \\
\hline Magnesium $(\mathrm{Mg}) .$. & 8.0 & Silica $\left(\mathrm{SiO}_{2}\right) \ldots \ldots \ldots \ldots \ldots \ldots$ & 38.0 \\
\hline Calcium $(\mathrm{Ca}) . .$. . & 21.0 & Organic matter...$\ldots \ldots \ldots \ldots$ & 79.0 \\
\hline Chlorine $(\mathrm{Cl}) \ldots \ldots$. & 490.0 & & \\
\hline Sulphate radicle $\left(\mathrm{SO}_{4}\right) \ldots \ldots \ldots$ & 4.6 & &, 480.6 \\
\hline Bicarbonate radicle $\left(\mathrm{HCO}_{3}\right) \ldots \ldots$ & 320.0 & & \\
\hline
\end{tabular}

\section{BRAZOS COUNTY.}

Shallow wells.-Water in sufficient quantity to supply an ordinary well is found in Brazos County from 35 to 60 feet below the surface.

Artesian wells.-The best developed artesian area in Brazos County is located near Steeles Store and Stone City, between Little and Big Brazos rivers, where about 50 flowing wells are located. About 15 miles southwest of Bryan there are a number of smaller artesian wells, varying in depth from 200 to 1,000 feet, but averaging about 300 feet, with diameters of 1 to 3 inches. The smaller wells yield about

a Expressed by analyst in grains per gallon and hypothetical combinations; recomputed to parts per million and ionic form at U. S. Geol. Survey.

IRR $190-07-5$ 
47 gallons a minute; the larger and deeper ones furnish considerably more. In sinking the deep wells in this district several small flows are encountered before the main water horizon is reached. These are generally cased off and only the water from the lowest horizon allowed to flow. In addition to the above-described wells there are a few in the southern part of the county. A partial list of the artesian and deep wells of Brazos County is given below, also a record of the materials penetrated in the Hearne and Brazos Valley Railroad well at Stone City.

Partial list of artesian and deep wells in Brazos County.

\begin{tabular}{|c|c|c|c|}
\hline Owner. & Depth. & Flow. & Location. \\
\hline 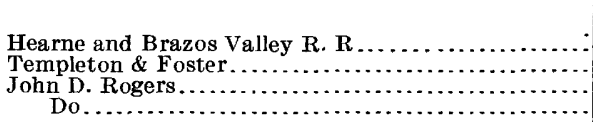 & $\begin{array}{l}\text { Feet. } \\
1,005 \\
900 \\
1,300\end{array}$ & $\begin{array}{l}\text { Flows. } \\
\text { Flows.. } \\
\text { Flows... }\end{array}$ & $\begin{array}{l}\text { Stone City. } \\
\text { Navasota, } 6 \text { miles west. } \\
\text { Allenfarm. } \\
\text { Allenfarm, } 1 \text { mile west. }\end{array}$ \\
\hline
\end{tabular}

Record of Hearne and Brazos Valley Railroad well at Stone City, Brazos County.

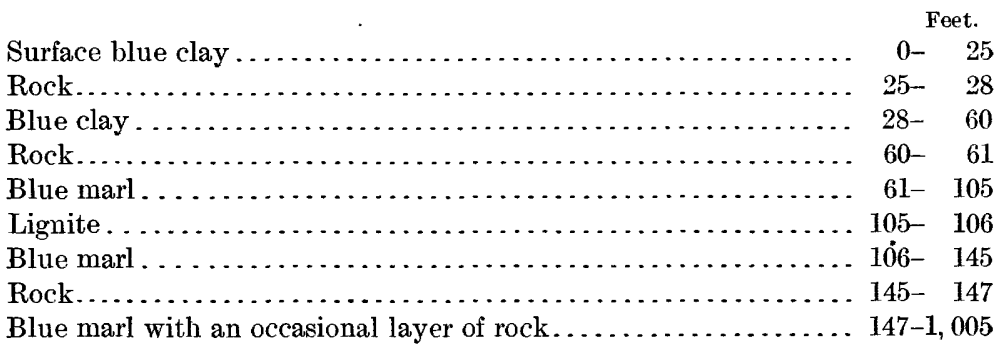

MADISON COUN'TY.

Shallow wells.-Throughout Madison County good water is obtained from wells at depths of 50 to 80 feet, depending on the elevation of the surface.

Artesian wells.-Owing to the ease with which good shallow wells are obtained and the numerous small flowing streams traversing the county, there is little need for flowing wells, and so far as can be ascertained no attempts have been made to develop this resource.

\section{LEON COUNTY.}

Shallow wells.-In Leon County shallow wells vary in depth from 30 to 45 feet, and a good supply of water is generally struck.

Artesian wells.-The only artesian well in Leon County is that owned by J. H. Oliver. It is located one-half mile northwest of Buffalo and has a depth of 1,200 feet. 


\section{FREESTONE COUNTY.}

Shallow wells.-The shallow wells of Freestone County are from 35 to 45 feet deep and generally contain from 6 to 20 feet of water.

Artesian wells. - Owing mainly to the abundant supply of shallowwell water throughout the county, no attempts have been made to get artesian flows.

\section{HOUSTON COUNTY.}

Shallow wells.--Most of the shallow wells throughout Houston County are less than 40 feet deep, and a large supply of water is generally obtained.

Artesian wells.-At Crockett a well was sunk by Prof. J. B. Smith to a depth of 700 feet, and the water rose within 40 feet of the surface. There are several wells at Kenard 1,100 to 1,200 feet deep, from which a large supply of water is obtained by pumping.

\section{ANDERSON COUNTY.}

Shallow wells.-A good water supply is found in Anderson County at a depth of 30 to 40 feet below the surface.

Artesian wells.-There are no artesian wells in this county, but several deep borings have been made at Palestine and other places which furnish a good supply of water by pumping.

\section{LIMESTONE COUNTY.}

Shallow wells.-Water is secured in the southern part of Limestone County at a depth of about 35 feet. In the northwestern part the wells are somewhat deeper, averaging 60 feet.

Artesian wells.-There are no artesian wells in Limestone County, although it is believed that flows might be obtained if wells were sunk to a sufficient depth.

\section{CHEROKEE, TRINITY, ANGELINA, SAN AUGUSTINE, AND SABINE COUNTIES.}

Shallow wells.-Throughout Cherokee, Trinity, Angelina, San Augustine, and Sabine counties shallow wells find water at depths varying from 30 to 50 feet, and the supply is generally large.

Artesian wells.-The only artesian well in these counties is at Groveton, the county seat of Trinity County, where a 6 -inch well 495 feet deep yields 27 gallons a minute. There is a deep well at Bronson, Sabine County, a record of which is given below, also an analysis of the water. 
Record of deep well at Bronson, Sabine County.

Blue clay..................................... 30

Brown shale ................................. $60-103$

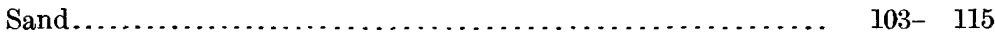

Brown shale.................................... $115-145$

Sand........................................... 1455

Blue clay .................................... 155- 163

Limestone rock................................. 163- 164

Blue clay ...................................... $164-258$

Sand ......................................... 258 272

Blue clay .................................... 322

Brown shale.................................. $322-352$

Blue clay ...................................... $352-374$

Blue clay and "shell" ............................ $374-\quad 380$

Blue clay ...................................... $380-486$

Sand rock............................... 486 . 489

Blue clay ..................................... $489-578$

Blue clay and bowlders........................... 578 586

Blue clay ..................................... $586-674$

Water sand ...................................... $674-729$

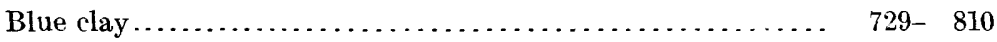

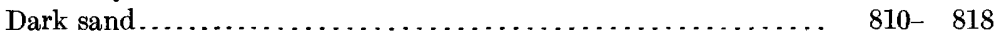

Blue clay..................................... $818-892$

Blue shale and "shell "......................... $892-928$

Dark shale.................................. 928-1,018

Water sand..................................... 1,018-1,068

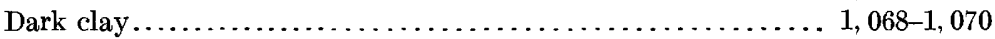

Analysis of water from deep well at Bronson, Sabine County. a

Parts per million.

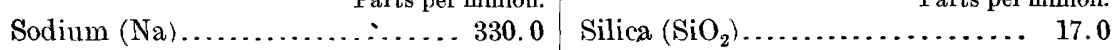

Chlorine $(\mathrm{Cl}) \ldots \ldots \ldots \ldots \ldots \ldots \ldots, 30.0 \quad$ Organic matter................ 34.0

\begin{tabular}{l|l} 
Sulphate radicle $\left(\mathrm{SO}_{4}\right) \ldots \ldots \ldots \ldots$. & 81 \\
Carbonate radicle $\left(\mathrm{CO}_{3}\right) \ldots \ldots \ldots \ldots .395$ & $\overline{814.1}$
\end{tabular}

\section{NACOGDOCHES COUNTY.}

Shallow wells.-Wells of moderate yield are obtained in Nacogdoches County at a depth of 25 feet.

Artesian wells.-Two wells have been sunk in this county and data concerning them are given below.

Artesian wells in Nacogdoches County.

\begin{tabular}{|c|c|c|c|c|}
\hline Owner. & Depth. & $\begin{array}{l}\text { Flow per } \\
\text { minute. }\end{array}$ & $\begin{array}{l}\text { Diame- } \\
\text { ter. }\end{array}$ & Distance from Nacogdoches. \\
\hline $\begin{array}{l}\text { Nacogdoches Ice } \mathrm{Co} \ldots \ldots \ldots \ldots \ldots \ldots \ldots \ldots \ldots \ldots \\
\text { Haywood Lumber } \mathrm{Co} \ldots \ldots \ldots \ldots \ldots \ldots \ldots\end{array}$ & $\begin{array}{r}\text { Feet. } \\
285 \\
820\end{array}$ & \begin{tabular}{c} 
Gallons. \\
\hdashline
\end{tabular} & $\begin{array}{r}\text { Inches. } \\
4 \\
6\end{array}$ & $\begin{array}{l}\frac{1}{1} \text { mile southwest. } \\
1 \text { mile southeast. }\end{array}$ \\
\hline
\end{tabular}

a Expressed by analyst in grains per gallon and hypothetical combinations; recomputed to parts per million and ionic form at U. S. Geol. Survey. 


\section{SHELBY, PANOLA, AND RUSK COUNTIES.}

Shallow wells.--Water in Shelby, Panola, and Rusk counties is obtained in abundance in wells ranging from 20 to 35 feet in depth.

Artesian wells.--There is little demand for artesian water in these counties, owing mainly to the shallow depth at which ground water may be obtained. At Center, Shelby County, there is a deep well, a record of which is given below; also an analysis of the water.

Record log of deep well at Center, Shelby County.

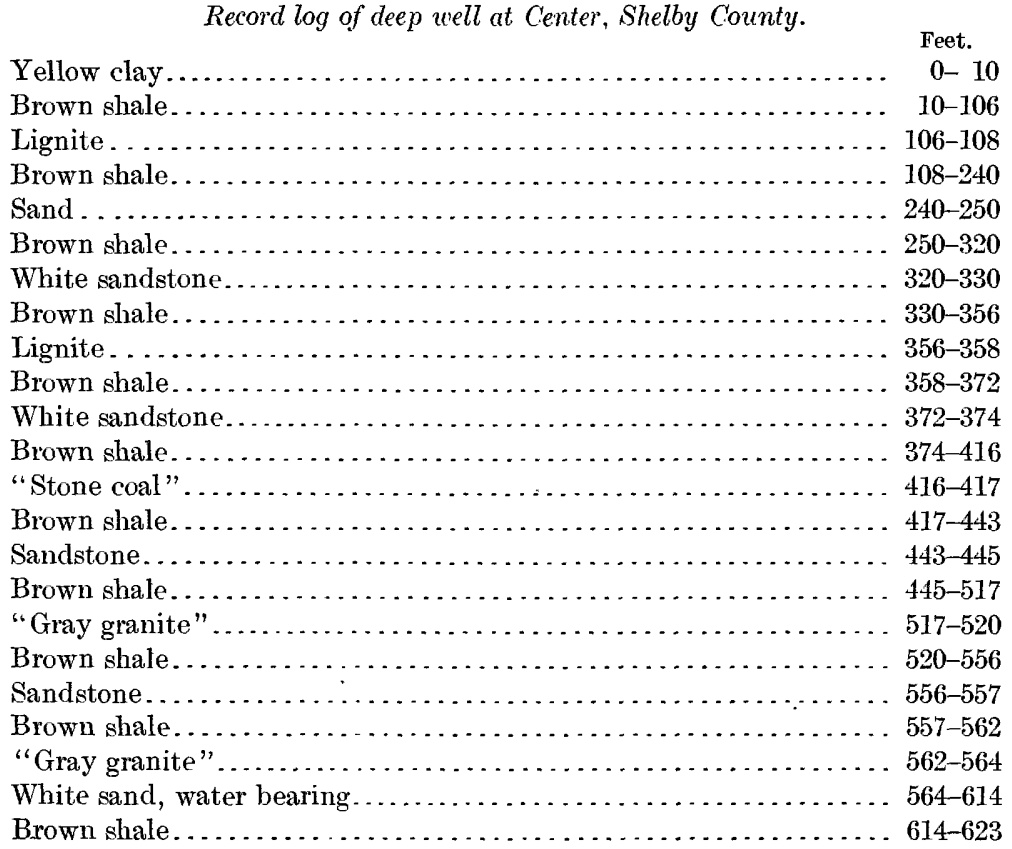

Analysis of water from deep well at Center, Shelby County. ${ }^{a}$

Sodium (Na)

Parts per million.

Calcium (Ca) 370.0

4.1

Chlorine (Cl)

57.0

$\begin{array}{ll}\text { Sulphate radicle }\left(\mathrm{SO}_{4}\right) \ldots \ldots \ldots \ldots & 14.0 \\ \text { Carbonate radicle }\left(\mathrm{CO}_{3}\right) \ldots \ldots \ldots \ldots & 430.0\end{array}$

$\begin{array}{ll}\text { Sulphate radicle }\left(\mathrm{SO}_{4}\right) \ldots \ldots \ldots \ldots & 14.0 \\ \text { Carbonate radicle }\left(\mathrm{CO}_{3}\right) \ldots \ldots \ldots \ldots & 430.0\end{array}$

Parts per million.

Silica $\left(\mathrm{SiO}_{2}\right) \ldots \ldots \ldots \ldots \ldots \ldots \ldots, 24.0$

Organic matter............ 31.0

930.1

\section{VAN ZANIT ANI RAINS COUNTIES.}

Shallow wells. - Throughout Van Zandt and Rains counties an adequate supply of water is obtained from wells ranging in depth from 20 to 45 feet.

Artesian wells.-There are at present no flowing wells in either of these counties; and, so far as can be ascertained, no prospecting for artesian water has been done.

a Expressed by analyst in grains per gallon and hypothetical combinations; recomputed to parts per million and ionic form at U. S. Geol. Survey. 


\section{SMITH COUNTY.}

Shallow wells.-In Snith County water occurs at shallow depths, rarely exceeding 35 feet, and the supply is usually large.

Artesian wells.--A few years ago an oil well was drilled on the county poor farm to a depth of 460 feet and a strong flow of water obtained. No other deep borings have been reported from this county, but it is believed that artesian water could be obtained at other localities if wells were sunk to a sufficient depth.

\section{WOOD AND GREGG COUNTIES.}

Shallow wells.-Water is found in Wood and Gregg counties at depths ranging from 25 to 80 feet. The supply is large and the quality generally good, but a few wells near Quitman and Winnsboro furnish water containing a large percentage of mineral salts.

Artesian wells.--No flowing wells have been reported from either of these counties. About 6 miles south of Longview, Gregg County, an oil well was sunk to a depth of 1,424 feet without obtaining artesian water. It is possible that flows might be found at shallower depths in Wood County or in other parts of Gregg County, but thus far no tests have been made in these localities. A record of the deep oil well near Longview is given below:

\section{Partial record of well 6 miles south of Longview, Gregg County.}

\begin{tabular}{|c|c|}
\hline & $\begin{array}{ll}\text { Feet. } \\
0-285\end{array}$ \\
\hline & $285-305$ \\
\hline & $305-$ \\
\hline e $\ldots \ldots \ldots \ldots, \ldots, \ldots$, & $307-$ \\
\hline 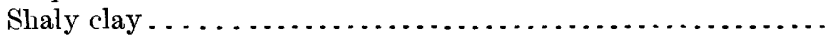 & $322-$ \\
\hline & 329 \\
\hline$\cdots$ & $353-$ \\
\hline 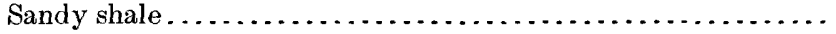 & $356-$ \\
\hline & $437-$ \\
\hline & $452-$ \\
\hline & $487-$ \\
\hline$\cdots \cdot \cdots$ & 489 \\
\hline ....... & $543-$ \\
\hline (2 & $545-$ \\
\hline , & $551-$ \\
\hline 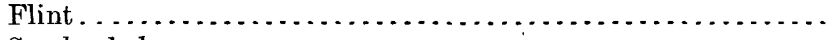 & $571-$ \\
\hline (n... & $574-$ \\
\hline (n. & 710 \\
\hline ..... & $745-$ \\
\hline ind . & $756-$ \\
\hline & $780-$ \\
\hline & $880-$ \\
\hline 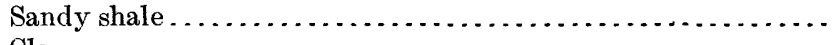 & $892-$ \\
\hline &, $027-$ \\
\hline & 34- \\
\hline 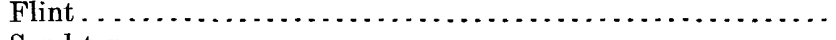 & $1,199-1,20$ \\
\hline & \\
\hline & \\
\hline
\end{tabular}




\section{UPSHUR COUNTY.}

Shallow wells.--In Upshur County the water table appears to be about 35 to 40 feet below the surface, and at this depth a good supply of relatively pure water is obtained.

Artesian wells.-The only artesian well which has been reported from this county is" on the John Gillis ranch, $1 \frac{1}{2}$ miles southwest of Hawkins. It is 250 feet deep and yields a flow of $2 \frac{1}{2}$ gallons a minute.

\section{HARRISON COUNTY.}

Shallow wells.-In Harrison County sufficient water for ordinary domestic purposes is struck at depths rarely exceeding 40 feet, and the quality is usually good.

Artesian wells. - The only artesian well in Harrison County is owned by the Marshall waterworks. This well was bored in January, 1900, and the first flows were obtained at shallow depths. It is 208 feet deep, 6 inches in diameter, and has a flow of 200,000 gallons every twenty-four hours. The following is a record of the material penetrated:

Record of artesian well at Marshall, Harrison County.

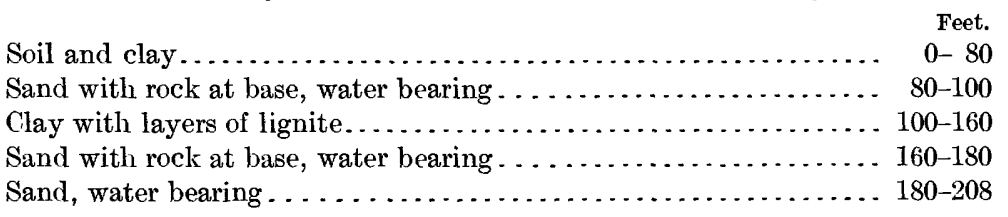

This test well was made without a strainer, and considerable sand was brought up with the water. The test was continued for about twelve hours with no apparent change of flow.

\section{MARION COUNTY.}

Shallow wells.-Water in Marion County is found at 25 to 50 feet below the surface, and the supply is both abundant and pure.

Artesian wells.-The only artesian well reported from this county is owned by J. M. De Ware, at Jefferson. It is 2 inches in diameter, 801 feet deep, and yields a small flow, but the exact amount has not been ascertained. 



\section{INDEX.}

A.

Acknowledgments to those aiding.-. Alameda, wells near._._. Alligator Head, well at, record of

Alta Loma, wells at. wells at, record of

Alvin, wells near.

Anahuac, wells at and near.

Anaqua, wells near..............

Anderson County, artesian wells in. shallow wells in

Angelina County, artesian wells in _shallow wells in

Arcola, well near.

Area of region

Aransas County, artesian wells in shallow wells in

Arnold well, record of

Artesia, wells near. location of, map showing. occurrence of ......................... views of

Atacosa County, artesian wells in shallow wells in

Atravesada well, record of ........

Ashby, well near.

Austin County, artesian wells in shallow wells in

\section{B.}

Barker, well near

Barosa Creek, well on, record of

Bastrop, well near

Bastrop County, artesian wells in shallow wells in

Batesville, wells near...........

Bay City, wells near.

Bay View, well near...............

Beasley (S. H.) well, record of _...-

Beaumont, well at _.............

Bee County, artesian wells in shallow wells in

Pexar County, artesian wells in shallow wells in _._. $\mathbf{5 3}$

Blessing, wells near

Bobbin, well at, record of well at, water of, analysis of _- 45

Branchville, wells at and near....... 59

Prazoria, well near............. 21

Brazoria County, artesian wells in $21-24$ artesian wells in, records of _. $22-24$ shallow wells in

21
Brazos, wells near

Brazos County, artesian wells in _.- 61-62 artesian wells in, recold of _. 62 shallow wells in

Brenham, watei supply of _._._._. 41

Breslau, well at

Bronson, well at, record of _..._. 63-64 well at, water of, analysis of ${ }_{--} \quad 64$

Brown (H. G.) well, record of __- $\mathbf{3 5}$

Brownsville, wells at_._._._._. 3

Pruniville, wells at _._. 51

Bryan, wells near.

Iryan Heights, well near__._._. 21

Buffalo, well near._. 62

Burleson County, artesian wells in $60-61$ artesian well in, record of _._ 61 water of, analyses of _...- 60,61 shallow wells in

C.

Caldwell, wells near._. 60

Caldwell County, artesian wells in $\quad 58$ shallow wells in

Calhoun County, artesian wells in $14-15$ artesian wells in, record of _._- 15 shallow wells in

Call, well near._._.

Calvert, wells near.

Cameron County, artesian wells in $3-6$ artesian wells in, records of -.- 5-6 shallow wells in .......... 3

Carancohue, wells near......... 16

Carrizo Springs, wells near._._._. 51-52

Cedar Bayou, wells at

Center, well at, record of well at, water of, analysis of _- 65

Chambers County, artesian wells in $30-31$ shallow wells in

Chapel Hill, wells near.

Cherokee County, artesian wells in $\quad 63$ shallow wells in 63

Chesterville, artesian wells near irrigation near._... 3

Clay, wells at wells at, lecord of water of, analysis of _..._ 61

Cleveland, well at, record of well at, water of, analysis of _. $\quad 44$

Clodine, wells at ................ 24

Colorado County, artesian wells in.. 40 artesian wells in, record of _..- 40 shallow wells in Columbia, wells near _._._._. 21 Columbus, well at, record of 
Page.

Conroe, well at, record of well at, water of, analysis of

Cooks Point, wells near.

Corpus Christi, elevation at

Cotulla, wells near

Counties, underground water in, description of _........

Courtney, wells near.

Cretaceous rocks, occurrence of _...-

Crockett, well at

Cuero, well near, record of

Cunningham farm, wells on

D.

Damon mound, well at

Davenport, well at

Deepwater, wells at _............

Deerpark, wells at

Derby, wells at and near.........

Dewet, wells at and near

Dewitt County, artesian wells in artesian wells in, record of .... shallow wells in.

Dickinson, wells at and near......

Dies, well at well at, record of water of, analysis of

Dimmit County, artesian wells in artesian wells in, record of shallow wells in

Double Bayou, wells at and near

Drainage, sketch of

Duval County, artesian wells in shallow wells in

E.

Eagle Lake, wells near

Wast Bernard, artesian wells near.irrigation near

Teho, wells at and

Edgewater, well at

Edna, wells near.

Fil Campo, artesian wells near irrigation near

Elevations, range of

Lncinal, well at

Fngle, wells near

Grin, wells at

\section{F.}

Falfurrias, wells near.

Fayette County, artesian wells in shallow wells in

Floresville, wells near

Fort Bend County, deep wells in shallow wells in.

Freestone County, artesian wells in shallow wells in

Frio County, artesian wells in shallow wells in view of

Frio River, wells on
$45-46$
G.

Page.

Galveston, water supply of well at record of -

Galveston County, artesian wells in $-27-30$ artesian wells in, records of $\ldots$... $28-30$ shallow wells in

Galveston well, record of _._._. 12

Genoa, wells at and near._._._ 25

Gentry (Charles) well, record oí_-- $37-38$

Geography, sketch of __._._. 1-2

Geology, sketch of

Gillis (John) ranch, well on_...- 67

Goball, well at___._. 41

Goliad, well near

Goliad County, artesian wells in ... 34 shallow wells in $\quad 34$

Gonzales, well near, record of _.... 37

Gonzales County, artesian wells in _. $35-38$ artesian wells in, record of $\ldots-\ldots 37-38$ shallow wells in

Grant, well near. 60

Gregg County, artesian wells in _.. $\quad 66$ artesian wells in, record of _._ $\quad 66$ shallow wells in

Grimes County, artesian wells in_.- 42 artesian wells in, record of _._ 42 water of, analysis of _..._ 42 shallow wells in

Groveton, well at

Guadalupe County, artesian wells in $\quad 57$ shallow wells in

H.

Hallettsville, wells at and near_.__ 38

Hampshire, wells near._-___._. 31

Hardin County, artesian wells in _- $47-48$ artesian wells in, records of _-- 47,48 water of, analyses of shallow wells in

Harris County, artesian wells in $--24-27$ artesian wells in, record of _-_- $26-27$ shallow wells in

Harrisburg, well near._._._. 25

Harrison County, artesian wells in $\quad 67$ artesian wells in, record of ... 67 shallow wells in _._._._. 67

Hawkins, well near._._._. 67

Hawkinsville, well near._._._._. 19

Hidalgo County, artesian wells in $-7-8$ artesian wells in, records of -- 7 water of, analysis of _..._- 8 shallow wells in

Hearne, wells near._.___._. 58

Hempstead, wells at and near._-_. . 41

Hitchcock, wells near._._._._. 29

Hoskins Mound, well at, record of

Houston, water supply of wells at record of _._.

Houston County, artesian wells in _- 63 shallow wells in _.......... 63

Humble, well at 
I.

Inez, well near

Irrigation, use of

\section{J.}

Jackson County, artesian wells in -- 16-18 artesian wells in, records of _-_ 17-18 shallow wells in

Jasper County, artesian wells in artesian wells in, records of _-_ 49-50 water of, analysis of _._-_._. 50 shallow wells in _._._....... 48

Jeffer'son, well at

Jefferson County, artesian wells in 3 31-32 artesian well in, record of shallow wells in

K.

Karnes City, well at

Karnes County, artesian wells in shallow wells in

Katy, wells at

Kenard, wells near.

Kenedy Pasture Company"s wells, list of -.................

Kemper, wells near

King ranch, wells on wells on, water of, analysis of

Kirbyville, well at well at, record of water of, analysis of

\section{L.}

La Porte, wells at and near

Lasalle County, artesian wells in.-shallow wells in

Lasater (E. C.) ranch, wells on wells on, waters of, analyses of_-

Lau reles ranch, wells on

Lavaca County, artesian wells in shallow wells in

League City, wells at

Lee County, artesian wells in shallow wells in

I.eesville, wells near.

I.eobau, well near.

Leon county, artesian wells in shallow wells in

I,eon Springs, wells at

Liberty, wells at and near

Liberty County, artesian wells in artesian wells in, records of water of, analyses of shallow wells in

Limestone County, artesian wells in shallow wells in.

Live Oak County, artesian wells in shallow wells in

Location of region

Lockhart, wells near.

Longview, well at, record of

\section{M.}

McMullen County, artesian wells in shallow wells in
Madison County, artesian wells in shallow wells in

Manvel, well near._................

Marion County, artesian wells in shallow wells in

Markham, well near-

Mar'shall, well at

Martindale, wells near

Tatagorda, well near"-

Matagorda County, artesian wells in shallow wells in

Maverick County, artesian wells in $\quad 51$ shallow wells in

Maxwell, wells near_._._._._._. 57

Maysfield, well at_____._._. $\quad 59$

Meadow Brook County farms, wells on

Mesquite well, water of, analysis of

Midfield, well near._._. 19

Miguel, wells near._... 54

Mikesha. well near._._._. 34

Milam County, artesian wells in_--_ $\quad 59$ shallow wells in

Montgomery County, artesian wells in _............ $44-46$ artesian wells in, records of water of, analyses of _._._- $45-46$ shallow wells in

Morgan Point, wells at__..._._. 25

Mount Belvieu, wells at and near-_. $\quad 31$

Myers, wells at and near._._._ 60

\section{N.}

Nacogdoches. wells near._._._-_--

Nacogdoches County, artesian wells in 64 shallow wells in 64 Navasota well, record of _..._. $4^{\circ}$ water of, analysis of _._._._. 42

Newton County, artesian wells in_- 50 shallow wells in

Nueces County, artesian wells in _. 9-13 artesian wells in, records of _-_ 10-12 waters of, analyses of _..- 12-13 shallow wells in

\section{O.}

Oakhurst, well at_________- 46 Oakville, wells at and near._._._. 34

O'Donnell (J. H.) farm, wells at_--_ 24

Orange, wells at and near._._._. $32-33$

Orange County, artesian wells in__- $32-33$ shallow wells in__._._._. 32

Orejas well, record of

P.

Palacios, wells at_______._. 19

Palestine, wells at_________ 63

Panola County, artesian wells in _- $\quad 65$ shallow wells in

Parker (Mit.) well, water of, analysis of - 60

Pasadena, wells at_... 25

Pearsall, well near, view of wells near _...... 54 
P'ierce Station, well at, record of I'ittsbridge, wells at and near.

l'leasanton, wells near.

Point Lavaca, wells near ......... I'olk County, artesian wells in shallow wells in

Irort Arthur, well at_._._. l'raha, wells at

Q.

Quintana, well near.

\section{R.}

lains County, artesian wells in shallow wells in

liancho, wells near.

Refugio County, artesian wells in shallow wells in

Rice, irrigation for

Richmond, water supply of well at

Rio Grande embayment, wells in wells in, plate showing

lita, wells near..............

Robertson County, artesian wells in $58-59$ shallow wells in

lausk County, artesian wells in shallow wells in

s.

Sabine county, artesian wells in $\ldots$-. $69-64$ artesian wells in, record or'..... water of, analysis of-_... shallow wells in

Sabine pass, well at ............... well at. record of

San Antonio, water supply o: wells at and near.

San Augustine County, artesian wells in shallow wells in

San Jacinto County, artesian wells in shallow wells in

San Miguel Creek, wells or......

San Patricio County, artesian wells in shallow wells in

Sandy Point, well near............ Santa Clara well, recold of

Sauz ranch, wells at and near, records of

Schulenburg, wells at Seabrook, wells at and near._.....Seeligson ranch, wells on wells on, record of water of, analysis of ......

Seguin, well near._._._.

Shelby County, artesian wells in artesian wells in, record of _... water of, analysis of shallow wells in

Shiner. wells at and near
Page. well at, record of water of, analysis of

Smith County, artesian wells in _._ $\quad 66$ shallow wel]s in

Somerville, well near._______ 60

Starr County, artesian wells in artesian wells in, water of, anal$y$ sis of shallow wells in

Steeles store. well near

Stıckdale, well near._._._._. 57

Stone City, well at and near _._ 61), 61, 6: Stowell, well near._._._. 31

Strange, wells at

Streams, chatacter of

Stribling well, record of _._....... 32

Sugar Land, wells near._._._._. 24

Sullivan (D.) ranch, wells on .... T

Surfside, wells near._____._.

Sutherland Springs, well near._._- 57

\section{T.}

Tertiary rocks, occurrence of _._._ 2

Texas city. wells at________ 29

Texas Land and Cattle Company's ranch, wells on

Thorndale, well at

Tilden, wells at and near..... 54

Topographs, sketch of _._._. 2

Trinity River, well at, record of well at, water of, analysis of __ $\quad 43$

Tunis, well near, water of, analysis of

Tyler County, artesian wells in_... 48 shallow wells in 48

\section{I.}

Underground water, description of, by counties ........ 3-67

Union, well near._. 57

Upshur County, artesian wells in $\quad 67$ shallow wells in

\section{v.}

Van Zandt County, artesian wells in shallow wells in Vanraub, wells near._..........

Victoria, well at and neap

Victoria County, artesian wells in $15-16$ shallow wells in

Votaw, well at well at, record of water of, analysis of _._. 48

W.

Wadsworth, well near._._......

Walker County, artesian wells in

Waller County, artesian wells in 
Waller County, shallow wells in

Waller, well near

Wallisville, well at

Ward and Russell ranch, wells on--

Washington, well at

Washington County, artesian wells in shallow wells in

Water, underground, description of, by counties importance of

Webb County, artesian wells in shallow wells in

Webster, artesian wells near._...irrigation near wells at and near

Wells, artesian, flow of location of, map slowing. occurrence of views of

Wharton County, artesian wells in artesian wells in, record of sliallow wells in
Page.
White Sulphur well, water of, analysis of

Whittaker, wells at and near...... Wiess and Sander's ranch, wells on wells on, records of

Page.

Wiess Bluff, well near._._._. 48

Wilson County, artesian wells in _._ $\quad 57$ shallow wells in____.___._. 57

Wood County, artesian wells in_.-- $\quad 66$ shallow wells in

Woodville, well near._._._... 48

Wooster, well near____._._._. 25

Wrightsboro, wells near._._._._. $35-36$

Y.

Yoakum, well at

Yorktown, wells at

Z.

Zapata County, artesian wells in_-- 33 shallow wells in

Zavalla County, artesian wells in -52 shallow wells in 


\section{CLASSIFICATION OF THE PUBLICATIONS OF THE UNITED STATES GEOLOGICAL SURVEY.}

[Water-Supply Paper No. 190.]

The publications of the United States Geological Survey consist of (1) Annual Reports, (2) Monographs, (3) Professional Papers, (4) Bulletins, (5) Mineral Resources, (6) Water-Supply and Irrigation Papers, (7) Topographic Atlas of United States-folios and separate sheets thereof, (8) Geologic Atlas of United States-folios thereof. The classes numbered 2, 7, and 8 are sold at cost of publication; the others are distributed free. A circular giving complete lists can be had on application.

Most of the above publications can be obtained or consulted in the following ways:

1. A limited number are delivered to the Director of the Survey, from whom they can be obtained, free of charge (except classes 2,7 , and 8 ), on application.

2. A certain number are delivered to Senators and Representatives in Congress for distribution.

3. Other copies are deposited with the Superintendent of Documents, Washington, D. C., from whom they can be had at prices slightly above cost.

4. Copies of all Government publications are furnished to the principal public libraries in the large cities throughout the United States, where they can be consulted by those interested.

The Professional Papers, Bulletins, and Water-Supply Papers treat of a variety of subjects, and the total number issued is large. They have therefore been classified into the following series: A, Economic geology; B, Descriptive geology; C, Systematic geology and paleontology; D, Petrography and mineralogy; E, Chemistry and physics; F, Geography; G, Miscellaneous; H, Forestry; I, Irrigation; J, Water storage; K, Pumping water; L, Quality of water; M, General hydrographic investigations; N, Water power; $\mathrm{O}$, Underground waters; $\mathrm{P}$, Hydrographic progress reports. This paper is the sixty-seventh in Series $O$, the complete list of which follows: ( $P P=$ Professional Paper; $B=$ Bulletin; WS $=$ Water-Supply Paper):

SERIES O, UNDERGROUND WATERS.

WS 4. A reconnaissance in southeastern Washıngton, by I. C. Russell. 1897. 96 pp., 7 pls. (Out of stock.)

WS 6. Underground waters of southwestern Kansas, by Erasmus Haworth. 1897. 65 pp., 12 pls. (Out of stock)

WS 7. Seepage waters of northern Utah, by Samuel Fortier. 1897.50 pp., 3 pls. (Out of stock.)

WS 12. Underground waters of southeastern Nebraska, by N. H. Darton. 1898. 56 pp., 21 pls. (Out of stock.)

WS 21. Wells of northern Indiana, by Frank Leverett. 1899. $82 \mathrm{pp}, 2$ pls. (Out of stock.)

WS 26. Wells of southern Indiana (continuation of No, 21), by Frank Leverett. 1899. 64 pp. (Out of stock.)

Ws 30. Water resources of the Lower Peninsula of Michigan, by A. C. Lane. 1899. 97 pp., 7 pls. (Out of stoek.)

WS 31. Lower Michigan mineral waters, by A. C. Lane. 1899. 97 pp., 4 pls. (Out of stock.)

WS 34. Geology and vater resources of a portion of southeastern South Dakota, by J. E. Todd. 1900. 34 pp., 19 pls.

WS 53. Geology and water resources of Nez Perces County, Idaho, Pt. I, by 1, C. Russell. 1901. 86 pp., 10 pls. (Out of stock.)

WS 54. Geology and water resources of Nez Perces County, Idaho, Pt. II, by I. C. Russell. 1901. 87-141 pp. (Out of stock.) 
WS 55. Geology and water resources of a portion of Yakima County, Wash., by G. O. Smith. 1901. 68 pp., 7 pls. (Out of stock.)

WS 57. Preliminary list of deep borings in the United States, Pt. I, by N. H. Darton. $1902.60 \mathrm{pp}$. (Out of stock.)

WS 59. Development and application of water in southern California, Pt. I, by J. B. Lippineott. 1902. 95 pp., 11 pls. (Out of stock.)

WS 60. Development and application of water in southern California, Pt. II, by J. B. Lippincott. 1902. 96-140 pp. (Out of stock.)

WS 61. Preliminary list of deep borings in the United States, Pt. II, by N. H. Durton. 1902. 67 pp. (Out of stock.)

WS 67. The motions of underground waters, by C. S. Slichter. 1902. 106 pp., 8 pls. (Out of stock.)

B 199. Geology and water resources of the Snake River Plains of Idaho, by I. C. Russell. 1902.192 pp., 25 pls.

WS 77. Water resources of Molokai, Hawaiian Islands, by Waldemar Lindgren. $1903.62 \mathrm{pp.,} 4 \mathrm{pls.}$

WS 78. Preliminary report on artesian basins in southwestern Idaho and southeastern Oregon, by I. C. Russell. 1903. 53 pp., 2 pls.

PP 17. Preliminary report on the geology and water resources of Nebraska west of the one hundred and third meridian by N. H. Darton. $1903.69 \mathrm{pp} ., 43 \mathrm{pls}$.

Ws 90. Geology and water resources of a sart of the lower James River Valley, South Dakota, by J. E. Todd and C. M. Hall. $1904.47 \mathrm{pp} ., 23 \mathrm{pls}$.

WS 101. Underground waters of southern Louisiana, by G. D. Harris, with discussions of their uses for water supplies and for rice irrigation, by M. L. Fuller. 1904. 98 pp., 11 pls.

WS 102. Contributions to the hydrology of eastern United States, 1903, by M. L. Fuller. 1904. 522 pp.

WS 104. Underground waters of Gila Valley, Arizona, by W. T. Lee. $1904.71 \mathrm{pp}, 5 \mathrm{pls}$.

WS 106. Water resources of the Philadelphia district, by Florence Bascom. 1904. 75 pp., 4 pls.

WS 110. Contributions to the hydrology of eastern United States, 1904; M. L Fuller, geologist in charge. 1904. 211 pp., 5 pls.

PP 32. Geology and underground water resources of the central Great Plains, by N. H. Darton. 1904. 433 pp., 72 pls. (Out of stock.)

WS 111. Preliminary report on underground waters of Washingtor by Henry Landes. 1904. 85 pp., $1 \mathrm{pl}$.

Ws 112. Underflow tests in the drainage basin of Los Angeles River, by Homer Hamlin. 1904. 55 pp., 7 pls.

WS 114. Underground waters of eastern United States, by M. L. Fuller, geologist in charge, 1904. 285 pp., 18 pls.

WS 118. Geology and water resources of east-central Washington, by F. C. Calkins. 1905. 96 pp., 4 pls.

B 252 Preliminary report on the geology and water resources of central Oregon, by I. C. Russell. 1905. 138 pp., 24 pls.

Ws 120. Biblographic review and index of papers relating to underground waters published by the United States Geological Survey, 1879-1904, by M. L. Fuller. 1905. 128 pp.

WS 122. Relation of the law to underground waters, by D. W. Johnson. 1905 . 55 pp.

WS 123. Geology and underground water conditions ot the Jornada del Muerto, New Mexico, by C. R. Keyes. $1905.42 \mathrm{pp} .9 \mathrm{pls}$.

WS 136. Underg roundwaters of the Salt River Valley, by W. T. Lee. 1905.194 pp., 24 pls.

B 264. Record of deep-well drilling for 1904, by M. L. Fuller, E. F. Lines, and A. C. Veateh. 1905. $106 \mathrm{pp}$.

PP 44. Underground water resources of Long Island, New York, by A. C. Veatch and others. 1905. 394 pp., 34 pls.

WS 137. Development of underground waters in the eastern coastal plain region of southern California, by W. C. Mendenhall. 1905. 140 pp., 7 pls.

WS 138. Development of underground waters in the central coastal plain region of southern California, by W. C. Mendenhall. $1905.162 \mathrm{pp} ., 5 \mathrm{pls}$.

WS 139. Development of underground waters in the western coastal plain region of southern California, by W. C. Mendenhall. $1905.105 \mathrm{pp} ., 7 \mathrm{pls}$.

WS 140. Field menasrements of the rate of movemen of underground waters, by C. S. Slichter. 1905. 122 pp., 15 pls.

WS 141. Observations on the ground waters of Rio Grande Valley, by C. S. Slichter. 1905, 83 pp., - 5 pls.

WS 112. Hydrology of San Bernardino Valley, California, by W. C. Mendenhall. 1905. 124 pp., 13 pls.

W 145. Contributions to the hydrology of eastern United States; M. L. Fuller, geologist in charge. 1905. 220 pp., 6 pls.

WS 148. Geology and water resources of Oklahoma, by C. N. Gould. 1905.178 pp., 22 pls.

WS 149. Preliminary list of deep borings in the United States, second edition, with additions, by N. H. Darton. 1905. 175 pp.

PP 46. Geology and underground water resources of northern Louisiana and southern Arkansas, by A. C. Veatch. 1906,122 pp., 51 pls.

WS 153. The underflow in Arkansas Valley in western Kansas, by C. S. Slichter. 1906.90 pp., 3 pls. 
WS 154. The geology and water resources of the eastern portion of the Panhandle of Texas, by $\mathrm{C} . \mathrm{N}$. Gould. $1906.64 \mathrm{pp} ., 15 \mathrm{pls}$.

WS 155. Fluctuations of the water level in wells, with special reference to Long Island, New Iork, by A. C. Veatch. $1906.83 \mathrm{pp} ., 9 \mathrm{pls}$.

WS 157. Underground water in the valleys of Utah Lake and Jordan River, Utah, by G. B. Richardson. 1906. $81 \mathrm{pp},, 9 \mathrm{pls}$.

Ws 158. Preliminary report on the geology and underground waters of the Roswell artesian area, New Mexico, by C. A Fisher. 1906. 29 pp., 9 pls.

PP 52. Geology and underground waters of the Arkansas Valley in eastern Colorado, by N. H. Darton. 1906. 90 pp., 28 pls.

WS 159. Summary of underground-water resources of Mississippi, by A. F. Crider and L. C. Johnson. 1906. $86 \mathrm{pp} ., 6 \mathrm{pls}$.

PP 53. Geology and water resources of the Bighorn basin, Wyoming, by C. A. Fisher. $1906.72 \mathrm{pp.}$ $16 \mathrm{pls}$.

WS 160. Underground-water papers, 1906, by M. L. Fuller, 1906. 104 pp., 1 pl. (Out of stock.)

WS 163. Bibliographic review and index of underground-water literature published in the United States in 1905, by M. L. Fuller, F. G. Clapp, and B. L. Johnson. 1906. 130 pp.

WS 164. Underground waters of Tennessee and Kentucky west of Tennessee River and of an adjacent area in Illinois, by L. C. Glenn. $1906.173 \mathrm{pp} ., 7 \mathrm{pls}$.

WS 181. Geology and water resources of Owens Valley, California, by W. T. Lee. 190628 pp., 6 pls. (Out of stock.)

WS 182. Flowing wells and municipal water supplies in the southern portion of the Southern Peninsula of Michigan, by Frank Leverett and others. $1906.292 \mathrm{pp} ., 5 \mathrm{pls}$.

WS 183. Flowing wells and municipal water supplies in the middle and northern portions of the Southern Peninsula of Michigan, by Frank Leverett and others. $1906.393 \mathrm{pp} ., 5 \mathrm{pls}$.

B 298. Record of deep-well drilling for 1905, by M. L. Fuller and Samuel Sanford. $1906.299 \mathrm{pp}$.

WS 184. The underflow of the South Platte Valley, by C. S. Slichter and H. C. Wolff. 1906. $42 \mathrm{pp}$.

WS 188. Water resources of the Rio Grande Valley in New Mexico and their development, by W. T. Lee. $1906.59 \mathrm{pp} ., 10 \mathrm{pls}$.

WS 190. Underground waters of Coastal Plain of Texas, by T. U. Taylor. 1907. 73 pp., 3 pls.

The following papers also relate to this subject: Underground waters of Arkansas Valley in eastern Colorado, by G. K. Gilbert, in Seventeenth Annual, Pt. II; Preliminary report on artesian waters of a portion of the Dakotas, by N. H. Darton, in Seventeenth Annual, Pt. II; Water resources of Illinois, by Frank Leverett, in Seventeenth Annual, Pt. II; Water resources of Indiana and Ohio, by Frank Leverett, in Eighteenth Annual, Pt. IV; New developments in well boring and irrigation in eastern South Dakota, by N. H. Darton, in Eighteenth Annual, Pt. IV; Rock waters of Ohio, by Edward Orton, in Nineteenth Annual, Pt. IV; Artesian-well prospects in the Atlantic coastal plain region, by N. H. Darton, Bulletin No. 138.

Correspondence should he addressed to

The Director,

United States Geological Survey, W ASHINGTON, D. C.

APRIL, 1907.

1RR $190-07 \longrightarrow 6$ 